
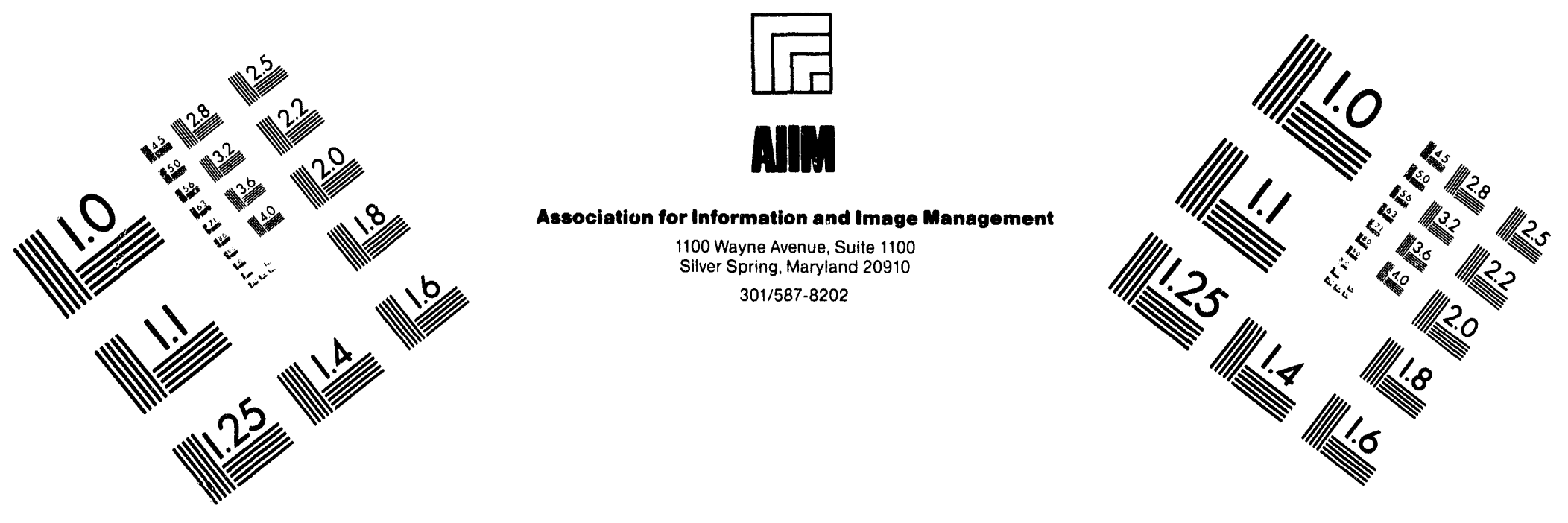

\title{
Centimeter
}

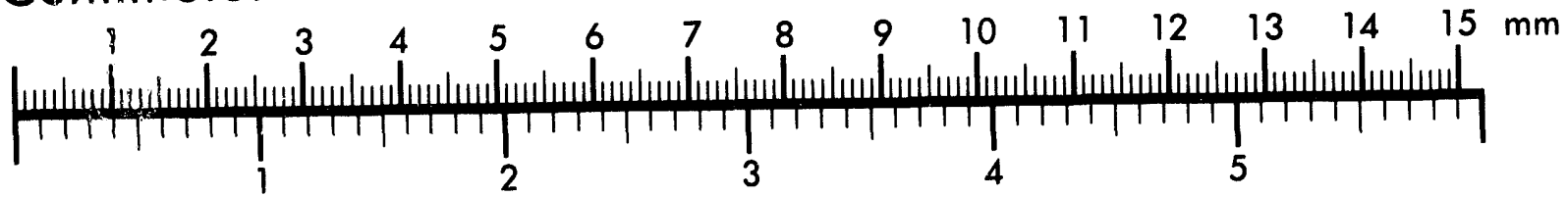

Inches
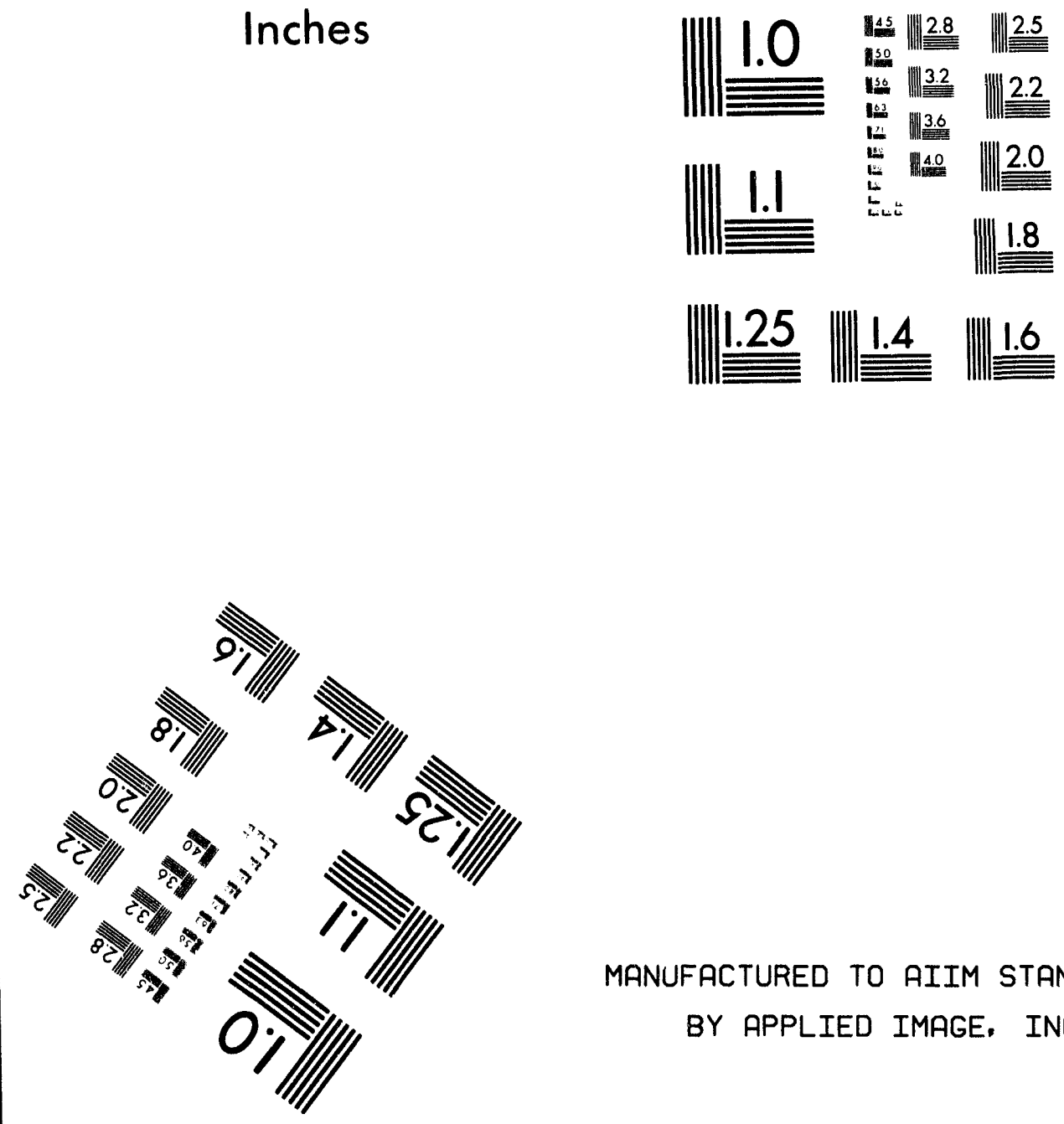

MANUFACTURED TO AIIM STANDARDS

BY APPLIED IMAGE. INC.

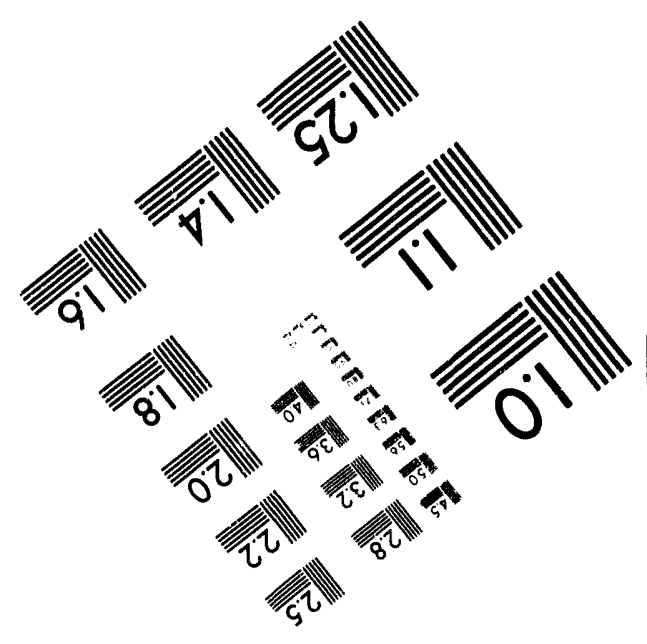



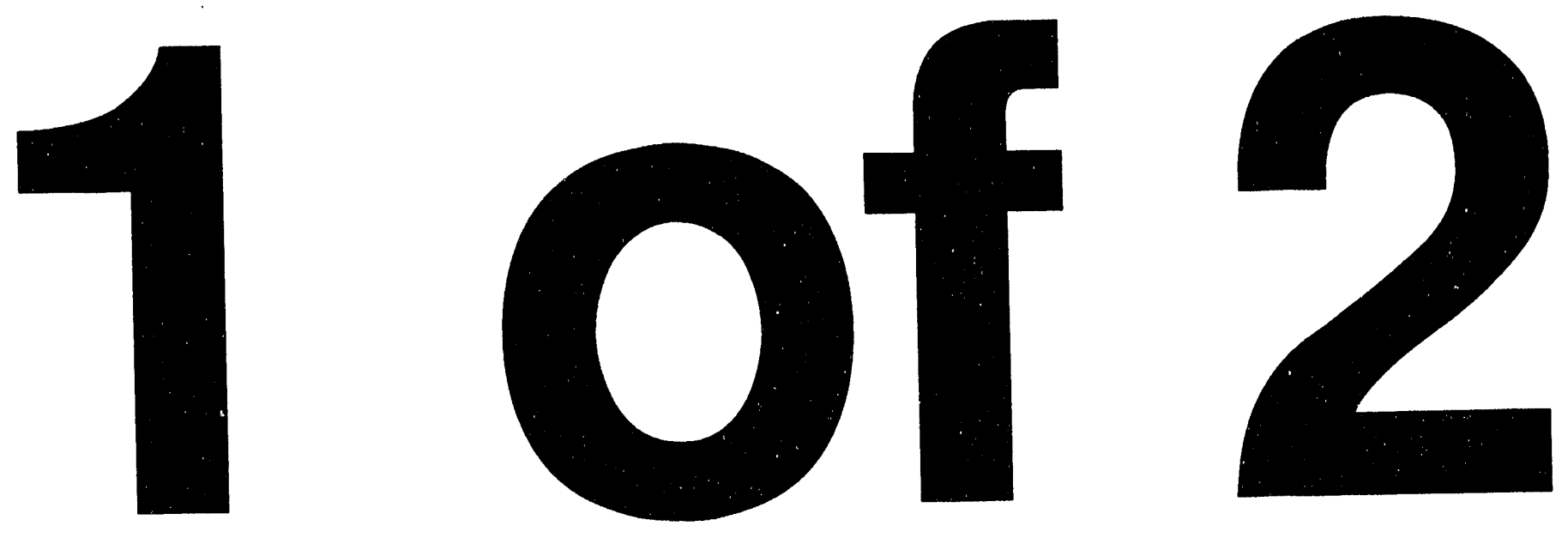


\section{Synergies and Conflicts in Multimedia Pollution Control Related to Utility Compliance with Title IV of the Clean Air Act Amendments of 1990}

by K.A. Bailey, A.P. Loeb, J.W. Formento, and D.W. South

Policy and Economic Analysis Group,

Decision and Information Sciences Division,

Argonne National Laboratory, 9700 South Cass Avenue, Argonne, Illinois 60439

January 1994

Work sponsored by United States Department of Energy, Assistant Secretary for Policy, Planning, and Program Evaluation, Office of Environmental Analysis 
This report is printed on recycled paper. 


\section{CONTENTS}

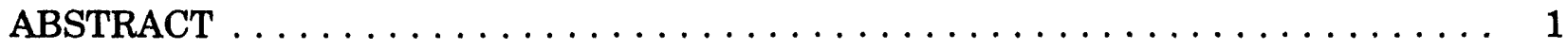

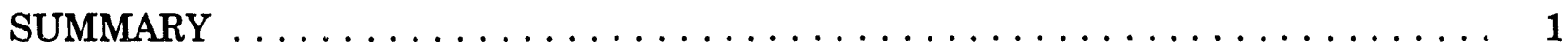

1 IDENTIFICATION AND IMPACT OF NON-SO ${ }_{2}$ REGULATIONS

ON UTILITY COMPLIANCE WITH TITLE IV $\ldots \ldots \ldots \ldots \ldots \ldots$

1.1 Title IV $\mathrm{SO}_{2}$ Regulations and Utility Compliance Strategies . . . . . . . . . 5

1.2 Non- $\mathrm{SO}_{2}$ Regulations Affecting Utility Compliance Strategies $\ldots \ldots \ldots \ldots$

1.2 .1 Title IV Controls on $\mathrm{NO}_{\mathrm{x}} \ldots \ldots \ldots \ldots \ldots \ldots \ldots \ldots \ldots \ldots$

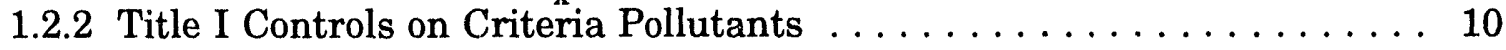

1.2.3 Title III Hazardous Air Pollutant Controls . . . . . . . . . . . . . . . . 20

1.2.4 New Source Performance Standards for $\mathrm{SO}_{2}$ and $\mathrm{NO}_{\mathrm{x}}$ Emissions . . . . . . 22

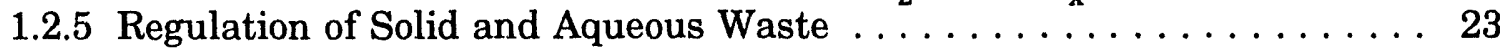

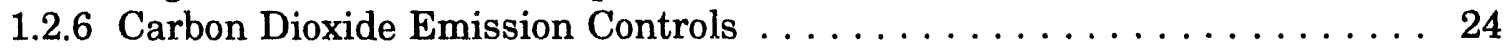

1.2 .7 Summary . . . . . . . . . . . . . . . . . . . . . . . .

2 PUBLIC UTILITY REGULATION UNDER TITLE IV . . . . . . . . . . 31

2.1 Utility Rate Regulation and Distortional Pressures . . . . . . . . . . 31

2.2 Regulatory Treatment of $\mathrm{SO}_{2}$ Compliance Options . . . . . . . . . . . . 34

2.3 Utility Compliance Behavior and Portfolio Choice . . . . . . . . . . . . . 40

3 ISSUES OF SYNERGISTIC POLLUTION CONTROL AND COPOLLUTANTS ASSOCIATED WITH UTILITY $\mathrm{SO}_{2}$ COMPLIANCE OPTIONS $\ldots \ldots \ldots \ldots$

3.1 Framework and Description of Base Utility Unit for Examining

Synergies and Copollutants . . . . . . . . . . . . . . . . 45

3.2 Utility $\mathrm{SO}_{2}$ Compliance Methods and Associated Pollutants and Costs . . . . 46

3.2.1 Current Utility Phase I and Phase II Compliance Decisions . . . . . . . . 46

3.2.2 Selection and Justification of Technologies Chosen for Examination . . . 47

3.2.3 Examination of Selected Compliance Options Based on Cost,

Pollutants, Flexibility, and Ability to Implement . . . . . . . . . 48

4 ENVIRONMENTAL POLICY INTERACTIONS AND UTILITY $\mathrm{SO}_{2}$

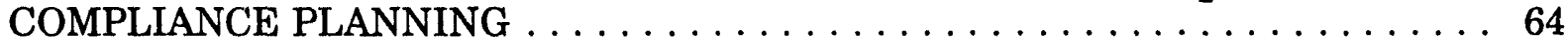

4.1 Compliance Planning under Multiple Regulations $\ldots \ldots \ldots \ldots \ldots \ldots$. . . . 64

4.2 Impact of Regulatory Controls on $\mathrm{SO}_{2}$ Compliance $\ldots \ldots \ldots \ldots \ldots \ldots$

4.2.1 Interaction of Title IV with Title $\mathrm{I}^{-\mathrm{NO}_{\mathrm{x}}} \ldots \ldots \ldots \ldots \ldots \ldots \ldots \ldots$

4.2 .2 Interaction of Title $\mathrm{IV}_{-\mathrm{SO}_{2}}$ with Title III $\ldots \ldots \ldots \ldots \ldots \ldots \ldots$

4.2.3 Interaction of Title IV-SO $\mathrm{SO}_{2}$ with the Regulation of High-Volume

Combustion Waste ...................... 80

4.2.4 Interaction of Title IV-SO $\mathrm{SO}_{2}$ with Greenhouse Gas Regulations . . . . . 81

4.3 New Unit Synergies $\ldots \ldots \ldots \ldots \ldots \ldots \ldots \ldots \ldots \ldots \ldots \ldots$

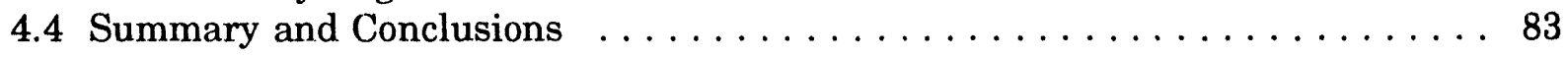




\section{CONTENTS (Cont.)}

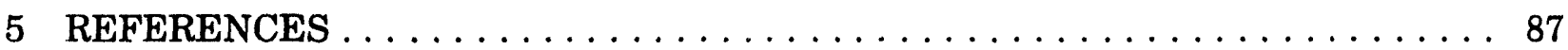

APPENDIX: Significant Federal Register Notices Affecting Utility Emissions . . . . . 91

\section{TABLES}

1.1 National Ambient Air Quality Standards $\ldots \ldots \ldots \ldots \ldots \ldots \ldots \ldots$

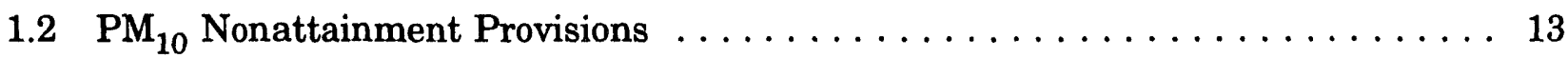

1.3 Ozone Nonattainment Provisions $\ldots \ldots \ldots \ldots \ldots \ldots \ldots \ldots \ldots \ldots \ldots \ldots \ldots \ldots$

1.4 EPA-Proposed RACT Standards for Utility Boilers $\ldots \ldots \ldots \ldots \ldots \ldots \ldots$

1.5 STAPPA/ALAPCO-Recommended $\mathrm{NO}_{\mathrm{x}}$ RACT for Utility Boilers $\ldots \ldots \ldots \ldots 16$

1.6 Maximum Pollutant Increments for Class I and Class II Areas .......... 18

1.7 Selected Provisions of Global Climate Change Bills in the 102nd Congress . . . . 28

3.1 Configuration of Typical or Reference Plant $\ldots \ldots \ldots \ldots \ldots \ldots \ldots \ldots$

3.2 Summary of Compliance Options for Phase I Affected Units $\ldots \ldots \ldots \ldots \ldots 4$

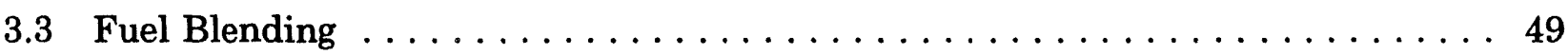

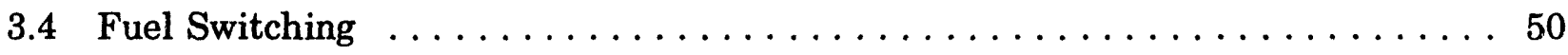

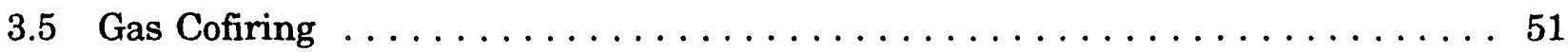

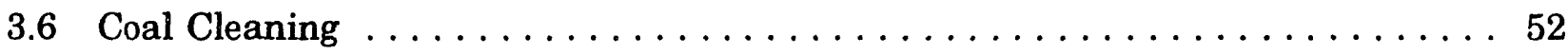

3.7 Wet Lime/Limestone Flue Gas Desulfurization $\ldots \ldots \ldots \ldots \ldots \ldots \ldots \ldots$

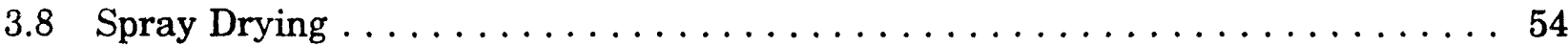

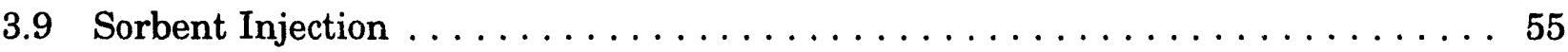

3.10 Wet Regenerable Flue Gas Desulfurization $\ldots \ldots \ldots \ldots \ldots \ldots \ldots \ldots$

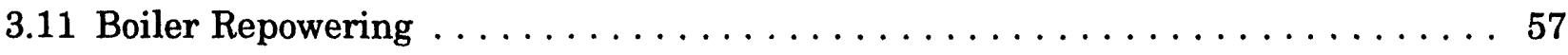

3.12 Comparison of $\mathrm{SO}_{2}$ Removal Methodologies $\ldots \ldots \ldots \ldots \ldots \ldots \ldots \ldots \ldots \ldots \ldots$ 


\section{TABLES (Cont.)}

4.1 Percent Annual Emission Reduction from CCT Unit

Compared to a PC/FGD Unit . . . . . . . . . . . . . . . . . . 83

A.1 Significant Federal Register Notices Affecting Utility Emissions - Title IV

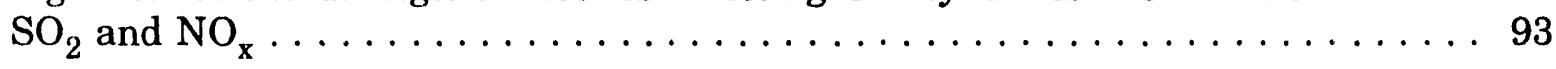

A.2 Significant Federal Register Notices Affecting Utility Emissions - Title I

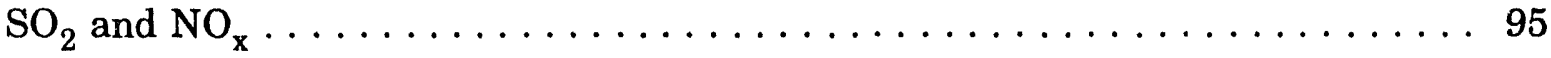

A.3 Significant Federal Register Notices Affecting Utility Air

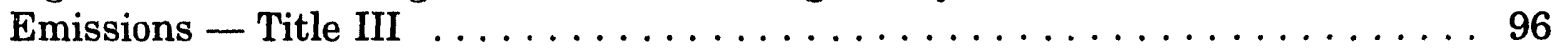

\section{FIGURES}

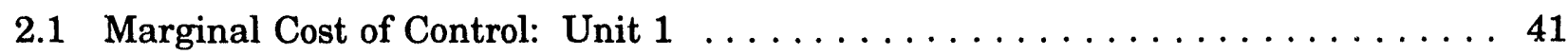

2.2 Marginal Cost of Control: Unit $2 \ldots \ldots \ldots \ldots \ldots \ldots \ldots \ldots \ldots \ldots \ldots \ldots \ldots \ldots$

2.3 Marginal Cost of Control: Unit $3 \ldots \ldots \ldots \ldots \ldots \ldots \ldots \ldots \ldots \ldots \ldots$

2.4 Utility Compliance Option Supply Curve $\ldots \ldots \ldots \ldots \ldots \ldots \ldots \ldots$

4.1 Utility Compliance Planning Process $\ldots \ldots \ldots \ldots \ldots \ldots \ldots \ldots \ldots \ldots \ldots \ldots \ldots \ldots \ldots$

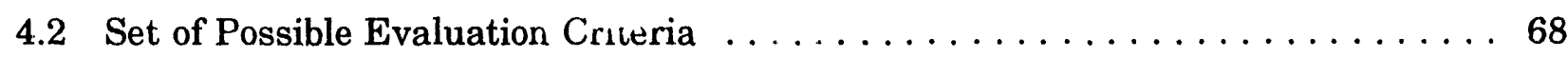

4.3 Compliance Planning under Concurrent or Existing Regulations ..........69 69

4.4 Synergies and Compliance Planning $\ldots \ldots \ldots \ldots \ldots \ldots \ldots \ldots \ldots \ldots \ldots$

4.5 Phase I Compliance Selection and Ramifications ................ 72

4.6 Title IV Phase I Compliance and Possible Title III Regulatory Outcomes . . . . 78 


\title{
SYNERGIES AND CONFLICTS IN MULTIMEDIA POLLUTION CONTROL RELATED TO UTILITY COMPLIANCE WITH TITLE IV OF THE CLEAN AIR ACT AMENDMENTS OF 1990
}

\author{
by
}

K.A. Bailey, A.P. Loeb, J.W. Formento, and D.W. South

\begin{abstract}
Most analyses of utility strategies for meeting Title IV requirements in the Clean Air Act Amendments of 1990 have focused on factors relating directly to utilities' sulfur dioxide control costs; however, there are a number of additional environmental requirements that utilities must meet at the same time they comply with the acid rain program. To illuminate the potential synergies and conflicts that these other regulatory mandates may have in connection with the acid rain program, it is necessary to conduct a thorough, simultaneous examination of the various programs. This report (1) reviews the environmental mandates that utilities must plan to meet in the next decade concurrently with those of the acid rain program, (2) evaluates the technologies that utilities may select to meet these requirements, (3) reviews the impacts of public utility regulation on the acid rain program, and (4) analyzes the interactions among the various programs for potential synergies and conflicts. Generally, this report finds that the lack of coordination among current and future regulatory programs may result in higher compliance costs than necessary. Failure to take advantage of cost-effective synergies and incremental compliance planning will increase control costs and reduce environmental benefits.
\end{abstract}

\section{SUMMARY}

The Clean Air Act Amendments of 1990 introduced a broad range of air quality programs that will affect the environmental control programs of electric utility and nonutility generators. Perhaps the most innovative of the new Act's programs is Title IV. Title IV creates a program of tradeable emission allowances for sulfur dioxide $\left(\mathrm{SO}_{2}\right)$ in order to reduce utility $\mathrm{SO}_{2}$ emissions to half of their 1980 levels. Title IV also specifies emission standards for utility emissions of nitrogen oxides $\left(\mathrm{NO}_{\mathrm{x}}\right)$ by boiler type. Title IV is being implemented in two phases. Phase I begins in 1995 and affects the 263 utility units emitting the highest levels of $\mathrm{SO}_{2}$. Phase II begins in 2000 and affects almost every utility fossil-fuel-fired unit. Utilities affected by Title IV have begun implementing $\mathrm{SO}_{2}$ compliance plans for Phase I.

Utilities planning for $\mathrm{SO}_{2}$ compliance are considering the relative fuel, technology, and allowance costs in their planning calculations. In addition, utilities must consider many 
other existing and potential environmental regulations and requirements. These regulations include the following:

- Title IV controls of $\mathrm{NO}_{\mathrm{x}}$,

- Title I controls of $\mathrm{NO}_{\mathbf{x}}$,

- Potential Title III controls of hazardous air pollutants,

- Potential carbon dioxide measurement and control requirements,

- New source requirements,

- Revisions and requirements for prevention of significant deterioration and for best available control technology, and

- Regulation of solid and aqueous wastes.

Ideally, utilities will choose compliance strategies that minimize total environmental compliance costs while maintaining system reliability. Certain control options and strategies can reduce two or more pollutants at a lower cost than separate controls for each of those pollutants. A utility seeking to minimize compliance costs will choose compliance options that exhibit cost-effective emission control synergies.

However, a variety of factors may force utilities to choose more expensive options that control a single pollutant to a prescribed level. This incremental strategy may be an inefficient choice if more stringent control levels are later required or if a synergistic option would have cost-effectively controlled multiple pollutants. Factors such as regulatory uncertainty, timing of control requirements, and the regulatory structure of the industry may lead to such control choice inefficiencies.

To capitalize on potential cost savings through synergistic controls, several conditions must be met. First, regulatory flexibility is needed. Under the current rate regulatory structure, expenditures on controls for potentially regulated pollutants may not be considered prudent if these controls are not "used-and-useful." Relaxing the standard of "used-anduseful" may allow for control synergies to be gained. Second, integrated timing of regulatory programs would allow easier and more cost-effective planning for the affected parties. Finally, for those pollutants that currently are unregulated but have a potential of near-term regulation (e.g., hazardous air pollutants), early-emission-reduction bonus programs and the like could encourage exploitation of cost-effective control synergies. 


\section{IDENTIFICATION AND IMPACT OF NON-SO 2 REGULATIONS ON UTILITY COMPLIANCE WITH TITLE IV}

It is widely recognized that enactment of the Clean Air Act Amendments of $1990^{1}$ (CAAA) will profoundly affect electric power generation. The centerpiece of the CAAA is Title IV, which establishes a program to reduce acid deposition by controlling utility emissions of acid precursors, primarily sulfur dioxide $\left(\mathrm{SO}_{2}\right)$ and, to a lesser extent, oxides of nitrogen $\left(\mathrm{NO}_{\mathbf{x}}\right)$. In conjunction with the permits program under Title $\mathrm{V}$ of the CAAA, utilities must submit compliance plans detailing their compliance strategies for each Title IV affected unit. $^{2}$

By virtue of its innovative allowance trading mechanism for $\mathrm{SO}_{2}$, as well as other potential market-based mechanisms for $\mathrm{NO}_{\mathrm{x}}$, Title IV gives utilities unprecedented flexibility to choose their strategies for controlling $\mathrm{SO}_{2}$ emissions; however, this flexibility gives rise to other concerns.

Each fuel or process change adopted by a utility for $\mathrm{SO}_{2}$ compliance will also affect other combustion emissions and by-products. In addition to $\mathrm{SO}_{2}$ and $\mathrm{NO}_{\mathrm{x}}$, the uncontrolled combustion of fossil fuels produces fly ash emitted as particulates, hazardous air pollutants (HAPs) such as mercury $(\mathrm{Hg})$ and other trace metals, radionuclides, and carbon dioxide $\left(\mathrm{CO}_{2}\right)$.

Many of these pollutants are subject to their own regulatory requirements. Under the Clean Air Act of $1970^{3}$ (CAA), fossil-fuel utility units were regulated for their $\mathrm{SO}_{2}$, particulate, and $\mathrm{NO}_{\mathrm{x}}$ emissions, in some cases by several CAA programs concurrently. ${ }^{4}$ To date, reduction of $\mathrm{SO}_{2}$ emissions has been achieved through scrubbing, fuel switching, and fuel blending. Control of particulates has been achieved through the use of electrostatic precipitators, scrubbers, and baghouse technologies. While $\mathrm{NO}_{\mathrm{x}}$ has been controlled on new

1 Pub.L. 101-549, 104 Stat. 2399 (1990), signed into law by President Bush on November 15, 1990.

2 A "unit" is defined by Section 402(15) as a fossil-fuel-fired combustion device, and a "utility unit" is defined generally by Section $402(17)$ as a unit that produces electricity for sale, including all those operated by investor-owned or municipal utilities, as well as any nonutility boiler that generates electricity for sale. A unit that cogenerates steam and electricity is excluded unless the unit supplies more than one-third of its power to any utility power distribution system. An "affected unit" is defined by Section $402(2)$ as one that is subject to the requirements of Title IV. Units that are affected under Phase I are listed in Section 404, Table A. Units that are affected under Phase II are existing utility units that meet criteria under Section 405(b). Permits and compliance plans are required under Section 408.

3 Pub.L. 91-604, 84 Stat. 1676 (1970), as amended Pub.L. 95-95, 91 Stat. 685 (1977), codified at 42 U.S.C. $\$ 7401$ et seq.

4 For example, $\mathrm{NO}_{\mathrm{x}}$ is regulated in Title I, Title II, and Title IV. This results from the fact that titles of the CAA are not constructed as mutually exclusive, and $\mathrm{NO}_{\mathrm{x}}$ qualifies for regulation under several of them. It should also be pointed out that only $\mathrm{NO}_{2}$ is regulated as a criteria pollutant, whereas $\mathrm{NO}_{\mathrm{x}}$ is regulated in the control of acid deposition and ozone. 
generating units through various boiler-firing schemes, existing units have been able to avoid most $\mathrm{NO}_{\mathrm{x}}$ control requirements. By contrast, fossil-fuel utility units have not been regulated under the CAA for their $\mathrm{HAP}$, radionuclide, or $\mathrm{CO}_{2}$ emissions.

In addition to air pollutant emissions, the uncontrolled combustion of fossil fuels produces discharges of heat, wastewater, and potentially large amounts of slag and bottom ash as solid waste. Thermal and wastewater discharges are regulated by the Clean Water Act (CWA). ${ }^{5}$ Thermal discharges are controlled through cooling towers, cooling pools, and recycling. Wastewater discharges are controlled through the use of water recycling and point source controls. Combustion wastes are regulated as solid wastes by the Resource Conservation and Recovery Act $^{6}$ (RCRA), which requires waste generators to dispose of such wastes in sludge pools or landfills. Combustion wastes are not classified as hazardous under RCRA Section $3001(b)(3)(C){ }^{7}$

Most analyses of utility strategies for compliance with Title IV requirements have focused on factors related directly to utility $\mathrm{SO}_{2}$ control costs, such as technology availability, fuel prices, technology costs, and $\mathrm{SO}_{2}$ allowance prices. While these factors will play a primary role in utility compliance strategies, compliance with regulations controlling other air emissions and waste discharges will also be necessary. A complete analysis of utility compliance strategies must therefore contemplate the entire range of environmental regulatory mandates affecting utilities. The regulations that currently affect - or in the future may affect - utility $\mathrm{SO}_{2}$ compliance strategies are the following:

- Controls on $\mathrm{NO}_{\mathrm{x}}$ in Phase I and Phase II of the acid rain program under Title IV;

- Controls on $\mathrm{SO}_{2}, \mathrm{NO}_{\mathrm{x}}$, and $\mathrm{PM}_{10}$ (particulate matter of diameter less than $10 \mu \mathrm{m}$ ) in nonattainment areas under Title I;

- Visibility controls affecting Class I areas under Title I;

- Possible controls on $\mathrm{Hg}$ and other hazardous air pollutants under Title III;

- Possible controls on $\mathrm{CO}_{2}$ emissions (future legislation); and

- Regulation of solid and aqueous waste produced by control technologies for air pollutants under the RCRA and the CWA.

533 U.S.C. \& 1251 (1972).

642 U.S.C. $\$ 6901$ et seq.

7 After consideration, the U.S. Environmental Protection Agency (EPA) has declared that coal combustion by-products, including fly ash, boiler ash, boiler slag, and scrubber waste, should not be regulated as hazardous wastes. The regulatory determination was published at 58 Fed.Reg. 42466 (Aug. 9, 1993). See Utility Environment Reporter, August 6, 1993. 
Utilities that focus only on current deadlines and do not take the full list of compliance mandates into consideration may fail to adopt strategies that control additional pollutants and therefore take the countervailing risk of having higher total compliance costs in the long run.

\subsection{TITLE IV SO, REGULATIONS AND UTILITY COMPLIANCE STRATEGIES}

The Title IV $\mathrm{SO}_{2}$ program is designed to reduce utility $\mathrm{SO}_{2}$ emissions to half of 1980 levels. A utility unit becomes subject to regulation in phases:

- Phase I. Beginning in 1995, 110 plants larger than 100 megawatts (MW) with $\mathrm{SO}_{2}$ emission rates greater than 2.5 pounds per million British thermal units ${ }^{8}$ (lb/mmBtu) will become "affected units." According to the Environmental Protection Agency (EPA), there are 263 Phase I units, which Congress listed by name in the statute. ${ }^{9}$ Phase I units represent a total capacity of approximately 82,000 MW.

- Phase II. Beginning in 2000, all utility units will be affected. According to the EPA, there are more than 2,300 Phase II units (including both Phase I and Phase II units). ${ }^{10}$ Phase II units represent a total capacity of $377,600 \mathrm{MW}$.

The Title IV $\mathrm{SO}_{2}$ program establishes the first federal standards applicable to all utility sources. In the past, controls have been applied only to new sources and sources in nonattainment areas. ${ }^{11}$

The great regulatory innovation of the acid rain program is the use of an emission trading market. Instead of establishing emission standards for affected units, as other programs have done in the past, the Title $\mathrm{IV} \mathrm{SO}_{2}$ program controls emissions by allocating to each affected party a quantity of allowances. Each allowance represents a limited right

8 Classifications and standards expressed in Btu measure the amount of energy consumed by a utility unit; classifications and standards expressed in MW measure the amount of power produced.

9 Section 404, Table A.

1057 Fed.Reg. 29940 (July 7, 1992), 57 Fed.Reg. 30034 (July 7, 1992). Argonne estimates that the total number is 2,456 units.

11 Title IV control requirements apply to all fossil-fuel combustion units with a nameplate capacity greater than $25 \mathrm{MW}$ (Section 402(8)); however, any third party, including brokers, may hold allowances for any purpose. In addition, under Section $410(\mathrm{a})$, industrial sources of $\mathrm{SO}_{2}$ can "opt into" the program and earn credits to sell by making reductions in their $\mathrm{SO}_{2}$ emissions. The EPA proposed rules for nonaffected units to opt in at 58 Fed.Reg. 50088 (Sept. 24, 1993). 
to emit 1 ton of $\mathrm{SO}_{2}$ during a specified year. The CAAA do not consider allowances a full property right, but they come very close. ${ }^{12}$

Allowances serve as the mechanism for compliance. Each affected unit is allocated its allowances based on its baseline fuel consumption. The baseline is calculated from the average yearly fuel consumption for the period 1985-87. In Phase I, allowances are allocated at the rate of 2.5 tons of $\mathrm{SO}_{2}$ times the number of mmBtu consumed in the baseline. In Phase II, allowances are allocated at the rate of 1.2 tons of $\mathrm{SO}_{2}$ times the number of mmBtu consumed in the baseline. Generally, Phase II requires utility units to meet an emission allowance level of $\leq 1.2 \mathrm{lb} / \mathrm{mmBtu}$, with an overall nationwide cap of 8.9 million total allowances. The 8.9-million-ton absolute cap on $\mathrm{SO}_{2}$ emissions preserves the reductions against future increases associated with the projected growth in power demand.

Allowances also serve as a common currency for trading. Allowances may be used in three ways: (1) allowances may be used to cover actual $\mathrm{SO}_{2}$ emissions and, once used, are spent; (2) allowances may be banked and used in a later year; or (3) allowances may be sold to another party or bought and used to cover current emissions, banked for later use, or resold.

In essence, a utility's decision process for each unit may be distilled into a single equation: actual $\mathrm{SO}_{2}$ emissions must be less than or equal to allowances held. ${ }^{13} \mathrm{~A}$ utility that achieves this result at the end of each year through the proper procedures has met its requirements under Title $I V$. Thus, the objective of every party who owns an affected unit (other than those who may make the economically unfavorable choice to violate) will be to reduce the left side of the equation (despite the costs of doing so) or increase the right side of the equation (despite the costs of doing so). It is this process that gives utilities the flexibility of choice under Title IV. Trading options are likely to become more prominent in Phase II, when the pool will be larger and compliance costs will likely be higher.

However, the ability to freely trade allowances is constrained by other standards under the Act. Title IV does not exempt utilities from other requirements of the Act, including (1) health-based ambient air quality standards, (2) prevention of significant deterioration (PSD) requirements, (3) new source performance standards (NSPSs), and (4) state-issued air regulations. ${ }^{14}$

12 Sections 402(3) and 403(f).

13 To stimulate the market and to provide a public source of allowances, particularly for new units to which no allowances are allocated, some of the allowances are held in reserve to be auctioned off (Section 416). The EPA delegated its authority to administer such auctions and sales to the Chicago Board of Trade (57 Fed.Reg. 46167 [Oct. 7, 1992]). The proceeds returned from auctions are taxable. To encourage trading, the EPA has reminded utilities that it would be to their advantage to buy back their own allowances from the reserve.

14

Section 413. 
Title IV permit plans for Phase I units were due on February 15, 1993, for review by regional EPA offices (Bailey et al. 1993). In them, each owner or operator of a Phase I unit must show how he will meet the requirements of Phase I. A utility with a Phase I unit has four compliance options to use singly or in combination:

- The utility may hold and use allowances and bank those that are not used;

- The utility may apply for a Phase I extension, which gives it two years' delay (until January 1, 1997) in exchange for the adoption of technologies that reduce emissions $90 \%$ or more; ${ }^{15}$

- The utility may apply to reassign all or part of a Phase I unit's allocation to a substitute unit, which makes both units "affected" for purposes of Title I; a utility might choose to do this in Jrder to bring in the Phase II unit so it could free up its allowances; by virtue of the substitution, the unit also becomes affected in Phase I for Title IV NO requirements; ${ }^{16}$ and/or

- The utility may reduce utilization at a Phase I unit and shift it to a nonaffected "compensating unit"; but if the utility reduces utilization and cannot explain where the capacity went, it must surrender allowances. ${ }^{17}$

In addition, Phase I units may earn bonus allowances from the Conservation and Renewable Energy Reserve. ${ }^{18}$ Compliance plans for Phase II units are due on January $1,1996 .^{19}$

Several challenges remain outstanding for electric utilities. For those that have Phase I units, as well as Phase II units, the task of integrating the phases is considerable. One of the greatest uncertainties in optimizing the strategy is the price of allowances. In addition, fuel price uncertainty and demand fluctuations are a challenge to planning.

15 Section $404(d)$.

16 Sections 404(b) and (c).

17 Legitimate utilization reductions, which will be accepted by the EPA, are shifting to a designated compensating unit, identifying a sulfur-free generator (such as a wind, solar, or nuclear power source), use of an energy conservation mechanism (e.g., the EPA's "Green Lights" program), or improving unit efficiency.

18 Note that the Federal Register notice for this program contains a typo; the date for installation is not 1993 , as it states, but 1992 . The reserve contains 300,000 allowances, to be used for conservation or for biomass, solar, geothermal, or wind generation. Under Section 404(f)(2)(B)(iv), an electric utility is to be guaranteed net income neutrality for qualified energy conservation measures so that there is no penalty to the utility for its conservation investments.

Sections 408(c) and (d). 


\section{$1.2 \mathrm{NON}^{-\mathrm{SO}_{2}}$ REGULATIONS AFFECTING UTILITY COMPLIANCE STRATEGIES}

Difficulties in planning compliance with the acid rain provisions will be compounded by the additional programs under the CAA. Each of the programs that follows may either affect utilities' choice of strategies in the near term or introduce uncertainties into the decision-making process or both.

\subsubsection{Title IV Controls on $\mathrm{NO}_{\mathbf{x}}$}

In conjunction with the Title IV $\mathrm{SO}_{2}$ control program, Congress established the

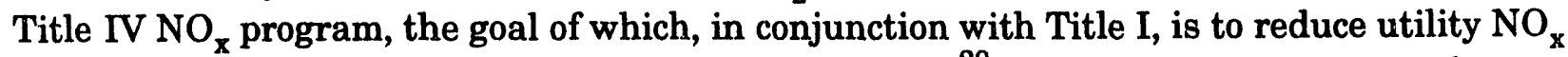
emissions ultimately by approximately 2 million tons/yr. ${ }^{20}$ The $\mathrm{NO}_{\mathrm{x}}$ control program focuses on coal-fired boilers, which are the source of $80 \%$ of utility $\mathrm{NO}_{\mathrm{x}}$ emissions.

The $\mathrm{NO}_{\mathrm{x}}$ program is implemented in the same two phases as the $\mathrm{SO}_{2}$ program. The $\mathrm{NO}_{\mathrm{x}}$ emission limitations become applicable to units at the time such units become affected units under the $\mathrm{SO}_{2}$ program. ${ }^{21}$

The Title IV NO $\mathrm{N}_{\mathrm{x}}$ program, unlike the $\mathrm{SO}_{2}$ program, does not establish a market as the primary means of setting emission limitations. Except to the extent that averaging provisions of Section 407(e) are used, the maximum allowable $\mathrm{NO}_{\mathrm{x}}$ emission rates are established by technology-based rules. For Phase I units, the emission standards are set out in the statute. Section $407(b)(1)$ establishes rates for tangentially fired boilers and dry bottom wall-fired boilers (other than units applying cell burner technology) of $0.45 \mathrm{lb} / \mathrm{mmBtu}$ and $0.50 \mathrm{lb} / \mathrm{mmBtu}$, respectively.

Only Phase I affected units that have these boiler types are subject to $\mathrm{NO}_{\mathrm{x}}$ controls. Phase I units that have other boiler types are not subject to $\mathrm{NO}_{\mathrm{x}}$ regulation until Phase II, when emission standards for those types of boilers are required to be set. The EPA was required to promulgate regulations by May 1992 establishing the allowable emission limitations, but they were only proposed in November $1992 .^{22}$ The standards must be based on the statutory rates, but the EPA is given the discretion to make the standards less

20 The 2-million-ton reduction per year is to be met in Phase II of the acidic deposition control program (NAPAP 1993).

21 Section 407(a). See Sections 404 and 405 for Phase I and Phase II affected units; however, note that $\mathrm{NO}_{\mathrm{x}}$ compliance, like Phase $\mathrm{I} \mathrm{SO}_{2}$ compliance, can be delayed and altered depending on the various delay and substitution programs allowed under Sections 404(b), 404(d), and 409(b). Also note that similar to the $\mathrm{SO}_{2}$ control program, petitions of extension may be granted if technical or market forces prevent compliance.

22 The EPA established an advisory committee at 56 Fed.Reg. 21348 (May 8, 1991) and issued a proposed rule at 57 Fed.Reg. 55632 (Nov. 25, 1992) and 57 Fed.Reg. 61489 (Dec. 24, 1992) (corrections to the proposed rule). 
stringent than the statutory rates if it finds they cannot be achieved using low- $\mathrm{NO}_{\mathrm{x}}$ burner technology. At present, the EPA believes that these emission standards can be met, although comments received in response to its proposed $\mathrm{NO}_{\mathrm{x}}$ rule will shed further light on the question.

In Phase II, affected Phase II units are required to meet the previously issued $\mathrm{NO}_{\mathrm{x}}$ standards for tangentially fired boilers and dry bottom wall-fired boilers. In addition, the EPA is required to issue rules establishing $\mathrm{NO}_{\mathrm{x}}$ emission limitations for remaining boiler types, including wet bottom wall-fired boilers, cyclone boilers, units applying cell burner technology, and all others. The rules for the remaining boiler types apply to both Phase I and Phase II units. Thus, some Phase I affected units only become subject to $\mathrm{NO}_{\mathrm{x}}$ standards in Phase II. The rules must be issued by January 1, 1997, and they must be based on "retrofit application of the best system of continuous emission reduction." The EPA may also revise the Phase I requirements if more effective technology has become available. ${ }^{23}$

$A$ unit that is unable to meet its emission limitation by installing low- $\mathrm{NO}_{x}$ burner technology or that, after installing low- $\mathrm{NO}_{x}$ burner technology, does not achieve the required emission reduction may be granted a less stringent standard. ${ }^{24}$ In this case, an alternative emission limit must be specified. For those units requiring an extension of the compliance deadline, an extension of up to $\mathbf{1 5}$ months could be granted in the case of Phase I affected units. Section 407(d) specifically allows alternative compliance methods (apart from the use of low- $\mathrm{NO}_{\mathrm{x}}$ burner technology), including reburning (with coal, oil, or natural gas), selective noncatalytic reduction, and selective catalytic reduction. As is typical with other pollution control regulations, requirements of best operating practices and procedures are required for units using alternative controls or alternative emission limits.

Section 407(e) allows $\mathrm{NO}_{\mathrm{x}}$ emission averaging at an affected plant. In lieu of the foregoing standards, two or more units may petition the permitting authority for alternative limitations, so long as such units ensure that the emissions are less than or equal to the $\mathrm{NO}_{\mathrm{x}}$ emissions that would have resulted had the units each been operated in compliance with their individual emission limitations. Analogous to the emission bubble program, the $\mathrm{NO}_{\mathrm{x}}$ emission rate for the facility may not exceed the Btu-weighted emission rate for the sum of all units at the plant (McDermott and South 1990). ${ }^{25}$ This allows the owner(s) to choose the most cost-effective control strategy for the plant and avoid potentially expensive retrofit costs.

Current issues in the $\mathrm{NO}_{\mathrm{x}}$ rule-making proceeding involve the definition of low- $\mathrm{NO}_{\mathrm{x}}$ burner technology and the potential inability of dry bottom wall-fired units to meet their

23 Section $407(b)(2)$.

24 Section 407(d) and EPA-proposed rules at 57 Fed.Reg. 55632 (Nov. 25, 1992) and 57 Fed. Reg. 61489 (Dec. 24, 1992).

2544 Fed.Reg. 71780 (Dec. 11, 1979). 
statutory $\mathrm{NO}_{\mathrm{x}}$ standard. ${ }^{26}$ Both issues focus largely on technology implementation. The EPA has proposed two options. Under option 1, the unit may apply for an alterative emission limit if the installation is "technically infeasible . . or would produce an additional $\mathrm{NO}_{\mathrm{x}}$ emission reduction of less than $0.05 \mathrm{lb} / \mathrm{mmBtu}$ relative to the $\mathrm{NO}_{\mathrm{x}}$ emission reduction that would have been achieved by low $\mathrm{NO}_{\mathrm{x}}$ burners that do not incorporate overfire air" (STAPPA/ALAPCO 1992). ${ }^{27}$ Option 2 does not recognize overfire air as a low- $\mathrm{NO}_{\mathrm{x}}$ burner technology; the owner is not required to implement overfire air in order to apply for an alternative emission limit. Option 2 allows affected units greater flexibility and possibly lower costs, as the unit's standards may not be as strict.

\subsubsection{Title I Controls on Criteria Pollutants}

Sections 108 and 109 of the 1970 CAA require the EPA to promulgate national ambient air quality standards (NAAQSs) for the criteria pollutants. The list of criteria pollutants consists of particulates $\left(\mathrm{PM}_{10}\right), \mathrm{SO}_{2}$, carbon monoxide (CO), nitrogen dioxide $\left(\mathrm{NO}_{2}\right)$, ozone $\left(\mathrm{O}_{3}\right)$, and lead $(\mathrm{Pb}) .{ }^{28}$ The NAAQSs are listed in Table 1.1.

Section 110 of the Act sets out the procedures for attainment of the NAAQSs. States are required to submit state implementation plans (SIPs) showing how they plan to achieve the standards. For purposes of Title I, all areas of the country are designated as either "nonattainment," "attainment," or "unclassifiable," according to whether local conditions meet the standards. 29

Electric utilities are subject to controls under the NAAQSs because of their $\mathrm{PM}_{10}$, $\mathrm{SO}_{2}$, and $\mathrm{NO}_{2}$ emissions. ${ }^{30}$ Utilities may also be subject to controls as part of strategies to reduce $\mathrm{O}_{3}$ that are based on prevention of its formation by control of its precursors, that is, volatile organic compounds (VOCs) and $\mathrm{NO}_{\mathrm{x}}$. Control of $\mathrm{O}_{3}$ is considered the highest priority among the criteria pollutants, as 62.9 million persons live in counties with $\mathrm{O}_{3}$ levels that exceed the standard (EPA 1991).

26 See EPA-proposed rule, supra.

2757 Fed.Reg. at 55636 (Nov. 25, 1992). An overfire air system is one that installs air ports in the furnace above the top row of burners to allow for a second combustion of the fuel to reduce $\mathrm{NO}_{\mathbf{x}}$.

28 In 1971, the EPA issued standards for six criteria pollutants - $\mathrm{SO}_{2}$, total suspended particulates (TSPs), CO, hydrocarbons (HCs), photochemical oxidants (i.e., ozone), and $\mathrm{NO}_{2}$. Since publication of the original six NAAQSs, the EPA has dropped HCs, added lead, narrowed the particulate standard from TSP to $\mathrm{PM}_{10}$ (which controls only particles with aerodynamic diameters smaller than $10 \mu \mathrm{m}$ ), and made various additional changes to the standards themselves.

29 Section 101(a) of the CAAA and Section 107(d)(1) of the CAA.

30 According to the EPA, 18.8 million persons live in counties with $\mathrm{PM}_{10}$ levels in excess of the standard; for $\mathrm{SO}_{2}$ and $\mathrm{NO}_{2}$, the corresponding numbers are 1.4 million and 8.5 million (EPA 1991). 
TABLE 1.1 National Ambient Air Quality Standards (as in Effect in 1990)

\begin{tabular}{|c|c|c|c|c|}
\hline \multirow[b]{2}{*}{ Pollutant } & \multicolumn{2}{|c|}{ Primary Standards } & \multicolumn{2}{|c|}{ Secondary Standards } \\
\hline & Averaging Time & $\begin{array}{l}\text { Standard Level } \\
\text { Concentration }^{\mathrm{a}}\end{array}$ & Averaging Time & $\begin{array}{l}\text { Standard Level } \\
\text { Concentration }\end{array}$ \\
\hline $\mathrm{PM}_{10}$ & $\begin{array}{c}\text { Annual arithmetic } \\
\text { mean }^{\mathrm{b}} \\
\text { 24-hour }\end{array}$ & $\begin{array}{c}50 \mu \mathrm{\mu g} / \mathrm{m}^{3} \\
150 \mu \mathrm{g} / \mathrm{m}^{3} \\
(0.03 \mathrm{ppm})\end{array}$ & $\begin{array}{l}\text { Same as primary } \\
\text { Same as primary }\end{array}$ & \\
\hline $\mathrm{SO}_{2}$ & $\begin{array}{c}\text { Annual arithmetic } \\
\text { mean }^{\mathrm{c}} \\
24-\text { hour }^{\mathrm{d}}\end{array}$ & $\begin{array}{c}80 \mu \mathrm{g} / \mathrm{m}^{3} \\
(0.14 \mathrm{ppm}) \\
365 \mu \mathrm{g} / \mathrm{m}^{3}\end{array}$ & 3-hour ${ }^{\mathrm{c}}$ & $\begin{array}{l}1,300 \mu \mathrm{\mu g} / \mathrm{m}^{3} \\
(0.50 \mathrm{ppm})\end{array}$ \\
\hline $\mathrm{CO}$ & & $\begin{array}{c}9 \mathrm{ppm} \\
\left(10 \mathrm{mg} / \mathrm{m}^{3}\right)\end{array}$ & None & \\
\hline & 1-hour ${ }^{d}$ & $\begin{array}{c}35 \mathrm{ppm} \\
\left(40 \mathrm{mg} / \mathrm{m}^{3}\right)\end{array}$ & None & \\
\hline $\mathrm{NO}_{2}$ & $\begin{array}{c}\text { Annual arithmetic } \\
\text { mean }\end{array}$ & $\begin{array}{c}0.053 \mathrm{ppm} \\
\left(100 \mu \mathrm{g} / \mathrm{m}^{3}\right)\end{array}$ & Same as primary & \\
\hline $\mathrm{O}_{3}$ & $\begin{array}{l}\text { Maximum daily } \\
\text { 1-hour average }\end{array}$ & $\begin{array}{c}0.12 \mathrm{ppm} \\
\left(235 \mu \mathrm{g} / \mathrm{m}^{3}\right)\end{array}$ & Same as primary & \\
\hline $\mathrm{Pb}$ & $\begin{array}{l}\text { Maximum quarterly } \\
\text { average }\end{array}$ & $1.5 \mu \mathrm{g} / \mathrm{m}^{3}$ & Same as primary & \\
\hline
\end{tabular}

a Parenthetical value is an approximately equivalent concentration.

b TSP was the indicator pollutant for the original particulate matter (PM) standards. This standard has been replaced with the new $\mathrm{PM}_{10}$ standard and is no longer in effect. New PM standards were promulgated in 1987, using $\mathrm{PM}_{10}$ (particles less than $10 \mu \mathrm{m}$ in diameter) as the new indicator pollutant. The annual standard is attained when the expected annual arithmetic mean concentration is less than or equal to $50 \mathrm{\mu g} / \mathrm{m}^{3}$; the 24-hour standard is attained when the expected number of days per calendar year above $150 \mathrm{\mu g} / \mathrm{m}^{3}$ is equal to or less than 1 , as determined in accordance with Appendix $\mathrm{K}$ of the PM NAAQS.

c The EPA proposed a consent decree for settlement of a citizen suit brought by the Environmental Defense Fund to compel the EPA to review and revise the NAAQS for $\mathrm{SO}_{2}$; the decree would require the EPA to take final action by August 15, 1993, on pending secondary standa'ds (57 Fed.Reg. 44375 [Sept. 25, 1992]).

d Not to be exceeded more than once per year.

- The standard is attained when the expected number of days per calendar year with maximum hourly average concentrations above $0.12 \mathrm{ppm}$ is equal to or less than 1 , determined in accordance with Appendix $\mathrm{H}$ of the ozone NAAQS. The EPA decided in August 1992 that revisions of the primary and secondary standards for ozone are not appropriate (57 Fed.Reg. 35542 [Aug. 10, 1992]).

Sources: EPA (1991); Federal Register. 
Electric utilities are also subject to the controls that apply to these emissions in attainment areas under the program to prevent significant deterioration (PSD). Principal among the values to be protected is the visibility of Class I areas, which could be impacted by these pollutants.

\subsubsection{Controls on $\mathrm{PM}_{10}, \mathrm{SO}_{2}, \mathrm{NO}_{2}$, and $\mathrm{NO}_{\mathrm{x}}$ in Nonattainment Areas}

States containing nonattainment areas - and, in the case of ozone, states that are within ozone transport regions - are required to submit SIPs in order to demonstrate how they will bring any nonattainment area(s) into attainment by the deadline mandated for each nonattaining pollutant. The principles to be used in NAAQS attainment are set out in the EPA's General Preamble. ${ }^{31}$

The CAAA established classifications for nonattaining areas by the degree of nonattainment; the different classifications are assigned different compliance deadlines, major source classifications, and offset requirements. In addition, the classifications are different for each criteria pollutant. Although the responsibility remains with the state to devise the strategy for meeting each of the standards in its SIP, Title I sets certain minimum requirements that state programs must incorporate into their plans.

$\mathbf{P M}_{10}$ Provisions. Nonattainment areas for $\mathrm{PM}_{10}$ are divided into two classes, moderate and serious areas. ${ }^{32}$ The SIPs for PM $_{10}$ must provide for attainment of the primary $\mathrm{PM}_{10}$ standards as expeditiously as practicable but, in the case of moderate areas, no later than six years from the date of nonattainment designation and, in the case of serious areas, no later than December 31, 2000. Sources of $\mathrm{PM}_{10}$ in moderate areas are required to implement reasonably available control measures (RACMs). Sources of $\mathrm{PM}_{10}$ in serious areas are required to implement best available control measures (BACMs), and sources of $\mathrm{PM}_{10}$ that emit greater than 70 tons/yr are considered major sources. (See Table 1.2.)

$\mathrm{SO}_{2}$ Provisions. Nonattainment areas for $\mathrm{SO}_{2}$ are not divided into classes of areas. ${ }^{33}$ The SIPs for $\mathrm{SO}_{2}$ must provide for atiainment of the primary $\mathrm{SO}_{2}$ standard as expeditiously as practicable but no later than five years from the date of nonattainment designation. No technology-based standards are required.

3157 Fed.Reg. 13498 (April 16, 1992) (proposed rule); 57 Fed.Reg. 18070 (April 28, 1992) (appendixes to proposed rule); 57 Fed.Reg. 55620 (Nov. 25, 1992) (supplement to General Preamble regarding $\mathrm{NO}_{\mathrm{x}}$ RACT (reasonably available control technology), NSR (new source review), interaction of Titles $\mathrm{I}$ and IV, and $\mathrm{O}_{3}$ transport).

Section 105 of the CAAA, codified at Sections $188-190$ of the Act.

33 Section 106 of the CAAA, codified at Sections 191-192 of the Act. 
TABLE 1.2 PM $_{10}$ Nonattainment Provisions ${ }^{a}$

\begin{tabular}{llll}
\hline Category & Basis for Classification & Deadline to Attain & $\begin{array}{c}\text { Technology } \\
\text { Standard }\end{array}$ \\
\hline Serious & $\begin{array}{l}\text { Those that cannot meet } \\
\text { attainment date for } \\
\text { moderate nonattainment } \\
\text { are reclassified }\end{array}$ & $\begin{array}{l}\text { Ten years from } \\
\text { redesignation, but not } \\
\text { after Dec. 31, 2001 }\end{array}$ & BACM \\
Moderate & $\begin{array}{l}\text { All nonattainment areas } \\
\text { initially }\end{array}$ & $\begin{array}{l}\text { Six years from } \\
\text { designation as } \\
\text { nonattainment }\end{array}$ & RACM \\
\hline
\end{tabular}

a Section 188 of the Act.

b $\mathrm{BACM}=$ best available control measure; $\mathrm{RACM}=$ reasonably available control measure (Section 105 of CAAA and Section 190 of the Act).

$\mathrm{NO}_{2}$ Provisions. As with $\mathrm{SO}_{2}$, nonattainment areas for $\mathrm{NO}_{2}$ are not divided into classes of areas. ${ }^{34}$ The SIPs for $\mathrm{NO}_{2}$ must provide for attainment of the primary $\mathrm{NO}_{2}$ standard as expeditiously as practicable but no later than five years from the date of nonattainment designation. No technology-based standards are required, but they are required under Title I pursuant to the $\mathrm{O}_{3}$ provisions.

$\mathrm{O}_{3}$ Control Strategies Involving $\mathrm{NO}_{\mathrm{x}^{*}}$ As with $\mathrm{PM}_{10}$, the CAAA classify nonattainment areas. The classification for $\mathrm{O}_{3}$ is more complex than that used for $\mathrm{PM}_{10}$. (See Table 1.3.) States were required to submit revised SIPs to meet the $\mathrm{O}_{3}$ control requirements by November 15, 1992.

The CAAA recognize that $\mathrm{NO}_{\mathrm{x}}$ acts as a precursor to $\mathrm{O}_{3}$ and provide that major sources of $\mathrm{NO}_{\mathrm{x}}$ will be subject to the same requirements as major sources of VOCs, except in those few cases where net air quality is better in the absence of $\mathrm{NO}_{x}$ reduction. ${ }^{35}$ Each SIP for states containing certain $\mathrm{O}_{3}$ nonattainment areas and throughout any $\mathrm{O}_{3}$ transport region must include definitions of reasonably available control technology (RACT) as part of its

34 Section 106 of the CAAA, codified at Sections 191-192 of the Act. For clarification, it should be noted that the CAAA address $\mathrm{NO}_{2}, \mathrm{SO}_{2}$, and $\mathrm{Pb}$ together in the same provisions.

35 Congress's concern about the precursor relationship was later underscored by a report prepared by the National Research Council, Rethinking the Ozone Problem in Urban and Regional Air Pollution (1991). 
TABLE 1.3 Ozone Nonattainment Provisions ${ }^{a}$

\begin{tabular}{llccc}
\hline Category & $\begin{array}{c}\text { Design Value } \\
(\mathrm{ppm})\end{array}$ & $\begin{array}{c}\text { Deadline } \\
\text { to Attain } \\
(\mathrm{yr})\end{array}$ & $\begin{array}{c}\text { Najor } \\
\text { Sources } \\
\text { (tons) }\end{array}$ & $\begin{array}{c}\text { Offset } \\
\text { Ratios }\end{array}$ \\
\hline Extreme & $>0.280$ & 20 & 10 & $1.5: 1$ \\
Severe & $0.180-0.280$ & $15-17$ & 25 & $1.3: 1$ \\
Serious & $0.160-0.180$ & 9 & 50 & $1.2: 1$ \\
Moderate & $0.138-0.160$ & 6 & 100 & $1.15: 1$ \\
Marginal & $0.121-0.138$ & 3 & 100 & $1.1: 1$ \\
\hline
\end{tabular}

a Section 182 of the Act.

strategy to attain the NAAQS for $\mathrm{O}_{3}{ }^{36}$ For all classes of nonattainment areas, major existing $\mathrm{NO}_{\mathrm{x}}$ sources must therefore implement RACT. The RACT requirements for major sources must be implemented by May 1995. ${ }^{37}$ The RACT standards for $\mathrm{NO}_{\mathrm{x}}$ control will apply to a significant number of utility units.

The EPA has issued RACT control requirements for classes of utility boilers, ${ }^{38}$ as indicated in Table 1.4. ${ }^{39}$ The limits would be calculated on a 30-day rolling average. Several sources have indicated that the low- $\mathrm{NO}_{\mathbf{x}}$ burner technology emission limits, as specified in Section 407, were lenient and that more stringent limits on $\mathrm{NO}_{\mathrm{x}}$ emissions from utility boilers could be achieved. In addition, those states with widespread ozone nonattainment difficulties and environmentalists have indicated that $\mathrm{NO}_{\mathrm{x}}$ RACT standards with emission levels similar to the $\mathrm{NO}_{\mathrm{x}}$ standards in Title IV would make the goal of attainment more difficult to achieve (Utility Environment Reporter 1992).

36 See Sections $172(c)$ and $182(b)(2)$ generally. Section $182(f)$ requires states to apply the same requirements to major stationary sources of $\mathrm{NO}_{\mathbf{x}}$ as are applied to major stationary sources of VOCs. The RACT requirements for major sources in attainment or unclassified portions of $\mathrm{O}_{3}$ transport regions originate in Section $184(\mathrm{~b})(2)$.

37 Section 182(b)(2).

38 For $\mathrm{NO}_{2}$, sources in attainment or unclassified areas are considered major if more than 100 tons of $\mathrm{NO}_{2}$ is emitted per year.

39 The EPA has proposed special rules for $\mathrm{NO}_{\mathrm{x}}$ attainment, State Implementation Plans; Nitrogen Oxides Supplement to the General Preamble for the Implementation of Title I of the Clean Air Act Amendments of 1990 (57 Fed.Reg. 55620 [Nov. 25, 1992]). 
TABLE 1.4 EPA-Proposed RACT Standards for Utility Boilers

\begin{tabular}{ll}
\hline \multicolumn{1}{c}{ Boiler Type } & $\begin{array}{c}\mathrm{NO}_{\mathrm{x}} \text { Limit } \\
(\mathrm{lb} / \mathrm{mmBtu})\end{array}$ \\
\hline Tangentially fired, coal burning & 0.45 \\
Dry bottom wall-fired (other than & \\
cell burner), coal burning & 0.5 \\
Tangentially fired, gas/oil burning & 0.2 \\
Wall-fired, gas/oil burning & 0.3 \\
\hline
\end{tabular}

STAPPA/ALAPCO, ${ }^{40}$ NESCAUM,${ }^{41}$ and recently issued state SIPs have suggested lower $\mathrm{NO}_{\mathrm{x}}$ RACT standards for utility boilers (STAPPA/ALAPCO 1992). STAPPA/ALAPCO proposes the $\mathrm{NO}_{\mathrm{x}} \mathrm{RAC} \Gamma$ standards be implemented in two phases. Phase I would begin by June 1995, and Phase II would begin no later than May 2000. Based on a 24-hour rolling average for coal units and a 1-hour averaging period for oil and gas units, the suggested emission limits for utility boilers are summarized in Table 1.5.

In Phase II, if greater $\mathrm{NO}_{\mathrm{x}}$ reductions are required, standards would be tightened further (suggested $\mathrm{NO}_{\mathrm{x}}$ limits of $0.05 \mathrm{lb} / \mathrm{mmBtu}$ for oil-fired and gas-fired boilers and $0.2 \mathrm{lb} / \mathrm{mmBtu}$ for coal-fired boilers). STAPPA/ALAPCO supports the use of plant-level emissions averaging as a way of avoiding high-cosi controls. ${ }^{42}$ NESCAUM's initially released $\mathrm{NO}_{\mathrm{x}} \mathrm{RACT}$ requirements were more stringent for dry bottom, tangentially, and wall-fired boilers but have been relaxed and are now identical to those of STAPPA/ALAPCO (Utility Environment Reporter 1992). The New York Department of Environmental Conservation (DEC) has issued $\mathrm{NO}_{\mathrm{x}}$ RACT limits similar to those of NESCAUM, except alternate limits were issued for dry bottom wall-fired coal boilers and coal-fueled dry bottom stokers. ${ }^{43}$ The NESCAUM and New York limits presume the combustion modification procedures of overfire

40 State and Territorial Air Pollution Program Administrators and the Association of Local Air Pollution Control Officials.

41 Northeast States for Coordinated Air Use Management.

42 STAPPA/ALAPCO bases its suggestions on examination of $\mathrm{RACT}_{\mathrm{NO}}$, boiler requirements in the South Coast Air Quality Management District, the Ventura County Air Quality Management District, standards indicated by NESCAUM, studies of Wisconsin and Georgia, and other engineering analysis. Its recommendations include the use of overfire air technology and advanced overfire air technology. The Phase II limits are based on additional combustion modification or controls, including selective catalytic reduction and selective noncatalytic reduction.

43 See NYCRR 6-227-5. Dry bottom, wall-fired coal boilers have an $\mathrm{NO}_{\mathrm{x}}$ limit of $0.43 \mathrm{lb} / \mathrm{mmBtu}$, and stokers have a limit of $0.3 \mathrm{lb} / \mathrm{mmBtu}$. 
TABLE 1.5 STAPPAALAPCO-Recommended NO RACT $_{x}$ for Utility Boilers

\begin{tabular}{|c|c|c|c|c|}
\hline \multirow[b]{2}{*}{ Fuel Boiler } & \multicolumn{4}{|c|}{$\mathrm{NO}_{\mathrm{x}} \mathrm{RACT}(\mathrm{lb} / \mathrm{mmBtu})$} \\
\hline & $\begin{array}{c}\text { Tangentially } \\
\text { Fired }\end{array}$ & $\begin{array}{l}\text { Wall- } \\
\text { Fired }\end{array}$ & Cyclone & Stoker \\
\hline Natural gas & 0.2 & 0.2 & $\mathrm{n} / \mathrm{a}$ & $\mathrm{n} / \mathrm{a}$ \\
\hline Natural gas/oil & 0.25 & 0.25 & 0.43 & $\mathrm{n} / \mathrm{a}$ \\
\hline Coal, wet bottom & 1.0 & 1.0 & 0.55 & $\mathrm{n} / \mathrm{a}$ \\
\hline Coal, dry bottom & 0.38 & 0.38 & $\mathrm{n} / \mathrm{a}$ & 0.4 \\
\hline
\end{tabular}

air, advanced overfire air, and biased burner firing and burners out of service methods to achieve the RACT standard. ${ }^{44}$ While the EPA considers its recommendations to be appropriate, states do have the option to issue stricter requirements if they believe that current standards would not allow for progress toward attainment goals.

To address the issue of multistate transport of ozone, Section 176A provides for the establishment of ozone transport regions (OTRs). All major sources within an OTR, whether the source is in an attainment, nonattainment, or unclassifiable area, must meet new source review (NSR) and RACT requirements. Section 184(a) creates an OTR covering Connecticut, Delaware, Maine, Maryland, Massachusetts, New Hampshire, New Jersey, New York, Pennsylvania, Rhode Island, Vermont, and the Central Metropolitan Statistical Area (CMSA) containing the District of Columbia.

\subsubsection{Controls on $\mathrm{PM}_{10}, \mathrm{SO}_{2}$, and $\mathrm{NO}_{2}$ in Attainment Areas - PSD/Visibility}

In the 1977 amendments to the CAA, Congress adopted a program to prevent significant deterioration of air quality in attainment areas. ${ }^{45}$ In essence, this provision

44 See NESCAUM Stationary Source Recommendation of $\mathrm{NO}_{\mathrm{x}}$ RACT for Utility Boilers (letter dated March 25, 1992).

45 The PSD program is unique in air quality regulation as having wholly originated in the courts as a result of litigation. In a suit brought by the Sierra Club, the courts interpreted the statutory provisions for attainment of the NAAQS in light of Section 101(b)(1) of the CAA, which stated a corresponding requirement to "protect and erihance" air quality. They interpreted the two provisions as requiring protection of already-clean air quality areas (Sierra Club v. Ruckelshaus, 344 F.Supp. 253 [D.D.C. 1972], affd per curiain without opinion [D.C. Cir. 1972], affd by an equally divided Court, 412 U.S. 541 [1973]). The Sierra Club was able to convince the court that these provisions, when read together, required the EPA to establish a program to prevent a deterioration of air quality in these areas. Pursuant to the Sierra Club decision, the EPA adopted regulations in 1974 (39 Fed.Reg. 42510). The PSI) provisions were codified as Title I, Part C of the Act, Sections 160-169A of the Clean Air Act, 42 U.S.C. $\$ \$ 7470-7491$. 
provided a way to prevent states from moving pollution sources into already-clean areas as their strategy to meet ambient standards for criteria pollutants.

The 1977 Act divided attainment areas into three classes. Class I areas, for which the greatest protection was offered, include all large national parks and wilderness areas, most of which are west of the Mississippi River. All other attainment areas are Class II. No area has ever been redesignated as Class III.

The CAA contains two distinct approaches for protecting air quality in Class I areas. The first approach, which works through the PSD program, contains two components, preconstruction review and technology-based standards.

As a general rule, no new major source may be constructed and no existing major source modified without a permit that demonstrates that emissions from it will not exceed or contribute to the exceedence of air-quality-related values, NAAQSs, or any other standards under the CAA. While visibility is the only air-quality-related value specified by the CAA, other values, such as acid deposition to streams, are contemplated by the CAA (Loeb and Elliott, in press). The 1990 amendments left the substance of the 1977 provisions intact but changed the process by including the PSD permitting process within the new Title V permit program.

The CAA establishes two tests used to judge the impact of a proposed facility upon the Class I area:

1. The Class I increment test establishes the extremely small amounts of additional particulate and $\mathrm{SO}_{2}$ emissions that Congress believed, as a general rule, can be allowed in Class I areas. ${ }^{46}$ The EPA regulations reiterate the statutory maxima for $\mathrm{SO}_{2}$ and particulates ${ }^{47}$ and, in addition, add maximum allowed increments for $\mathrm{NO}_{2} \cdot{ }^{48}$ (See Table 1.6.)

2. Congress realized, however, that, in some instances, certain resources could be affected by air pollution increases below the Class I increments and provided for an adverse impact test. If the federal land manager (FLM) demonstrates to the satisfaction of the permitting authority that proposed emissions from new or modified facilities will adversely impact the air-quality-related values of a

46 Section $163($ b) of the Act.

47 The EPA changed the indicator pollutant from PM to $\mathrm{PM}_{10}$ at 58 Fed.Reg. 31622 (June 3, 1993).

48 The $\mathrm{NO}_{2}$ increments were issued at 53 Fed.Reg. 40656 (Oct. 17, 1988) to comply with Sierra Club v. Thomas, 658 F.Supp. 165 (N.D. Cal. 1987), which compelled the EPA to meet the requirements of Section 166(a) of the Act, 42 U.S.C. $\$ 7476$ (a) and 40 CFR $\$ 51.166(c)$. 
TABLE 1.6 Maximum Pollutant Increments for Class I and Class II Areas ${ }^{\mathrm{a}}$

\begin{tabular}{|c|c|c|c|c|}
\hline \multirow[b]{2}{*}{ Pollutant } & \multicolumn{2}{|c|}{ Class I Areas } & \multicolumn{2}{|c|}{ Class II Areas } \\
\hline & Averaging Time ${ }^{b}$ & $\begin{array}{c}\text { Standard } \\
\text { Level } \\
\text { Concentration } \\
\left(\mu \mathrm{g} / \mathrm{m}^{3}\right)\end{array}$ & Averaging Time ${ }^{b}$ & $\begin{array}{c}\text { Standard } \\
\text { Level } \\
\text { Concentration } \\
\left(\mu \mathrm{g} / \mathrm{m}^{3}\right)\end{array}$ \\
\hline $\mathrm{PM}_{10}^{\mathrm{c}}$ & $\begin{array}{l}\text { Annual arithmetic } \\
\text { mean } \\
\text { 24-hour }\end{array}$ & $\begin{array}{l}4 \\
8\end{array}$ & $\begin{array}{l}\text { Annual arithmetic } \\
\text { mean } \\
\text { 24-hour }\end{array}$ & $\begin{array}{l}17 \\
30\end{array}$ \\
\hline $\mathrm{SO}_{2}$ & $\begin{array}{l}\text { Annual arithmetic } \\
\text { mean } \\
\text { 24-hour } \\
\text { 3-hour }\end{array}$ & $\begin{array}{c}2 \\
5 \\
25\end{array}$ & $\begin{array}{l}\text { Annual arithmetic } \\
\text { mean } \\
\text { 24-hour } \\
\text { 3-hour }\end{array}$ & $\begin{array}{c}20 \\
91 \\
512\end{array}$ \\
\hline $\mathrm{NO}_{2}$ & $\begin{array}{l}\text { Annual arithmetic } \\
\text { mean }\end{array}$ & 2.5 & $\begin{array}{l}\text { Annual arithmetic } \\
\text { mean }\end{array}$ & 25 \\
\hline
\end{tabular}

a Standards also exist for Class III areas, but these are omitted here, since no Class III areas exist.

b For any period other than an annual period, the applicable maximum allowable increase may be exceeded during one such period per year at any one location.

c The standard was changed from PM to $\mathrm{PM}_{10}$ at 58 Fed.Reg. 31622 (June 3, 1993).

Source: 40 CFR \& 51.166(c).

Class I area, then the permitting authority may not authorize the proposed project. ${ }^{49}$ On the other hand, if the proposed facilities violate the increments, the facilities can be permitted only if the lack of adverse impact is proved to the FLM's satisfaction.

In addition to the permit requirement, all major sources are subject to technology-based control requirements for each pollutant regulated under the CAA. All new major sources and major modifications of existing sources are required to use the "best available control technology" (BACT); ${ }^{50}$ nonmajor new sources are exempt from preconstruction review and BACT, although they are subject to applicable NSPSs.

49 Section $165(\mathrm{~d})(2)(\mathrm{C})(\mathrm{ii})$.

50 Section $169(3)$ of the Act. The BACT requirement is at least as stringent as an NSPS but only as strict as a lowest achievable emission rate (LAER) if the state imposes it (National Research Council, On Prevention of Significant Deterioration of Air Quality [1981]). 
Under the second approach, the 1977 amendments set a national goal of preventing any future, and remedying any existing, man-made visibility impairment in Class I areas. ${ }^{51}$ To achieve this goal, each state that contains a Class I area or any source of emissions that may cause or contribute to visibility impairment in such an area must submit a SIP describing how the state will make reasonable progress toward achieving the national visibility goal. The SIP must include (1) long-term strategies to achieve reasonable progress and (2) "best available retrofit technology" (BART) standards for those major existing sources that contribute to visibility impairment. ${ }^{52}$ The EPA regulations require that affected states set BART standards for each stationary source facility that may affect visibility in Class I areas; ${ }^{53}$ however, for fossil-fuel-fired generating plants with capacities greater than $750 \mathrm{MW}$, the applicable BART standard is determined pursuant to the EPA's own guidance. ${ }^{54}$

Under provisions added by the 1990 amendments, the administrator of the EPA is required to consider revising the visibility program according to studies of visibility impairment ${ }^{55}$ and reports issued by the visibility transport commissions. ${ }^{56}$ These provisions

51 The Clean Air Act $\S \S 160(2)$ and $169 A(a)(1), 42$ U.S.C. $\$ \S 7470(2)$ and $7491(a)(1)$ (1977). See 40 C.F.R. Part 51, Subpart P (1980). The EPA has defined "adverse impact on visibility" at 40 C.F.R. $\S 51.301$ (a) (1980). The EPA defines "visibility impairment" as "any humanly perceptible change in visibility (visual range, contrast, coloration) from that which would have existed under natural conditions" [40 C.F.R. § 51.301(x) (1980)].

52 Id., $\S 169 \mathrm{~A}(\mathrm{~b})(2), 42$ U.S.C. $\S 7491(\mathrm{~b})(2)$ (1977), as implemented by 40 C.F.R. $\S 51.300$ et seq. (1980). See Conference Report to accompany S. 1630, Report 101-952 (101st Congress, 2d Session) (1990), at 1535 . "Major stationary source" is defined at $I d ., \S 169 \mathrm{~A}(\mathrm{~g})(7), 42$ U.S.C. $\S 7491(\mathrm{~g})(7)$ (1977), as implemented by 40 C.F.R. $\$ 51.301(p)(1980)$.

40 C.F.R. $\$ 51.302(c)(4)(i)$.

54 The Clean Air Act $\S \S 169 \mathrm{~A}(\mathrm{~b})$ and (c)(2), 42 U.S.C. $\S \S 7491 \mathrm{~A}(\mathrm{~b})$ and (c)(2) (1977), as implemented by 40 C.F.R. $\S \S 51.301(\mathrm{c})$ and $51.302(\mathrm{c})(3)(1980)$. The regulations require states to use the EPA Guidelines for Determining Best Available Retrofit Technology for Coal-fired Power Plants and Other Existing Stationary Facilities (1980). Exemptions may be made by the state for cause [40 C.F.R. § 51.303(b) (1980)].

55 The EPA was required to assess the improvements in visibility in Class I areas likely to result from implementation of other provisions of the 1990 amendments and report within two years of enactment [Clean Air Act § 169B(b), 42 U.S.C. § 7412(b) (1990)].

56 Visibility transport commissions are required to study adverse impacts potentially resulting from growth in emissions from sources in a visibility transport region and to produce reports and recommendations on remedies for such impacts [The Clean Air Act $\S \S 169 \mathrm{~B}(\mathrm{~d})(1)$ and (d)(2), 42 U.S.C. $\S \S 7492(d)(1)$ and (d)(2) (1990)]. Visibility transport commissions are required to be established whenever the administrator establishes a visibility transport region [The Clean Air Act $\S 169 \mathrm{~B}(\mathrm{c})(2), 42$ U.S.C. $\S 7492(\mathrm{c})(2)(1990)]$. The only transport commission to be formed so far is the one expressly required under the 1990 amendments, so the impacts of this process will be limited in the short term to the Grand Canyon region; however, additional regional commissions may soon be forthcoming; for example, in June 1992, eight southeastern states formed a coalition, the Southern Appalachian Mountain Initiative (SAMI), in recognition of the interstate transport 
create the potential for future changes in the visibility program by redefining how much progress is reasonable. ${ }^{57}$

Initially, the PSD/visibility program did not constrain utility siting decisions, but, over time, the Class I increments have been consumed, so that FLMs have begun to anticipate the exhaustion of the available increments, and these become constraints in situations where they were not in the past. Thus, the first applicant for a permit may consume many of the legally available increments, preventing approval of later applications. In addition, in the last several years, the FLMs have adopted more activist policies, taking the position that the Class I increment test does not sufficiently protect Class I areas. In 1990, for the first time, an FLM issued a determination that a coposed power plant would have an adverse impact upon air-quality-related values. ${ }^{58}$ Then, in October 1992, the EPA overruled a state permitting authority for failure to consider an FLM determination of adverse impact. ${ }^{59}$

Thus, visibility will play a larger role in regions of the country where power plant emissions may affect Class I air quality. The visibility provisions are going to have an increasing impact on utility planning decisions for new sources. The visibility constraints will likely cause utilities to site plants farther from Class I areas and force longer transmission to power consumers, affect fuel type and technology used, and put pressure on states to use offsets for new plants in order to mitigate the increased costs (Loeb and Elliott, in press).

\subsubsection{Title III Hazardous Air Pollutant Controls}

Prior to the 1990 Act, no federal controls of HAPs were required for fossil-fuel steam generating units. ${ }^{60}$ The 1990 CAAA establish an elaborate system of emission control, but controls of utility HAP emissions are pending the outcome of studies.

${ }^{56}$ (...continued)

of pollutants to Class I areas in that region, particularly the Great Smoky Mountains and Shenandoah National Parks (Eight States To Target Measures Remedying Pollution Impacts, Clean Air Report [Ins. Wash. Pub] 4 [July 15, 1993]). SAMI has received a total of $\$ 625,000$ in funding from the EPA and Congress (Id., at 5). Groups such as SAMI may evolve into visibility transport regions.

57 See Central Arizona Water Conservation District v. EPA, 36 ERC 1177 (9th Cir. 1993), cert. denied, 114 S.Ct. 94 (1993).

58 "Preliminary Notice of Adverse Impact on Shenandoah National Park," 55 Fed.Reg. 38403 (Sept. 18, 1990), at 38408.

59 In the Matter of Hadson Power 14-Buena Vista, PSD Appeal Nos. 92-3, 92-4, 92-5 (Oct. 5, 1992).

60 Several states do regulate HAP emissions from new and existing sources. See Loeb, A.P., et al., 1992, Air Toxics Provisions of the Clean Air Act Amendments: Regulatory Issue Analysis, Argonne National Laboratory Internal Report. 
With regard to industrial sources, Title III of the CAAA identifies pollutants and places their sources on a schedule for regulation. The sources listed pursuant to Section $112(c)(1)^{61}$ will first become subject to maximum available control technology (MACT) requirements, ${ }^{62}$ and then eight years later, the success of the MACT standards in reducing risk will be evaluated by tha EPA to determine if additional controls are needed to prevent adverse impacts on health and the environment. ${ }^{63}$

The MACT standard requires application of technology that is not less stringent than that which is achieved by best controlled similar sources. ${ }^{64}$ For existing sources, the MACT technology may be less stringent than that for new sources but must achieve the average emission limit by the best performing $12 \%$ of existing sources for categories with 30 sources or greater or the average emission limit achieved by the best performing five sources for a category containing less than 30 sources. ${ }^{65}$ The use of MACT is mandatory for those point sources emitting over 10 tons per year (tpy) of a particular HAP or over 25 tpy of a combination of HAPs. These sources are known as major sources. Sources emitting less than these amounts are known as area sources, for which the EPA has flexibility regarding the issuance of controls on these sources and flexibility regarding the level of control required. ${ }^{66}$

By contrast, utility fossil-fuel generating units are specifically exempt from the source categories. Electric utility units are subject to special studies to determine if controls are needed. ${ }^{67}$ Three studies regarding utility fossil-fuel steam generation units are required to assess if HAP controls are needed. ${ }^{68}$ Under the statute, the EPA must report on the hazards to public health and on control strategies that could reduce those emissions by November 1993. Also by November 1993, the National Institute of Environmental Health Sciences (NIEHS) was to report on the threshold at which $\mathrm{Hg}$ exposure affects human health. By November 1994, the EPA is required to report the level of $\mathrm{Hg}$ emissions from utility fossilfuel steam units, the impact of $\mathrm{Hg}$ loadings from utility sources on health and the

61 Section $112(c,(1)$.

62 Section 112(e)(2) requires the EPA to rank the source categories based on the known or anticipated adverse effects of these sources on health and the environment. At least 40 categories were required to have standards issued by November 1992, and all sources must have standards established by November 2000 .

63 Section $112(f)(1)$.

64 Section $112(d)(3)$.

65 Section $112(d)(3)$.

66 Section $112(c)(1)$.

67 In addition, coke oven batteries, solid-waste combustion units, and utility fossil-fuel steam generation units are subject to special rules and studies.

68 Section 112(n)(1). 
environment, and the availability and cost of control. ${ }^{69}$ From these data, the EPA will make a judgment whether utility fossil-fuel steam generators require regulation of HAP emissions. If compliance requirements are similar to those of the "standard" MACT program, compliance with MACT regulations will be required three years after the standard is issued.

At present, the impact of Title III on utility $\mathrm{SO}_{2}$ compliance choice is uncertain. Potential cost-reducing compliance measures under Title III, such as early emissions reductions $^{70}$ and netting of HAP emissions to avoid MACT for modified sources, ${ }^{71}$ may be allowed for utilities. Early reduction of HAP emissions of at least 90\% (95\% if HAPs are particulates) allows for a six-year delay in compliance with the MACT standards and allows the trading of emissions reductions between HAP forms based on EPA-established ratios. If a control option such as BACT or the lowest achievable emission rate (LAER) for the particular HAP is implemented on an existing source before the MACT standard is issued, the source receives an additional five years to comply with MACT requirements.

\subsubsection{New Source Performance Standards for $\mathrm{SO}_{2}$ and $\mathrm{NO}_{x}$ Emissions}

Under Section 111 of the CAA of 1970, the EPA is required to list categories of new stationary sources that cause or contribute to air pollution and to promulgate NSPSs for such categories. ${ }^{72}$

In the early years, from 1971 to 1974 , the EPA prioritized those industries that generated large amounts of emissions and presented significant dangers to human health, including the eler ic utility industry, ${ }^{73}$ incinerators, nitric and sulfuric acid plants, and cement makers. By 1974, regulations had been issued for the majority of these industries, and the EPA turned to process industries, such as smelters, steel makers, and refineries. The early rules controlled primarily $\mathrm{SO}_{2}, \mathrm{NO}_{\mathbf{x}}$, and TSPs; however, the NSPS program was accused of failing to force the EPA to issue the required regulations.

The 1977 amendments set out a timetable for issuance of standards to expedite the EPA's promulgation of standards. Several additional industries were regulated soon afterwards, concentrating on TSPs and VOCs to reduce urban smog. The "coating" industries, along with mineral processing facilities, received a majority of the industrial source regulation from 1977 to 1982 . In addition, new utility construction after 1978 was further regulated, requiring more stringent control standards.

69 The EPA has announced that it will not meet the statutory deadlines and that the likely delivery dates are in 1995.

70

Section 112(i)(5).

71 Section 112(g).

72 The EPA's NSPS regulations are codified at 40 CFR Part 60.

73

See Sierra Club v. Costle, 657 F.2d 298 (D.C. Cir. 1981). 
Under Section 407(c)(1), the EPA is required to propose revised NSPSs under Section 111 for $\mathrm{NO}_{\mathrm{x}}$ for fossil-fueled steam generation units by January 1, 1993, and finalize them by January 1,1994 . No rules have been formally proposed yet by the EPA. While this will create momentum for greater $\mathrm{NO}_{\mathrm{x}}$ reduction, the amount of actual reduction may be only marginal. The NSPSs affect only new sources, by definition. With the Title IV and Title I $\mathrm{NO}_{\mathrm{x}}$ programs already underway and the EPA vowing to coordinate the $\mathrm{NO}_{\mathrm{x}}$ programs under the various titles, it is probable that the NSPS $\mathrm{NO}_{\mathrm{x}}$ program will present constraints on utility compliance choices only in a few, discrete situations.

\subsubsection{Regulation of Solid and Aqueous Waste}

Fossil-fuel combustion at electric utilities produces several by-products. In addition to the air emissions, utilities produce solid and aqueous wastes that can be categorized as either "high-volume" or "low-volume" combustion wastes. High-volume combustion wastes consist of bottom ash, fly ash, slag, and, if a scrubber unit is present, flue gas desulfurization (FGD) sludge. High-volume wastes are produced on a continuous basis. Low-volume wastes consist primarily of boiler cleaning liquids, water treatment chemicals, equipment cleaning wastes, and brines. Low-volume wastes tend to be produced on a periodic basis and are associated with routine maintenance and wastewater processing.

In 1988, the EPA issued the report Wastes from the Combustion of Coal by Electric Utility Power Plants, which indicated that high-volume combustion wastes tend to be nonhazardous and that current disposal practices are appropriate (EPA 1988). States can issue regulations regarding the treatment of high-volume combustion wastes, and future regulation could reverse the nonhazardous disposal practices of approximately 85 million tons of utility waste produced each year (Utility Environment Reporter 1992). The EPA has recently ruled that high-volume combustion wastes are not to be classified as hazardous under Subtitle $\mathrm{C}$ of the RCRA, removing the risk of federal hazardous waste treatment requirements (Utility Environment Reporter 1993).

High-volume combustion wastes are presently treated and disposed of in ash and sludge ponds. Some of the wastes have also been used in commercial applications, such as road-fill, concrete, asphalt-pavement, and masonry applications. Commercial applications of the wastes save the utility industry millions of dollars per year in disposal costs (Power Engineering 1992). Further increases in the use of nonhazardous high-volume combustion waste and advancement in waste recovery technologies will generate even larger savings for the utility industry and reduce landfill space requirements.

A secondary issue to the choice of $\mathrm{SO}_{2}$ control technology will be the treatment of low-volume combustion wastes. Low-volume combustion wastes account for only $1 \%$ of the total waste volume, and the relative impact on $\mathrm{SO}_{2}$ compliance choice is not expected to be 
large. ${ }^{74}$ Low-volume combustion wastes do contain high levels of many regulated heavy metals and other chemicals whose concentrations exceed regulated allowed levels. In addition, coal pile runoff associated with eastern bituminous coals contains large amounts of heavy metals (EPRI 1992). At present, these wastes are not regulated under the RCRA, although regulations are expected to be promulgated. The Electric Power Research Institute (EPRI) has conducted two studies examining the commingling of these wastes with highvolume combustion wastes in ash and sludge ponds (EPRI 1992). In EPRI's examination of the present commingling treatment, none of the hazardous trace elements were found to exceed regulatory standards in the surrounding groundwater.

Related to solid and aqueous combustion wastes are land-use impacts associated with alternative $\mathrm{SO}_{2}$ compliance methods. Steam electric plants require a sizable acreage for siting, transmission facilities, and disposal areas for wastewater, ash, and slag. Steam electric plants also tend to be located near rivers, large streams, or lakes to readily obtain the large quantities of water for cooling and maintenance purposes and, in some cases, ease of coal deliveries (Ottinger et al. 1990). The location of a steam electric plant impacts both the aesthetic qualities of an area and the ecological function of an area.

At present, plant siting, along with its associated land-use requirements (e.g., disposal area, stacks, water intakes, and transmission facilities), has been addressed through land, water, and air permitting requirements. ${ }^{75}$ Several new coal plants have experienced significant delays due to a wide variety of permitting considerations resulting in much higher development costs. Tightening emission requirements associated with the 1990 CAAA, along with possibly stricter requirements associated with water quality, will make permitting even more difficult.

\subsubsection{Carbon Dioxide Emission Controls}

The issue of potential global climate change, as a result of increasing concentrations of greenhouse gases (GHGs), has drawn considerable attention from the scientific, environmental, and policy communities over the past decade. The principal anthropogenic contributors to global climate change are considered to be $\mathrm{CO}_{2}$, methane $\left(\mathrm{CH}_{4}\right)$, nitrous oxide $\left(\mathrm{N}_{2} \mathrm{O}\right)$, and, possibly, tropospheric ozone $\left(\mathrm{O}_{3}\right) \cdot{ }^{76}$ While evidence regarding current climatic

74 For almost all $\mathrm{SO}_{2}$ compliance options, boiler cleaning and water treatment compounds will be required.

75 Siting difficulties have caused numerous delays in plant construction. The delays have been related to "not-in-my-backyard" (NIMBY) perceptions of the local populace to electric plants, air quality considerations, water quality considerations, zoning difficulties, and wetland permitting. The siting of a facility may require an environmental assessment or an environmental impact statement, depending on the magnitude of the plant's impact.

76 Until recently, chlorofluorocarbons (CFCs) were considered to be important contributors to global warming; however, recent evidence has suggested that CFCs may have little net radiative effect and may, in fact, have a negative effect on global warming (Ramaswamy et al. 1992). 
change is uncertain, national and international bodies have examined the need to control GHG emissions (Fish and South 1993).

Electric utility combustion emissions account for approximately $30 \%$ of the total U.S. $\mathrm{CO}_{2}$ emissions (Dudeck et al. 1990). Estimated utility $\mathrm{CO}_{2}$ emissions in 1987 were 454 million metric tons (U.S. Department of Energy [DOE] 1991). Electric utilities are also responsible for methane and nitrous oxide emissions through combustion, natural gas transportation, and coal bed methane emission, although the relative share of the GHG emission to other sectors (i.e., transportation, industrial, commercial, and residential) is small. ${ }^{77}$ Given the relative prominence of electric utilities as a $\mathrm{CO}_{2}$ emission source, both the state and federal governments have either begun or proposed programs to reduce aggregate utility $\mathrm{CO}_{2}$ emissions (Fish and Elliott 1992; South et al. 1992b).

To address state-level GHG emissions, with particular emphasis on $\mathrm{CO}_{2}$, several states have developed state energy strategies. ${ }^{78}$ Those policies affecting electric utility generators are primarily accomplished through mandating intcgrated resource planning and demand-side management (DSM) programs under the regulatory jurisdiction of the state public utility commission (PUC). Local and state mandated building and efficiency codes, along with institutional energy-efficiency programs, will also affect electric utility $\mathrm{CO}_{2}$ emissions.

On the federal level, several international treaties have been ratified, as has the National Energy Strategy of 1992. Also, significant numbers of bills have been proposed in both the House and Senate that would put controls on the emissions of GHGs (Fish and Elliott 1992).

The United Nations Framework Convention on Climate Change (102-38) was ratified on September 8, 1992. ${ }^{79}$ The treaty was an outgrowth of both the Montreal Protocol of 1987 and the United Nations Conference on Environment and Development (UNCED) meetings of June 1992 in Rio de Janeiro, Brazil. The institutions and policies specified within the treaty are to take effect when at least 50 nations have approved the Framework Convention on Climate Change. The treaty's principal role would be to assess national GHG emission inventories; establish plans to transfer technology to lesser developed countries (LDCs); research atmospheric processes; and examine the environmental, economic, and social issues surrounding GHG emissions. The impact of the treaty on electric utility operations is minimal; however, the trend indicated by the treaty, along with the current political climate, may greatly affect public utility operations and $\mathrm{SO}_{2}$ compliance planning.

77 In 1987, the approximate utility (both electric and natural gas) methane emissions were 11.0 thousand metric tons out of an estimated 680.1 thousand tons (DOE 1991).

78 While many state PUCs are encouraging the adoption of DSM programs through regulatory incentives and other mechanisms, in several states, DSM expenditures are required as a percentage of total revenues earned by a utility.

79 See Fish and Elliott (1992) for a full description of the treaty. 
The Comprehensive National Energy Policy Act of $1992^{80}$ (also referred to as the National Energy Strategy Act [NES] of 1992) addresses a wide range of energy and environmental issues. ${ }^{81}$ Title XVI of the Act specifically addresses issues of global climate change. Section 1601 of the Act requires numerous reports, including the following:

- An examination of the economic, energy, social, competitive, and environmental implications of stabilizing GHG emissions by 2005 ;

- An examination of recommendations regarding Chapter 9 of the 1991 National Academy of Sciences (NAS) report on global climate change (GCC);

- A feasibility study of reducing GHGs;

- A feasibility study of reducing GHGs by $20 \%$ of the 1988 levels by 2005; and

- The implications of the United Nations Framework Convention on Climate Change (102-38) on the United States for the economy, society, energy, the environment, and competitiveness.

The reports are to be completed by October 1994.

Section 1602 requires the preparation of a national least-cost energy strategy. The national least-cost energy strategy is (1) to examine the range of energy technologies in terms of efficiency, costs, and practicability, the consequences of alternative energy plans, and the potential to stabilize GHGs; (2) to meet the goal of increasing the nation's efficiency in energy use by $30 \%$ over 1988 levels by 2010; (3) to increase the use of renewable energy; and (4) to decrease the consumption of oil. Sections 1602 (c) and 1602(d)(1-7) imply significant revisions to utility generation policy and resource acquisition. Those points of examination that could affect public utility operation include the following:

- Set standards for efficient fossil-fuel use,

- Increase energy efficiency of existing technologies,

- Encourage development of technologies that lower GHG emissions,

- Promote the use of renewable energy resources,

- Use tax policy to encourage efficient energy resources, and

- Encourage advanced nuclear generation options.

80 P.L. 102-1018.

81 The examination here is largely drawn from Fish and Elliott (1992). 
The policy tools used to implement one or more of these actions could include GHG emission taxes, technology subsidies, marketable permits, or command-and-control policies.

Section 1604 authorizes a study on both market and regulatory mechanisms that could reduce GHGs. The section emphasizes the examination of unit emission caps, emission trading, and efficiency standards programs.

The final section that could affect the utility sector is Section 1605, the National Inventory and Voluntary Reporting of Greenhouse Gases. The federal government is required to establish a national inventory and voluntary reporting guidelines. Reporting firms will assess current GHG emissions, reductions in GHGs made through factors such as heat rate improvements, DSM measures, renewable energy use, and others. While voluntary, the reporting will include reductions in GHGs. The recording of preregulation GHG emission reductions may imply that reduction of GHGs before regulation (potentially) occurs will be rewarded. ${ }^{82}$

Other policies within the 1992 Act that do not specifically address GHGs but could impact utility compliance and technology choice include the following:

- Greater energy efficiency requirements for buildings,

- Public Utility Holding Company Act reform to encourage greater competition,

- Streamlined nuclear power plant licensing,

- New energy research-and-development (R\&D) programs,

- Coal technology development programs, and

- Fiscal incentives for alternative fuels and renewable energy.

In addition to the 1992 Act and UNCED treaty, the 102nd Congress addressed numerous GCC bills. ${ }^{83}$ The basic issues examined for GCC in the 102nd Congress are summarized in Table 1.7.

82 At this point, this statement is speculative; however, other emission control programs (i.e., air toxics) allow for early emission reductions that can be exchanged for delays in or less strict compliance requirements. The $\mathrm{SO}_{2}$ program specifically rewards those states and utilities that had low $\mathrm{SO}_{2}$ emissions before the CAAA of 1990 were enacted. The possibility of reduced or delayed requirements or incentive bonus could influence compliance choices.

83 Fifteen bills with global climate change themes or policies were presented during the 102nd Congress. Only the Comprehensive National Energy Policy Act of 1992 was made law. See Fish and Elliott (1992). 
TABLE 1.7 Selected Provisions of Global Climate Change Bills in the 102nd Congress

\begin{tabular}{|c|c|c|c|c|c|c|c|c|c|c|c|}
\hline Provision & S201 & S324 & S741 & S1323 & S2166 & HR1086 & HR1583 & HR2663 & HR2960 & HR4154 & HR4722 \\
\hline $\begin{array}{l}\text { Mandatory } \mathrm{CO}_{2} \\
\text { emission offset system }\end{array}$ & & * & & * & & & & $*$ & & & \\
\hline $\begin{array}{l}\text { Tax on carbon content } \\
\text { of fossil fuels }\end{array}$ & & & & & & $*$ & & & & & \\
\hline $\begin{array}{l}\text { Tax/rebate for } \\
\text { less/more efficient } \\
\text { vehicles }\end{array}$ & $*$ & & & & & & $\mathbf{a}$ & & $\mathbf{a}$ & & \\
\hline Energy R\&D ${ }^{b}$ & & $*$ & $*$ & & $*$ & & & & & & \\
\hline $\begin{array}{l}\text { Specific energy } \\
\text { efficiency measures }^{c}\end{array}$ & & $*$ & $*$ & & $*$ & & & & & & \\
\hline $\begin{array}{l}\text { Programs to } \\
\text { encourage fuel } \\
\text { switching } d\end{array}$ & & & * & & * & & & & * & & \\
\hline $\begin{array}{l}\text { Instruction for } \\
\text { international GCC } \\
\text { policy }\end{array}$ & * & $*$ & & & & & & & & * & $*$ \\
\hline $\begin{array}{l}\text { Study effect/methods } \\
\text { of GHG reductions }\end{array}$ & & * & $*$ & & $*$ & & & & & & \\
\hline $\begin{array}{l}\text { Development of least- } \\
\text { cost energy strategye }\end{array}$ & & * & * & & $*$ & & & & & & \\
\hline $\begin{array}{l}\text { Director of climate } \\
\text { protection at DOE }\end{array}$ & & * & * & & $*$ & & & & & & \\
\hline $\begin{array}{l}\text { Special GCC-related } \\
\text { budgetary fund }\end{array}$ & & & & & & & & & & * & * \\
\hline
\end{tabular}


TABLE 1.7 (Cont.)

\begin{tabular}{|c|c|c|c|c|c|c|c|c|c|c|c|}
\hline Provision & S201 & S324 & S741 & S1323 & S2166 & HR1086 & HR1583 & HR2663 & HR2960 & HR4154 & HR4722 \\
\hline $\begin{array}{l}\text { Domestic/international } \\
\text { forestation }\end{array}$ & * & $*$ & & & & & & & & * & \\
\hline $\begin{array}{l}\text { Regulations } \\
\text { specifically for } \mathrm{CH}_{4}\end{array}$ & & * & & & & & & & & & \\
\hline $\begin{array}{l}\text { Phaseout of ozone- } \\
\text { depleting substances }\end{array}$ & & $*$ & & & $*$ & & & & & & \\
\hline
\end{tabular}

a Tax/rebate schedule based directly on $\mathrm{CO}_{2}$ emission rates, adjusted for vehicle and class size.

b Research, development, and demonstration of advanced and more energy-efficient technologies and new applications.

c Includes measures directed at energy production or consumption except for those noted above in this table.

d Refers to all sectors and generally means substituting natural gas, alternative automotive fuels, renewable energy, or nuclear power for coal or petroleum.

e Which, along with other objectives, aims to minimize GHG emissions.

Source: Fish and Elliott (1992). 
The predominant GCC provision of the various GCC bills was increased R\&D expenditures for renewable and energy-efficient technologies. Those bills (i.e., S.201, S.1323, HR.1086, and HR.2663) actively seeking to stabilize and reduce GHG emissions from the electric utility industry promote the use of either (1) $\mathrm{CO}_{2}$ offsets of new sources, modified sources, or sources of certain vintages, or (2) carbon taxes. The proposed offset systems allowed for interutility trading, similar to Title IV, although allowances could only be created by $\mathrm{CO}_{2}$ emission reductions from current $\mathrm{CO}_{2}$ emission levels.

The implications of the proposed bills to regulated GHGs and the eventual result of the NES least-cost energy strategy (Section 1602) on utility compliance planning and growth are uncertain. The institution of carbon taxes or increased efficiency standards on existing coal-fired power plants would certainly raise energy costs and be problematic for controls established for other pollutants (i.e., scrubbers for $\mathrm{SO}_{2}$ and overfire air for $\mathrm{NO}_{\mathrm{x}}$ ). The offsets system would alter new capacity choice and tend to encourage more lower and no-emission technologies (e.g., nuclear, renewable, natural gas, and conservation). The use of incentives for DSM and renewable technologies should encourage greater use of these technologies, although the effectiveness of these efforts in significantly reducing or stabilizing $\mathrm{CO}_{2}$ emissions is uncertain, given predicted adoption rates.

\subsubsection{Summary}

The acid rain compliance option chosen by a utility will alter emissions of other pollutants. We have considered the environmental regulations with particular importance to utility $\mathrm{SO}_{2}$ compliance options to be Title IV NO controls; Title I $\mathrm{PM}_{10}, \mathrm{SO}_{2}, \mathrm{NO}_{2}$, and $\mathrm{O}_{3}$ controls (for both nonattainment and attainment areas); Title III HAP controls; potential controls of $\mathrm{CO}_{2}$; and potential increased regulation of aqueous and solid waste produced by the combustion process. Potentially, all of these emissions will be affected by the choice of control technologies for $\mathrm{SO}_{2}$ (although $\mathrm{NO}_{\mathrm{x}}$ emissions will tend to be affected to a lesser extent). These considerations will certainly affect compliance costs and fossil-fuel plant operations. Conversely, control requirements imposed by other environmental regulation will influence utility compliance choice, altering $\mathrm{SO}_{2}$ and possibly $\mathrm{NO}_{\mathrm{x}}$ emissions. 


\section{PUBLIC UTILITY REGULATION UNDER TITLE IV}

Theoretically, emission allowance systems are superior to other market and command-and-control systems for emission control (Tietenberg 1985). The issuance of a fixed quantity of allowances caps total emissions, as opposed to emission taxes or standards that do not limit aggregate emissions to a desired level at the start of a program. Therefore, an emission target may be more easily achieved. Those firms with higher control costs will acquire allowances from firms with lower control costs, thereby avoiding the requirement to install expensive controls. The value of reducing emissions (in the form of freed allowances for sale) creates an incentive for innovative methods to control emissions; however, with tariff (rate) regulations, the incentive to choose compliance options that minimize compliance choice may be distorted.

Related to compliance with multiple environmental regulations is the issue of rate regulation and the influence on $\mathrm{SO}_{2}$ compliance. Together, these factors will shape how utilities choose to comply with $\mathrm{SO}_{2}$ requirements and will influence the ability of utilities to comply with many of the uncertain, future environmental regulations. This section provides a brief overview of rate regulation, the impact of allowance trading in a regulated industry, potential methods of overcoming distortional compliance choices created by rate regulation, and an illustration of utility compliance behavior.

\subsection{UTILITY RATE REGULATION AND DISTORTIONAL PRESSURES}

Electric utilities are arguably one of the most regulated industries. ${ }^{84}$ Rate regulation is designed to allow a utility an equitable rate of return on its capital expenditures and compensation for operating expenditures. ${ }^{85}$ In the rate-making process, the PUC decides an allowable rate of return on the utility's capital expenditures and compensation for operating

84 Excluding rate and entry regulation administered by state PUCs, public utilities are also subject to regulation by the Securities and Exchange Commission (SEC) and the Federal Energy Regulatory Commission (FERC). Public utility financial dealings may be subject to SEC review if the utility is part of a holding company. Wholesale pricing of electric power is subject to the regulatory review of FERC. In addition to FERC power transfer and pricing regulations, utility power transfers and operations are subject to review by quasi-autonomous private regulatory organizations such as regional reliability councils. Possibly the only more regulated industries would be banking and securities exchanges.

85 Rate-of-return or cost-plus regulation tends to be the norm; however, competitive pressures and recognition that rate-of-return regulation encourages inefficient behavior have led to expanded use of incentive regulation and market-driven forces to determine the prices of electricity, delivered natural gas, and telecommunications and returns to shareholders. 
expenditures. ${ }^{86}$ Rates would then be determined on the basis of meeting the utility's total revenue requirements (TRRs). The TRR is equal to

$$
T R R=(R B-d) \times R O R+F U E L-O S S+O \& M+D+O
$$

where

$$
\begin{aligned}
\mathrm{RB} & =\text { rate base capital, } \\
\mathrm{d} & =\text { cumulative depreciation, } \\
\mathrm{ROR} & =\text { rate of return on capital, } \\
\text { FUEL } & =\text { annual fuel cost expense, } \\
\text { OSS } & =\text { annual power exports off-system - power imports from off-system, } \\
\text { O\&M } & =\text { annual operations-and-maintenance expense, } \\
\mathrm{D} & =\text { annual depreciation expense, and } \\
\mathrm{O} & =\text { other expenses, including taxes. }
\end{aligned}
$$

Rate-of-return regulation passes through operating costs directly to ratepayers, while capital or rate-base expenditures are allowed some rate of return on capital. Assuming that the objective of a public utility is to maximize shareholder returns, those actions that increase the capital stock are preferred over those actions that increase operating expenditures. The effect of increasing capital levels beyond the socially efficient level is known as the Averch-Johnson (A-J) effect (Averch and Johnson 1962).

The incentive for an increase in investment and output may induce public utility companies to make investments where marginal social benefits are less than the marginal social costs (ceteris paribus). Inefficient resource acquisition will occur if the marginal private benefits of an action are greater than the marginal social costs. As indicated by Kahn (1988), the A-J effect may be reflected in the following:

- Resistance to marginal cost pricing (which may reduce demand and reduce justification for expansion),

- Construction and maintenance of large levels of excess capacity,

- Rejection of extensive power pooling and power purchases (as no returns to capital are gained on these transactions),

${ }^{86}$ For an examination of the issues involved in determining rate base, rate of return, operations expenditures, and similar rate-making issues, see Kahn (1988). 
- Resistance to capital saving technology,

- Adherence to "excessively" high standards of reliability (as reliability tends to involve capital expenditures), and

- Tendency to price rates below marginal cost, especially in competitive situations (using regulated markets to cross-subsidize competitive markets). ${ }^{87,88}$

The A-J effect indicates that a firm subject to price regulation has an incentive to acquire capital (or engage in other nonsocially productive activities, see previous discussion) beyond its socially productive level. The production efficiency condition for the firm is distorted so that

$$
-\frac{\delta k}{\delta l}<\frac{p}{r}
$$

where

$$
\begin{aligned}
& l=\text { amount of variable input, } \\
& k=\text { amount of capital, } \\
& p=\text { price of variable input, and } \\
& r=\text { price of capital input. }
\end{aligned}
$$

While the relative weight and influence of the A-J effect may be debatable, rate regulation does have powerful impacts on utility planning and operations. Public utility commission action and treatment regarding what can be included in rate base, expected returns on capital expenditures, regulatory lag, depreciation allowed on alternative capital expenditures, fuel adjustment clauses, DSM activities, power purchase agreements, and

${ }^{87}$ Note that there have been several challenges and explanations regarding the validity of the A-J effect in the "real world." Factors such as regulatory lag regarding the speed to recoup capital expenditures, PUC "used-and-useful" and prudence review of excessive expenditures, greater competitive pressures, and increasing costs of acquiring greater levels of financial capital will reduce the incentive for inefficient behavior (Kahn 1988). Under uncertainty, Baron and Taggart (1977) have found that there may be a negative A-J effect that discourages inefficient levels of capitalization and overexpenditure.

88 In fact, there is evidence that the rate of return of utility capital expenditures is below the market rate of return, leading to avoidance of capital expenditures. Beginning in the 1970s, a series of energy price increases, combined with higher inflation, labor disputes, and greater environmental and safety regulation, led to greater utility fuel and capital costs. The increase in energy and electricity costs led to a dramatic decrease in the growth of electricity demand. During this period, numerous units came on-line that tended to have delays and high costs associated with them. The combination of more expensive capital and declining demand growth has led to plants being ruled partially not "used-and-useful" and some capital costs not being considered prudent. 
treatment of operating expenditures will alter utility acquisition of the various resources required to provide electricity services. Distortions created by regulatory treatment of these options away from their economic or market-determined level will result in uneconomic levels of these resources being acquired (i.e., the production efficiency condition will not hold). ${ }^{89}$ Uncertainty (and risk) regarding the regulatory treatment of electric services will also cause uneconomic impact on utility behavior. Greater uncertainty (and risk) regarding the treatment of particular compliance strategies will tend to move the utility away from the adoption of those options (McDermo، et al. 1993). ${ }^{90}$

Utility investments in pollution control or allowance purchases will be influenced by the treatment of these factors in the rate structure and the uncertainty (and risk) regarding the treatment of these factors. Of particular importance will be the rate treatment and flexibility permitted for $\mathrm{SO}_{2}$ allowance trading. Regulatory policies leading to the distortion of allowance values (away from a market-determined price) cause greater uncertainty and less trading than optimal. In other words, compliance behavior will be distorted away from optimal levels, and higher compliance costs in the aggregate will result. Section 2.2 reviews recent suggestions for regulatory treatment of $\mathrm{SO}_{2}$ compliance options and allowances.

\subsection{REGULATORY TREATMENT OF $\mathrm{SO}_{2}$ COMPLIANCE OPTIONS}

As indicated previously, traditional rate-making practices (i.e., rate-of-return regulation), along with other regulatory distortions from market "norms," may provide utilities an incentive to choose nonoptimal compliance strategies (from a societal perspective). A key factor to ensure effective operation of the $\mathrm{SO}_{2}$ allowance program will be the regulatory treatment of allowances and compliance options. In addition, factors such as the formation of institutional markets for allowance trading (e.g., brokers, central clearinghouses, and exchanges) that reduce transaction costs and bear risk will be important to achieve the promised cost savings. ${ }^{91}$ Several studies have reviewed the issue of rate treatment of allowances and compliance costs to encourage nondistortional, symmetrical treatment of

${ }^{89}$ In essence, the production efficiency condition will not hold or

$$
\frac{\delta \mathrm{k}}{\delta \mathrm{l}} \neq \frac{P_{l}}{P_{k}}
$$

where $k$ and $l$ indicate input quantities, and $P_{i}$ indicates the price of that commodity.

90 For an examination of risk and uncertainty's effect on the adoption of new generation technology, see McDermott et al. (1993). Regulatory risk and uncertainty play an important role in utility generation choices. The general result is the avoidance of new, innovative technologies due to both technology risks and regulatory risks.

91 Annual savings of $\$ 2$ billion to $\$ 5$ billion have been estimated by a variety of sources. See, for example, van Horn and Hewson (1993) and Molburg et al. (1991). 
compliance activities in the interest of promoting a market that generates the predicted cost savings. 92

Studies by Hahn and Noll (1983), Bohi and Burtraw (1991; 1992), and Rose et al. (1992) indicate that traditional methods of rate-making will distort cost-effective utility compliance behavior. Rose et al. (1992) summarize the regulatory factors that may distort utility compliance behavior. These factors are as follows:

- Rate treatment and accounting of allocated, purchased, and sold allowances;

- Distortions created by rate-basing or preferential treatment of certain options, such as scrubbers, while other options are passed through to rates (e.g., fuel switching); and

- Uncertainty created by after-the-fact prudence reviews (i.e., Monday morning quarterbacking of decisions) and distorted signals sent by past and current PUC behavior.

Hahn and Noll (1983), Bohi and Burtraw (1992), and Rose et al. (1992) provide economic models of regulated agents (in the case of Hahn and Noll) and public utilities (in the cases of Bohi and Burtraw and Rose et al.). Through these models, agent behavior and possible solutions to encourage efficient behavior are addressed. The models of Bohi and Burtraw (1992) and Rose et al. (1992) are similar in their implications for optimal regulatory policy. The Bohi and Burtraw (1992) model of utility behavior, along with the implications of the regulatory induced distortions, is illustrated subsequently.

Bohi and Burtraw (1992) pose the objective of the public utility as maximizing the expected share price for current stockholders as

$$
\Omega=E\left[\Sigma_{t=1}^{T} \delta^{t} \varepsilon_{t}\right]
$$

where

$$
\begin{aligned}
& \varepsilon=(1-\tau)\left(\Pi_{t}-\text { depreciation }_{t}\right)+\text { depreciation }_{t} \\
& \tau=\text { corporate income tax rate } \\
& \Pi=\text { revenues }_{t}-\text { costs }_{t}
\end{aligned}
$$

92 Note that symmetrical treatment of all opportunities (implying that only market forces are reflected in utility compliance choices) may not be the goal of all states. Due to local impacts of $\mathrm{SO}_{2}$ deposition or impacts on local and regional use (i.e., high-sulfur coal), states or PUCs may design policies that reduce negative impacts on the environment and local economies. Note that states may promote certain compliance options to avoid the local and regional impacts of other pollutants (Bailey et al. 1993). 


$$
\begin{aligned}
& \mathbf{E}=\text { expectations operator, } \\
& \mathbf{\Omega}=\text { expected market value of the firm, and } \\
& \delta=\text { discount rate. }
\end{aligned}
$$

Maximizing the value of the firm under rate regulation and a system of marketable allowances leads to the optimality condition:

$$
\frac{\mathrm{dA}}{\mathrm{dZ}}=-\frac{c \beta}{p \alpha}
$$

where

$$
\begin{aligned}
& A=\text { quantity of allowances (or other compliance option), } \\
& Z=\text { quantity of other pollution control input, } \\
& c=\text { price of other pollution control input, } \\
& p=\text { price of allowances (or other compliance option), } \\
& \alpha=\text { cost recovery rules applied to } \mathrm{A}, \text { and } \\
& \beta=\text { cost recovery rules applied to } \mathrm{Z} \text {. }
\end{aligned}
$$

In the absence of rate regulation, the product of $\beta$ and the inverse of $\alpha$ would be unitary. In others words, the ratio of the prices of the compliance inputs would be equal to the marginal rate of technical substitution (MRTS) between the inputs. The social optimum would be achieved (the minimized cost of compliance across all affected firms) at the point where MRTS $_{i}=$ MRTS $_{j}$ for all $i, j=1, \ldots, N$; however, under rate regulation, $\alpha$ and $\beta$ may not be unitary (the deviation of regulated returns from the market) and may differ for each firm (due to alternative PUC treatment of each firm). ${ }^{93}$

Utility compliance activity will be influenced by the relative treatment of the compliance assets or whether $\alpha$ and $\beta$ are positive, negative, or differ in value. If both compliance options have positive net rates of return (implying regulatory returns greater than the market return on the same assets), the A-J effect will occur. The asset with the relatively greater return will be acquired in greater quantities. If the net rate of return on both options is negative, the firm will minimize investments in those activities. The option that generates the greater negative returns will have less investment relative to the option with lower negative returns. It follows that if one option has a positive net rate of return and

93 Uniform standards of accounting for certain factors will tend to make treatment equal across states; however, PUCs have engaged in a wide variety of treatment for many regulatory factors, as has FERC. Even within states, utilities may find differences in rate treatments due to special conditions, such as cooperation with the regulator, past behavior, and state goals. 
the other a negative rate of return, the option with the positive net rate of return will receive greater investment.

Bohi and Burtraw (1992) pose a solution to the rate-making dilemma through examination of utility behavior under two alternative states-of-the-world. In the first state-of-the-world, the net rate of return of all compliance options is negative. An example of this situation is prudence review of utility capital expenditures so part or all of the plant is not allowed into the rate base but all fuel expenditures are allowed into rates but receive no ret $\mathrm{n}$. The firm has an incentive to engage in fuel-switching activities that earn no gain or small losses, rather than capital expenditures that earn negative returns. In this state-of-the-world, the PUC should develop symmetrical treatment of all compliance options to ensure the optimal level of compliance activities.

In the second state-of-the-world, one or more compliance activities earn positive net rates of return, implying returns for some activities are greater than the market return on those activities. This situation is very similar to the A-J effect. The utility will choose the compliance method from which it receives the highest net rate of return; for instance, if fuel expenditures receive simple pass-though, while FGD technologies receive positive net rate of return from being included in rate base and allowed construction work-in-progress (CWIP), the FGD will be chosen as the compliance option, all other things being equal. Bohi and Burtraw (1992) indicate the regulatory solution to encourage efficient compliance option choice in this case is to designate that options with lower net rates of return receive preferential treatment (in terms of rate-base return, depreciation, adjustment clauses, etc.).

Perhaps the most important regulatory issue will be the treatment of allocated, purchased, and sold allowances. The general consensus is that allocated allowances will be treated as a zero cost. Bohi and Burtraw (1992) recommend the following treatment of allowances:

- Allowance costs should be allocated to the rate base and valued at original cost;

- Revenues from allowance sales should first be applied to offset the value of allowances already in the rate base by using a last-in first-out (LIFO) accounting methodology;

- Revenues generated from allowance sales should next be applied to offsetting the costs of the control technology that freed allowances for sale; and

- Remaining revenues should be treated as a capital gain to be divided in some manner between ratepayers and shareholders.

Rose et al. (1992) point to the fiduciary duty of a utility to provide service at the lowest reasonable cost. This implies that benefits from the sale of the initially allocated allowances should flow to consumers in an effort to reduce the cost of compliance. To 
encourage trading, Rose et al. (1992) suggest that proportional ownership of the allocated allowances be attributed to each unit on the utility system, so if these allowances are sold, the benefits of the sale flow in proportion to the ownership of the allowance (i.e., shareholders or ratepayers). The proportion, as indicated by Rose et al. (1992), could be based on the level of plant depreciation, where a fully depreciated plant's allowances would be owned entirely by the ratepayers. Rose et al. (1992) also offer a mechanism through which the public utility could "purchase" the allocated allowances from ratepayers. The purchase of an allowance would reduce costs to ratepayers (the value of the allowance would be compensated to ratepayers through a reduction in rates); the utility could then sell the allowance or use it for some other purpose, so all of the benefits would flow to the ratepayers.

Rate treatment of compliance options and allowances will affect compliance choice. In addition, the perceived uncertainty regarding regulatory treatment of options will alter compliance choices, perhaps inefficiently. As indicated previously, distortion of allowed returns from market returns and distortion of depreciation from economic depreciation will lead to an inefficient level of compliance resources being chosen. The problem of inefficient compliance choice due to regulation is further exacerbated when future regulatory treatment is not defined or is uncertain. Several solutions to encourage efficient levels of compliance and reduce regulatory induced uncertainty have been proposed.

Rose et al. (1992) suggest that symmetrical treatment of compliance options is required in order to ensure least-cost compliance behavior. Taylor (1992) indicates that the relative rate and price impacts of compliance should be considered in utility compliance choices; for instance, allowance prices are expected to increase over time as the allocated allowances are ratcheted down in 2000 and as new baseload growth is needed. At the same time, the capital-intensive compliance options' impact on the rate base decreases over time. If examined on a levelized cost basis, capital-intensive options may have higher costs than less capital-intensive and allowance options. Weighing compliance choice based on levelized cost may not be the proper decision. Instead, the net difference of the price paths of the two options should be examined to determine the optimum compliance option. Because of the gains from the capital-intensive project in later years, the higher up-front cost is compensated. Regulators should take into account the potential price path of alternative compliance strategies in their review of utility compliance planning.

As indicated by Bohi and Burtraw (1992), regulatory treatment of the compliance options should be based on the negative or positive net rates of returı of the compliance options, which may make the capital-intensive policy or program optimal. If both assets have negative net rates of return, the options should be treated symmetrically; however, if one or more of the options receive positive net rates of return, symmetry of treatment will be ineffective because the utility will tend toward the option with the highest cost. Given that capital investments (if they receive a positive net rate of return) tend to have higher expenses, policies should be designed to increase the rate of return on, for example, allowances (Bohi and Burtraw 1992). 
An intriguing idea for avoiding the bias created by traditional, cost-plus regulation is the use of incentive regulation. PSI Energy has submitted an incentive regulation for $\mathrm{SO}_{2}$ compliance with the Indiana PUC. A baseline cost of compliance for the PSI system was estimated. Around this baseline compliance cost, a dead band was established. If the utility manages to reduce compliance costs $20 \%$ below the baseline, the savings are to be equally divided between shareholders and ratepayers. Through the use of this mechanism, the utility is encouraged not to choose high-cost options to maximize shareholder returns but, instead, to choose the least-cost options to maximize ratepayer returns.

An issue linking prudence review, allowance price uncertainty, and compliance planning is formation of the allowance market. To capitalize on the gains available from allowance trading, certain factors need to be present in the market, such as stability, liquidity, and market institutions (South et al. 1992a). The presence of these factors will reduce price uncertainty and transaction/search costs, resulting in greater cost savings. Uncertainty regarding the future price of allowances, other abatement inputs, and prudence review also biases compliance choice. In cases where regulatory treatment of abatement options is uncertain and the allowance market is relatively thin, utilities may internalize allowance trading and avoid entering the allowance market.

Several methods have been proposed and implemented on the state level to reduce this uncertainty. The first method is preapproval of compliance plans. The utility is allowed to submit its plan for approval to the PUC before any compliance actions are taken. The PUC would then approve or reject the plan. If approved, the plan would not be subject to prudence-of-plan review, but the expenditures are still subject to prudence review. Another action that could be taken by the PUCs is to indicate the treatment of all relevant compliance options and the trading prices up front. Under some oversight, allowance trades made by the utility could be considered prudent and reasonable.

To a certain extent, cost-inflating, nonoptimal compliance decisions will be reduced because of growing competitive pressures in the wholesale and retail electricity markets. A utility may place itself at a disadvantage in the wholesale market by choosing those compliance options or strategies that have preferential rate treatment but create higher prices in the wholesale electricity market. Higher rates may make industrial cogeneration projects economic or encourage municipalities to seek power from other utilities, requiring the high-cost utility to wheel power to the municipality. The result for a utility and ratepayers is lower revenues and higher rates. The loss of customers in this manner and resulting rate increases would most likely lead to unfavorable prudence review by the PUC. Independent power may also find entry easier into the utility system as avoided energy costs would rise. 


\subsection{UTILITY COMPLIANCE BEHAVIOR AND PORTFOLIO CHOICE}

Prior to the 1990 CAAA, utility compliance decisions were based on state-determined emission limits or, if the unit was a new source, on NSPSs for the boiler. ${ }^{94}$ Allowance trading has the ability to greatly alter utility compliance strategies. Instead of control restrictions based on a mandated standard, utilities may use a portfolio approach to compliance to achieve least-cost levels of emission control. ${ }^{95}$ Portfolio compliance choice is defined as the $\mathrm{SO}_{2}$ compliance choice set for a utility such that various control levels and options are determined for all units in a system, while minimizing total compliance costs. In an unrestricted allowance market, portfolio compliance choice will result in an equalization of marginal costs of control (MCC) across units so that

$$
\mathrm{MCC}_{1}=\mathrm{MCC}_{2}=\ldots=\mathrm{MCC}_{\mathrm{n}}=\mathrm{P}_{\mathrm{a}}
$$

where

$$
\begin{aligned}
& \mathbf{n}=1, \ldots, \mathrm{k} \text { units, and } \\
& \mathbf{P}_{\mathbf{a}}=\text { market allowance price. }
\end{aligned}
$$

Systemwide cost minimization results in some units overcontrolling, undercontrolling, or exactly controlling emissions levels relative to their allocated allowances; for example, assume that a three-unit system has the following marginal cost of controlling $\mathrm{SO}_{2}$ emissions. $^{96}$ (See Figures 2.1, 2.2, and 2.3.) Each unit receives an initial allowance allocation of 50,000 . If the allowance price is $\$ 400$, unit 1 will use FGD to control 70,000 tons, unit 2 will use fuel switching to control 58,500 tons, and unit 3 will use fuel switching to control 47,800 tons of $\mathrm{SO}_{2}$. Unit 1 overcontrols, while units 2 and 3 undercontrol. Unit 1 could use the excess allowances to offset the excess emissions of units 2 and 3 and have allowances available for banking or selling.

Another way of portraying system compliance activities is through a systemwide marginal control cost curve, as illustrated in Figure 2.4. Assuming an allowance price of $\$ 400 /$ ton, the optimal strategy for the system is to fuel-switch units 1 and 3 to low-sulfur coal and cofire coal with natural gas in unit 2. Figure 2.4 illustrates actual "lumpiness" of compliance options.

94 The bubble program for criteria air pollutants does allow a form of emissions averaging for multiple units at a particular plant; however, the implementation of these bubbles in the electricity generating sector is not extensive.

95 Compliance choice flexibility is allowed to the extent that the alteration of $\mathrm{SO}_{2}$ emissions does not lead to the unit violating local ambient air quality standards for $\mathrm{SO}_{2}$ (and other pollutants).

${ }^{96}$ For simplicity, the control options are assumed to be FGD or fuel switching to compliance coal. Actual costs are not represented here - this is only a hypothetical representation. 


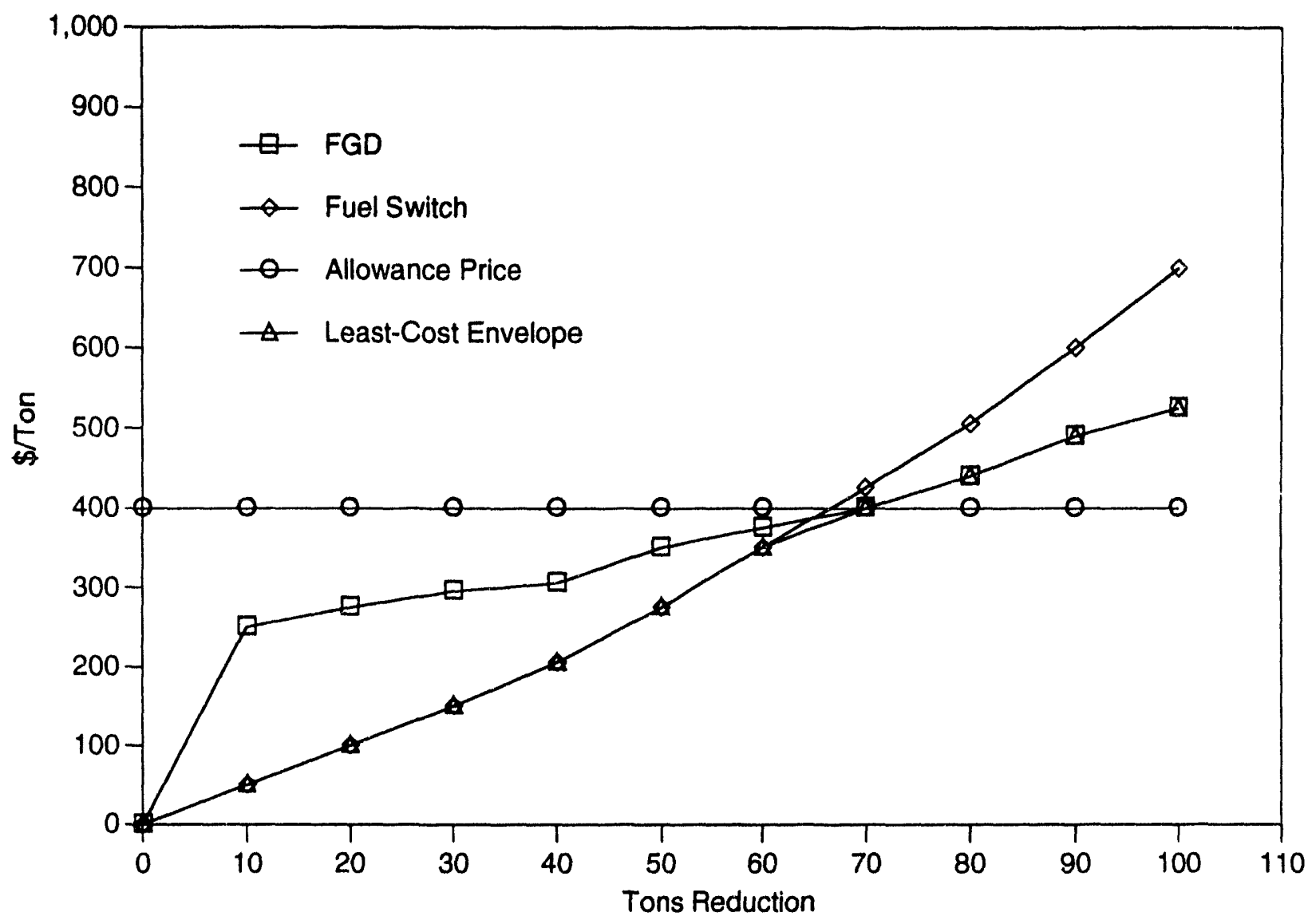

FIGURE 2.1 Marginal Cost of Control: Unit 1

In practice, actual determination of the least-cost compliance strategy will be fraught with regulatory, technology, and price uncertainties that may distort choice away from the least-cost strategy. A key variable affecting the choice of $\mathrm{SO}_{2}$ compliance options is uncertainty. Integrated resource planning (IRP) and compliance planning can be complementary for purposes of minimizing energy costs while maintaining a chosen level of reliability under uncertainty. ${ }^{97,98}$

97 See Hirst and Schweitzer (1989) for an examination of the role of uncertainty in electric utility resource plans. The central result of resource (and compliance) choice under uncertainty is choosing the plan that is among the low-cost/high-value options and is relatively robust under several alternative price scenarios; for example, a strategy's provision of low-cost, reliable energy services is not greatly affected by alterations in relative fuel costs, technology costs, etc. Strategies that vary greatly in costs and reliability tend to be less beneficial.

98 The compliance plan and the integrated resource plan (IRP) attempt to minimize the cost of delivered fuel while maintaining a given level of reliability. Both plans rely on energy and price forecasts for the development of strategies and scenarios. Similar to the resource plan, the compliance plan examines altering dispatch, purchasing power, and use of DSM. The central difference between the two plans is the inclusion of emissions allowance prices within the compliance plan. While the compliance plan tends to have a shorter forecasting range (5-15 years seems to be the norm), IRPs can extend up to 30 years. 


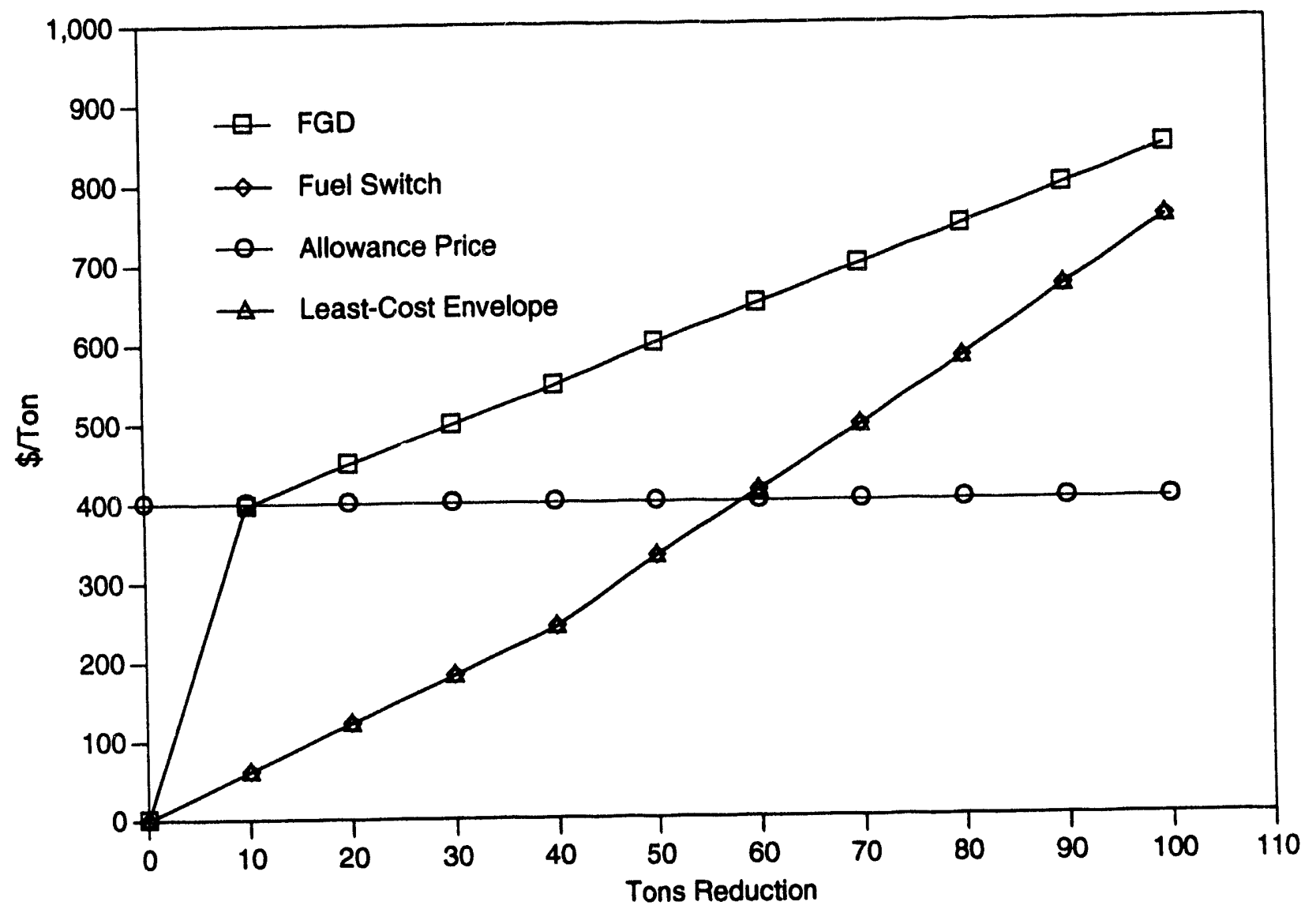

FIGURE 2.2 Marginal Cost of Control: Unit 2

Apart from regulatory considerations (which will affect the relative prices of most of the compliance options), the major compliance planning uncertainty is $\mathrm{SO}_{2}$ allowance prices. Predictions of 1995 allowance prices have varied from $\$ 600$ per allowance in 1990 to approximately $\$ 500$ in mid-1991 and finally to between $\$ 200$ and $\$ 400$ per allowance by mid-1992. The price of allowances will nıake the difference among scrubbing, fuel switching, purchasing allowances, and other compliance options. White (1991) assembled a list of 40 factors affecting allowance prices. Eliminating regulatory issues and expanding the list further would include fuel prices (natural gas, oil, and low-sulfur and high-sulfur coal), capital costs (FGD, boiler refit, and greenfield), long-run financing costs, industrial opt-ins, price of purchased power (utility and nonutility), development of futures/options markets, availability of allowances/market function, clean coal technology penetration, innovative technology reliability, demand growth, seasonal weather fluctuations, fuel availability (pipeline constraints), technology availability, and labor costs. Furthermore, fuel prices and control technology price are a function of allowance prices, making compliance choices dynamic and even more uncertain. 


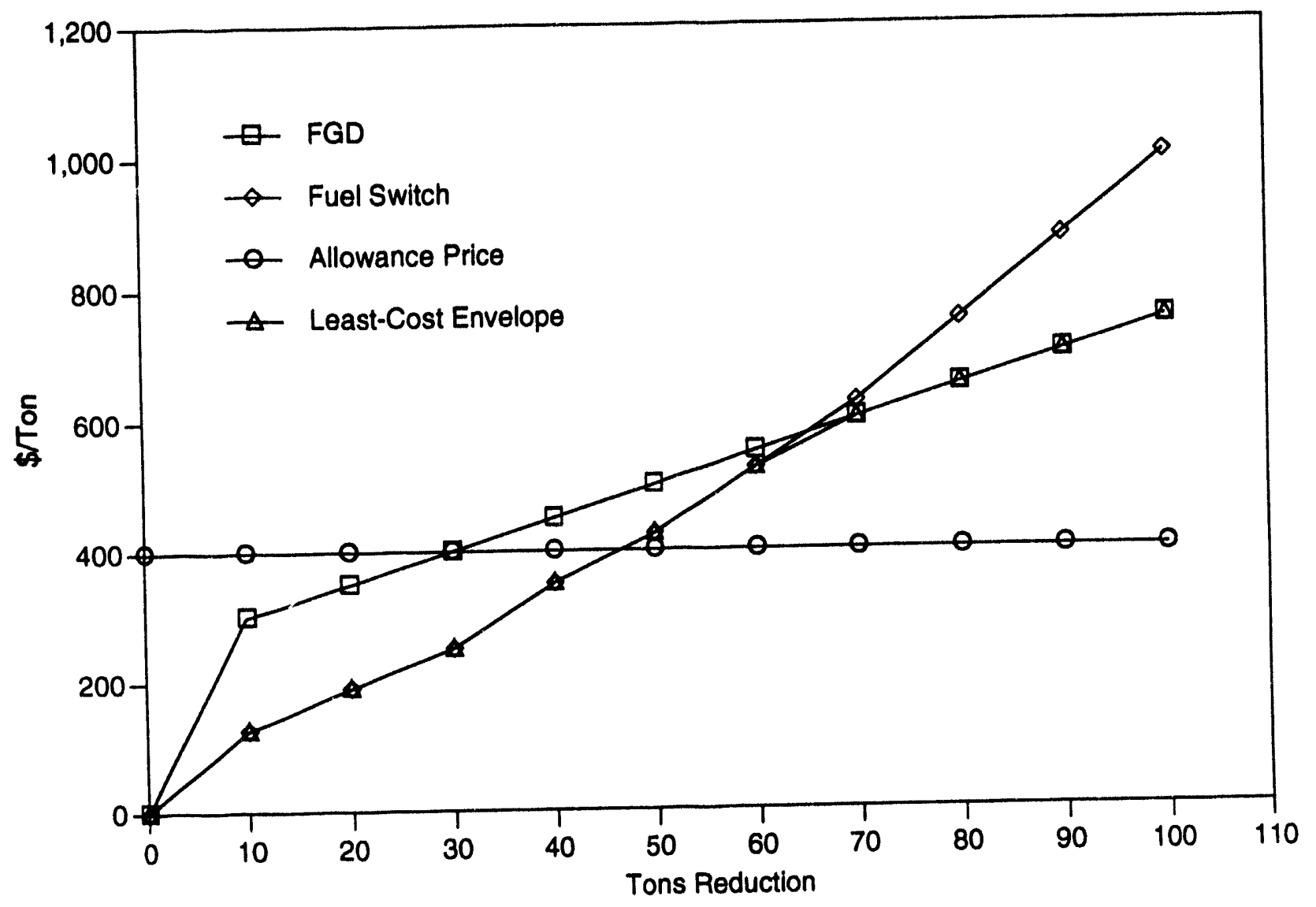

FGURE 2.3 Marginal Cost of Control: Unit 3

Portfolio compliance can be used to mitigate these risks. Through exchanges of power (through sale/purchase and altered dispatch order) and intra- and interfirm allowance exchanges, firms can hedge against a variety of uncertainties. In addition, the use of of key variables are revealed (or at least until some of the uncertainty has been reduced). 


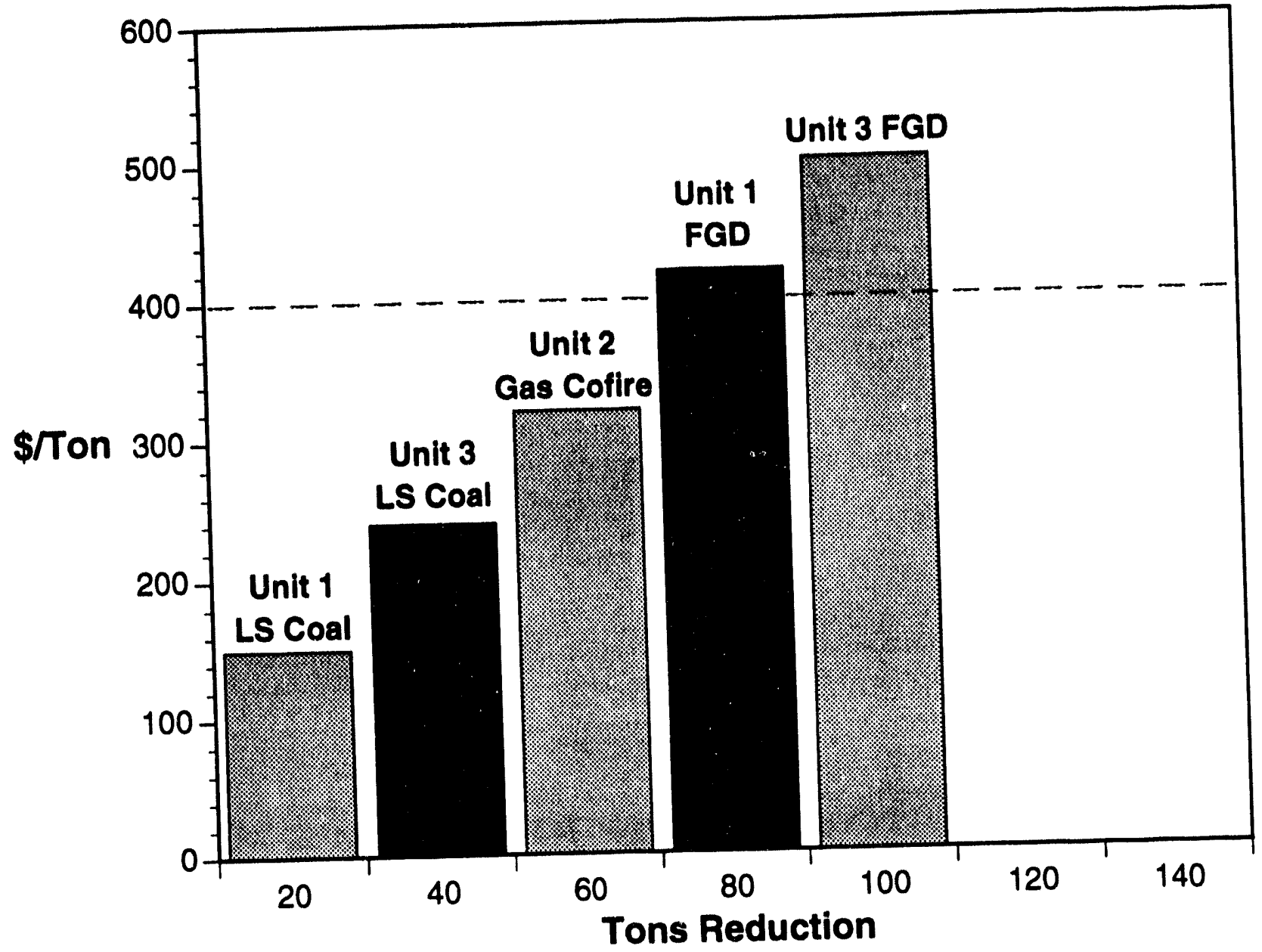

FIGURE 2.4 Utility Compliance Option Supply Curve (LS, low sulfur) 


\section{ISSUES OF SYNERGISTIC POLLUTION CONTROL AND COPOLLUTANTS ASSOCLATED WITH UTILITY $\mathrm{SO}_{2}$ COMPLIANCE OPTIONS}

The purpose of this section is to discuss the decisions utilities will face in complying with environmental regulations. While the Title $\mathrm{IV} \mathrm{SO}_{2}$ requirements may be the primary concern of utilities at the present time, they are by no means the only ones that must (should) be considered. Careful consideration of interactions and effects of utility compliance actions must be made in order to minimize compliance costs while meeting regulatory requirements.

\subsection{FRAMEWORK AND DESCRIPTION OF BASE UTILITY UNIT FOR EXAMINING SYNERGIES AND COPOLLUTANTS}

There are hundreds of power generating units in existence, with a wide variety of configurations and designs. For illustrative purposes, the configuration shown in Table 3.1 was selected as a representative unit. This coal-fired unit is affected by Phase I regulations.

The utility owning this unit will have to control $\mathrm{SO}_{2}$ emissions at a rate approximately $34 \%$ beyond its baseline to comply with Phase I regulations; it would receive Phase I allocations of approximately 17,230 tons. For Phase II, the values would be $68 \%$ and 8,271 tons.

The objective in choosing a "representative" unit was to provide a basis for discussion. This entailed defining a unit with characteristics typical of an actual Phase I affected unit. Of the 263 generating units that have been assigned Phase I allowances, nearly three-fourths of them range between 100 and $500 \mathrm{MW}$ in capacity (Taxon et al. 1993). The 250-MW unit size was chosen as representative; the characteristics of the coal shown are consistent with common coal sources available.

Several sources report that existing utility generating units typically utilize electrostatic precipitators (ESPs) as the particulate control technique of choice. These units do not have $\mathrm{SO}_{2}$ control equipment installed. They will face decisions regarding the optimization of their control strategy while considering both phases of the Title IV $\mathrm{SO}_{2}$ regulations and interactions with (or impacts of) the other environmental regulations listed previously. In addition, state and local regulations and policies may also be applicable. 
TABLE 3.1 Configuration of Typical or Reference Plant

\begin{tabular}{ll}
\multicolumn{1}{c}{ Specification } & \multicolumn{1}{c}{ Data } \\
\hline Generating capacity & $250 \mathrm{MW}$ \\
On-line factor & $65 \%$ \\
Coal use & $98 \mathrm{tons} / \mathrm{h}$ \\
Coal characteristics & \\
$\quad$ Heating value & $12,360 \mathrm{Btu} / \mathrm{hb}$ \\
Sulfur content & $2.5 \%$ \\
Heat rate & $9.69 \mathrm{mmBtu} / \mathrm{MW}-\mathrm{h}$ \\
Annual $\mathrm{SO}_{2}$ emissions & $26,192 \mathrm{tons}$ \\
Annual NO $\mathrm{N}_{2}$ emissions & 415 tons \\
Annual NO emissions & $5,125 \mathrm{tons}$ \\
Annual Hg emissions & 0.2 ton \\
Annual HCl emissions & 558 tons \\
Fly ash & $11.4 \mathrm{tons} / \mathrm{h}$ \\
Furnace bottom ash & 3.2 tons $/ \mathrm{h}$ \\
Economizer ash & 1.2 tons $/ \mathrm{h}$ \\
Gases entering ESP & \\
Total (standard) & $546,000 \mathrm{cfm}$ \\
Total (actual) & $802,000 \mathrm{cfm}$ \\
$\mathrm{SO}_{2}$ & 4.6 tons $/ \mathrm{h}$ \\
$\mathrm{SO}_{3}$ & 0.062 ton $/ \mathrm{h}$ \\
$\mathrm{NO}_{2}$ & 415 tons $/ \mathrm{h}$ \\
$\mathrm{NO}^{\mathrm{HCl}}$ & 0.9 ton $/ \mathrm{h}$ \\
\hline
\end{tabular}

a Many of the specifications listed for this typical or reference plant were provided by the DOE's Pittsburgh Energy Technology Center.

\subsection{UTILITY $\mathrm{SO}_{2}$ COMPLIANCE METHODS AND ASSOCIATED POLLUTANTS AND COSTS}

\subsubsection{Current Utility Phase I and Phase II Compliance Decisions}

Table 3.2 presents an overview of utility Phase I compliance strategies as of September $30 .^{99}$ The predominant utility strategy is fuel switching to lower sulfur coal. In many cases, some level of continued use of high-sulfur coals will occur for several years in the units that have indicated fuel switching. An estimated 26 units are in the process of

${ }^{99}$ See Bailey et al. (1993) for further details. 
TABLE 3.2 Summary of Compliance Options for Phase I Affected Units

\begin{tabular}{lrr}
\hline \multicolumn{1}{c}{ Compliance Option } & $\begin{array}{r}\text { Number } \\
\text { of Units }\end{array}$ & $\begin{array}{c}\text { Capacity } \\
\text { (MW) }\end{array}$ \\
\hline Coal blend & 20 & 3,871 \\
Coal switch & 102 & 42,055 \\
Natural gas & 2 & 441 \\
Wet FGD & 26 & 13,189 \\
Boiler repower & 1 & 85 \\
Substituting/compensating unit & 89 & 27,464 \\
Sulfur-free reduced utilization & 56 & 18,348 \\
Allowance purchase & 8 & 3,521 \\
Allowance offsets & 32 & 10,267 \\
Existing compliance & 28 & 8,933 \\
Unidentified/no plan indicated & 11 & 2,733 \\
Retire & 6 & 0 \\
\hline
\end{tabular}

installing these systems. System-level emission strategies are also prominent. Reduced utilization, substitution units, conservation and load management, and allowance offsets account for over 100 units.

\subsubsection{Selection and Justification of Technologies Chosen for Examination}

In complying with $\mathrm{SO}_{2}$ control requirements, a variety of options are available to utilities. The options fall into four general categories: (1) fuel preparation measures, (2) flue gas treatment, (3) burner/combustion modifications, and (4) reduction of generation. For purposes of this discussion, we assume that utilities will want to maintain generating capacity, and, thus, reduction of generation will normally not be chosen as a compliance strategy. The compliance strategies examined include the following:

- Fuel-related strategies

- Fuel blending

- Fuel switching

- Gas cofiring

- Coal cleaning

- Flue gas treatment

- Wet lime/limestone

- Wet regenerable 
- Spray dryer

- Sorbent injection

- Boiler repowering

Research and testing of $\mathrm{SO}_{2}$ control technologies have made tremendous progress in the last decade. There are now many variations of control strategy that provide enhancements in specific situations and many others that may be breakthroughs in technology (see South et al. 1990); however, few of these are proven through utility field use or are commercially available. Electric utilities tend to be a conservative group and can be expected to utilize proven methods and methods they know, rather than experiment with new technology, unless there are strong incentives to do so. Reasons for risking use of less-proven methods are usually economic forces or unusual situations affecting individual units or plants. Our typical plant likely will not be subjected to such risk-promoting factors.

\subsubsection{Examination of Selected Compliance Options Based on Cost, Pollutants, Flexibility, and Ability to Implement}

The following paragraphs present brief discussions of the selected conapliance options, along with their advantages and disadvantages. A summary of issues and important considerations related to the employment of these compliance options is presented in Tables 3.3 through 3.11 .

\subsubsection{Fuel-Related Strategies}

Fuel Blending. One of the problems encountered in simply switching from high-sulfur to low-sulfur coal is that changes in coal characteristics may have a profound effect on operation of the generating unit, affecting both boiler and pollution control equipment. To mitigate such effects and help keep overall operation within equipment design parameters, blending low-sulfur coal in the feedstock is a viable option. This approach, while effective in reducing $\mathrm{SO}_{2}$ emissions, is limited in the level of reduction it can provide. Reduction is constrained by the proportion of low-sulfur coal that can be introduced into the feedstock without significantly affecting overall system performance.

The cost of this approach is low compared to other, more effective $\mathrm{SO}_{2}$ control options. The main components are the cost of the delivered low-sulfur coal to be blended, the cost of modifications to coal-handling operations, costs to optimize or modify ESPs or particulate collection systems, and the cost of disposing of additional fly ash that may be generated. 
TABLE 3.3 Fuel Blending

\begin{tabular}{|c|c|}
\hline Issue & Impact on $\mathrm{SO}_{2}$ Control Strategy \\
\hline Sulfur dioxide & $\begin{array}{l}\text { Degree of control depends on how much high-sulfur fuel is replaced by } \\
\text { low-sulfur fuel in the blending process. }\end{array}$ \\
\hline Nitrogen dioxide & There is minimal impact on these emissions if the blended fuel is coal. \\
\hline Particulate matter & $\begin{array}{l}\text { Low-sulfur coal (especially from western U.S.) tends to have } \\
\text { characteristics that differ from high-sulfur eastern coal. Increased } \\
\text { emission of PM often results. In addition, the coal resistivity may also } \\
\text { change and degrade ESP collection efficiency. }\end{array}$ \\
\hline $\begin{array}{l}\text { Hazardous air } \\
\text { pollutants }\end{array}$ & $\begin{array}{l}\text { Changes to emissions of HAPs are dependent on composition of coal; } \\
\text { different coals may cause different HAP emission patterns. }\end{array}$ \\
\hline Carbon dioxide & There is minimal impact on these emissions if the blended fuel is coal. \\
\hline Copollutants & $\begin{array}{l}\text { Impacts include possible increased fly and bottom ash to dispose of and } \\
\text { possible impacts on HAPs. }\end{array}$ \\
\hline Cost & $\begin{array}{l}\text { Cost considerations include the incremental cost of low-sulfur coal, } \\
\text { transportaticn of the blend coal to the plant, and any necessary } \\
\text { redesign and alterations to the ESP and other coalflue-gas-handling } \\
\text { components. }\end{array}$ \\
\hline $\begin{array}{l}\text { Generating } \\
\text { capacity }\end{array}$ & $\begin{array}{l}\text { Blending may require a larger volume of coal to be fired for the same } \\
\text { power generated if the coal caloric content is lowered. This could } \\
\text { require ESP modifications to handle the increased fly ash load or } \\
\text { boiler derating so as not to overload the ESP. In addition, generating } \\
\text { capability could be constrained by coal-handling considerations if the } \\
\text { increased volume required is substantial. }\end{array}$ \\
\hline $\begin{array}{l}\text { Engineering } \\
\text { flexibility }\end{array}$ & $\begin{array}{l}\text { Possible impacts include physical procedures and space availability for } \\
\text { handling additional coal type(s) and alterations to ESPs. }\end{array}$ \\
\hline Visibility & $\begin{array}{l}\text { Reduced } \mathrm{SO}_{2} \text { emissions should result in improved visibility in affected } \\
\text { areas. }\end{array}$ \\
\hline Land use & $\begin{array}{l}\text { Possible impacts are increased ash disposal needs and planning for } \\
\text { handling multiple coal types at the plant. }\end{array}$ \\
\hline
\end{tabular}


TABLE 3.4 Fuel Switching

\begin{tabular}{|c|c|}
\hline Issue & Impact on $\mathrm{SO}_{2}$ Control Strategy \\
\hline Sulfur dioxide & Degree of control depends on sulfur content of the new coal. \\
\hline Nitrogen dioxide & $\begin{array}{l}\text { There is minimal impact on these emissions if the new fuel is coal; a } \\
\text { potential exists for reduced emissions if the new fuel is gas. }\end{array}$ \\
\hline Particulate matter & $\begin{array}{l}\text { Low-sulfur coal (especially from western U.S.) tends to have } \\
\text { characteristics that differ from high-sulfur eastern coal. Increased } \\
\text { emission of PM often results. In addition, the coal resistivity may also } \\
\text { change and degrade ESP collection efficiency. }\end{array}$ \\
\hline $\begin{array}{l}\text { Hazardous air } \\
\text { pollutants }\end{array}$ & $\begin{array}{l}\text { Changes to emissions of } \mathrm{HAPs} \text { are dependent on composition of coal; } \\
\text { different coals may cause different HAP emission patterns. }\end{array}$ \\
\hline Carbon dioxide & $\begin{array}{l}\text { There is minimal impact on these emissions if the new fuel is coal; a } \\
\text { potential exists for reduced emissions if the new fuel is gas. }\end{array}$ \\
\hline Copollutants & $\begin{array}{l}\text { Impacts include possible increased fly and bottom ash to dispose of and } \\
\text { possible impacts on HAPs. Water pollution from runoff and plant-use } \\
\text { water could increase. }\end{array}$ \\
\hline Cost & $\begin{array}{l}\text { Cost considerations include the incremental cost of low-sulfur coal, } \\
\text { possible increased cost of transportation of the new coal to the plant, } \\
\text { and any necessary redesign and alterations to the ESP and other } \\
\text { coal/flue-gas-handling components. }\end{array}$ \\
\hline $\begin{array}{l}\text { Generating } \\
\text { capacity }\end{array}$ & $\begin{array}{l}\text { Fuel switching may require a larger volume of coal to be fired for the } \\
\text { same power generated if the coal caloric content is lowered. This could } \\
\text { require ESP modifications to handle the increased fly ash load or boiler } \\
\text { derating so as not to overload the ESP. Also, the boiler heat rate could } \\
\text { be adversely affected if redesign is required to accommodate the new } \\
\text { coal. Generating capability could be constrained by coal-handling } \\
\text { considerations if the increased volume required is substantial. }\end{array}$ \\
\hline $\begin{array}{l}\text { Engineering } \\
\text { flexibility }\end{array}$ & $\begin{array}{l}\text { Possible impacts include physical procedures and space availability for } \\
\text { handling additional coal type(s) and alterations to ESPs. Boiler } \\
\text { redesign needs may be a consideration. }\end{array}$ \\
\hline Visibility & $\begin{array}{l}\text { Reduced } \mathrm{SO}_{2} \text { emissions should result in improved visibility in affected } \\
\text { areas. }\end{array}$ \\
\hline Land use & $\begin{array}{l}\text { Possible impacts are increased ash disposal and coal-handling } \\
\text { considerations. }\end{array}$ \\
\hline
\end{tabular}


TABLE 3.5 Gas Cofiring

\begin{tabular}{|c|c|}
\hline Issue & Impact on $\mathrm{SO}_{2}$ Control Strategy \\
\hline Sulfur dioxide & $\begin{array}{l}\text { There is a potentially significant reduction of emissions from } \\
\text { replacement of sulfur-containing fuel (coal) with nearly sulfur-free fuel. }\end{array}$ \\
\hline Nitrogen dioxide & $\begin{array}{l}\text { There is a potential reduction of emissions, depending on burner } \\
\text { characteristics. }\end{array}$ \\
\hline Particulate matter & $\begin{array}{l}\text { Potential impacts include reduction of emissions and reduction of load } \\
\text { on particulate control equipment. }\end{array}$ \\
\hline $\begin{array}{l}\text { Hazardous air } \\
\text { pollutants }\end{array}$ & $\begin{array}{l}\text { There is a potential for reduction of emissions, as gas is inherently } \\
\text { cleaner than coal. }\end{array}$ \\
\hline Carbon dioxide & $\begin{array}{l}\text { There is a potential for reduction of emissions, as gas contains less } \\
\text { carbon than coal. }\end{array}$ \\
\hline Copollutants & $\begin{array}{l}\text { There is a potential for reduction of fly ash generation and disposal } \\
\text { needs. }\end{array}$ \\
\hline Cost & $\begin{array}{l}\text { Costs include those for burner modifications and gas transportation. } \\
\text { Also, gas generally costs more than coal. }\end{array}$ \\
\hline $\begin{array}{l}\text { Generating } \\
\text { capacity }\end{array}$ & $\begin{array}{l}\text { Generally, little adverse impact is expected from any variation of gas } \\
\text { cofiring, although a boiler switched from coal to gas may experience a } \\
\text { decrease in efficiency. }\end{array}$ \\
\hline $\begin{array}{l}\text { Engineering } \\
\text { flexibility }\end{array}$ & $\begin{array}{l}\text { This is one of the more flexible options in terms of allowing changes } \\
\text { without great cost. }\end{array}$ \\
\hline Visibility & $\begin{array}{l}\text { Reduced } \mathrm{SO}_{2} \text { emissions should result in improved visibility in affected } \\
\text { areas. }\end{array}$ \\
\hline Land use & A potential benefit is reduced land needed for ash disposal. \\
\hline
\end{tabular}


TABLE 3.6 Coal Cleaning

\begin{tabular}{|c|c|}
\hline Issue & Impact on $\mathrm{SO}_{2}$ Control Strategy \\
\hline Sulfur dioxide & $\begin{array}{l}\text { Although not sufficiently effective to be considered a primary strategy, } \\
\text { cleaning nonetheless can remove a significant portion of the pyritic } \\
\text { sulfur in coal, thus lowering the sulfur (S) content of boiler fuel. }\end{array}$ \\
\hline Nitrogen dioxide & A minimal effect on this pollutant is expected. \\
\hline Particulate matter & $\begin{array}{l}\text { Cleaning will reduce the ash content of the boiler fuel, and thus the } \\
\text { load on the control equipment will be reduced. Total PM emissions } \\
\text { should drop, but ESP operation will require additional attention. }\end{array}$ \\
\hline $\begin{array}{l}\text { Hazardous air } \\
\text { pollutants }\end{array}$ & $\begin{array}{l}\text { Some HAPs will be reduced because the volume of precursor material } \\
\text { entering the combustion chamber will be reduced. }\end{array}$ \\
\hline Carbon dioxide & $\begin{array}{l}\text { The higher quality fuel being input to the boiler may lead to higher } \\
\text { combustion efficiency and an increase in } \mathrm{CO}_{2} \text { emissions. }\end{array}$ \\
\hline Copollutants & At the cleaning plant, process water will need treatment. \\
\hline Cost & Relative costs will be low, but cleaning is only part of the solution. \\
\hline $\begin{array}{l}\text { Generating } \\
\text { capacity }\end{array}$ & $\begin{array}{l}\text { Cleaning generally leads to a higher energy density and more constant } \\
\text { characteristics of the feedstock. }\end{array}$ \\
\hline $\begin{array}{l}\text { Engineering } \\
\text { flexibility }\end{array}$ & $\begin{array}{l}\text { The major impact on flexibility will be the ESP design modifications } \\
\text { required by altered coal characteristics. }\end{array}$ \\
\hline Visibility & $\begin{array}{l}\text { Reduced } \mathrm{SO}_{2} \text { emissions should result in improved visibility in affected } \\
\text { areas. }\end{array}$ \\
\hline Land use & Minimal impacts are expected. \\
\hline
\end{tabular}


TABLE 3.7 Wet Lime/Limestone Flue Gas Desulfurization

\begin{tabular}{|c|c|}
\hline Issue & Impact on $\mathrm{SO}_{2}$ Control Strategy \\
\hline Sulfur dioxide & Removal efficiencies typically range from 80 to $95 \%$. \\
\hline Nitrogen dioxide & $\begin{array}{l}\text { No reduction is normally expected, although use of certain sorbent } \\
\text { additives has been shown to result in reduction. }\end{array}$ \\
\hline Particulate matter & $\begin{array}{l}\text { This technology will capture particulate matter entrained in the flue } \\
\text { gas. }\end{array}$ \\
\hline $\begin{array}{l}\text { Hazardous air } \\
\text { pollutants }\end{array}$ & $\begin{array}{l}\text { This technology has good capability for capturing air toxics such as } \\
\text { acid gases. }\end{array}$ \\
\hline Carbon dioxide & $\begin{array}{l}\text { The limestone process is a source of } \mathrm{CO}_{2} \text { emissions, although the level } \\
\text { is quite small compared to the amount generated by coal combustion; } \\
\text { however, FGD systems have parasitic energy requirements, reducing } \\
\text { electricity output per Btu combusted. }\end{array}$ \\
\hline Copollutants & $\begin{array}{l}\text { The process generates a large volume of solids to dispose of, as well as } \\
\text { wastewater to be treated. }\end{array}$ \\
\hline Cost & $\begin{array}{l}\text { There are high energy and operating costs associated with this } \\
\text { technology. The cost to implement is affected by location, type of PM } \\
\text { control device used, and degree of difficulty retrofitting the equipment } \\
\text { to the plant. }\end{array}$ \\
\hline Generation issues & $\begin{array}{l}\text { This technology requires energy to operate, which reduces the net } \\
\text { amount of electricity available for distribution. Maximizing capture of } \\
\text { pollutants increases energy usage. }\end{array}$ \\
\hline $\begin{array}{l}\text { Engineering } \\
\text { flexibility }\end{array}$ & $\begin{array}{l}\text { Because of its high control efficiency, this technology fits well with a } \\
\text { variety of coals. Use of this technology results in limited operating } \\
\text { flexibility after installation. }\end{array}$ \\
\hline Visibility & $\begin{array}{l}\text { Reduced } \mathrm{SO}_{2} \text { emissions should result in improved visibility in affected } \\
\text { areas. }\end{array}$ \\
\hline Land use & This technology will increase the requirements for land-based disposal. \\
\hline
\end{tabular}


TABLE 3.8 Spray Drying

\begin{tabular}{ll}
\hline \multicolumn{1}{c}{ Issue } & \multicolumn{1}{c}{ Impact on $\mathrm{SO}_{2}$ Control Strategy } \\
\hline Sulfur dioxide & Removal efficiencies typically range from 70 to $90 \%$. \\
Nitrogen dioxide & $\begin{array}{l}\text { No reduction is expected from conventional process, although use of a } \\
\text { sodium additive has shown a reduction in the 20-40\% range. }\end{array}$ \\
Particulate matter & $\begin{array}{l}\text { This technology requires the use of a particulate control system to } \\
\text { collect the sorbent. An existing ESP will likely require modifications } \\
\text { to handle the increased particulate loading that results. }\end{array}$ \\
$\begin{array}{l}\text { Hazardous air } \\
\text { pollutants }\end{array}$ & $\begin{array}{l}\text { This technology also collects acid gases and metals. } \\
\text { Carbon dioxide }\end{array}$ \\
$\begin{array}{l}\text { There is minimal impact on these emissions. } \\
\text { Copollutants }\end{array}$ & $\begin{array}{l}\text { The by-product from this technology is the solids. } \\
\text { Cost }\end{array}$ \\
$\begin{array}{l}\text { Costs are significantly affected by site-specific considerations but are } \\
\text { normally less than a wet FGD process, although this may not be true } \\
\text { if the existing ESP is no longer usable or requires extensive } \\
\text { modification. }\end{array}$ \\
$\begin{array}{l}\text { A portion of the plant output energy is required to operate the system. } \\
\text { Generating }\end{array}$ \\
$\begin{array}{l}\text { A sopacity } \\
\text { Engineering }\end{array}$
\end{tabular}


TABLE 3.9 Sorbent Injection

\begin{tabular}{ll}
\multicolumn{1}{c}{ Issue } & \multicolumn{1}{c}{ Impact on $\mathrm{SO}_{2}$ Control Strategy } \\
\hline Sulfur dioxide & $\begin{array}{l}\text { This technology's efficiency ranges from } 40 \text { to } 70 \% \text {. The technology is } \\
\text { normally effective as a supplemental control strategy only. }\end{array}$ \\
Nitrogen dioxide & Minimal ability to collect this pollutant has been demonstrated. \\
Particulate matter & $\begin{array}{l}\text { This technology requires the use of a particulate control system to } \\
\text { collect the sorbent. An existing ESP will likely require modifications } \\
\text { to handle the increased particulate loading that results. }\end{array}$ \\
Hazardous air & $\begin{array}{l}\text { This technology has been shown to collect acid gases. } \\
\text { pollutants }\end{array}$ \\
Carbon dioxide & $\begin{array}{l}\text { There is minimal impact on these emissions. } \\
\text { Copollutants }\end{array}$ \\
$\begin{array}{l}\text { The by-products from this technology are the spent sorbent solids and } \\
\text { unreacted sorbent in the fly ash. }\end{array}$ \\
Cost
\end{tabular}


TABLE 3.10 Wet Regenerable Flue Gas Desulfurization

\begin{tabular}{|c|c|}
\hline Issue & Impact on $\mathrm{SO}_{2}$ Control Strategy \\
\hline Sulfur dioxide & $\begin{array}{l}\text { Removal efficiencies are typically high. For the Wellman-Lord } \\
\text { process, removal efficiency can exceed } 95 \% \text {. }\end{array}$ \\
\hline Nitrogen dioxide & Minimal ability to collect this pollutant has been demonstrated. \\
\hline Particulate matter & This technology will capture PM entrained in the flue gas. \\
\hline $\begin{array}{l}\text { Hazardous air } \\
\text { pollutants }\end{array}$ & This technology is effective for capturing acid gases. \\
\hline Carbon dioxide & $\begin{array}{l}\text { Minimal direct impact on generation or collection of this species is } \\
\text { expected. }\end{array}$ \\
\hline Copollutants & $\begin{array}{l}\text { The process generates a large volume of solids to dispose of, as well } \\
\text { as wastewater to be treated. }\end{array}$ \\
\hline Cost & $\begin{array}{l}\text { There are high energy and operating costs associated with this } \\
\text { technology. It is more coetly to install than a wet nonregenerable } \\
\text { method because of additional needs for processing the regenerated } \\
\text { product. Operating costs are mitigated by the value of the } \\
\text { regenerated product. }\end{array}$ \\
\hline $\begin{array}{l}\text { Generating } \\
\text { capacity }\end{array}$ & $\begin{array}{l}\text { This technology requires energy to operate, which reduces the net } \\
\text { amount of electricity available for distribution. Maximizing capture } \\
\text { of pollutants increases energy usage. }\end{array}$ \\
\hline $\begin{array}{l}\text { Engineering } \\
\text { flexibility }\end{array}$ & $\begin{array}{l}\text { Because of its high control efficiency, this technology fits well with a } \\
\text { variety of coals. Use of this technology results in limited operating } \\
\text { flexibility after installation. }\end{array}$ \\
\hline Visibility & $\begin{array}{l}\text { Reduced } \mathrm{SO}_{2} \text { emissions should result in improved visibility in affected } \\
\text { areas. }\end{array}$ \\
\hline Land use & $\begin{array}{l}\text { This technology will increase the requirements for land-based } \\
\text { disposal. Additional space is required to install and operate the } \\
\text { product recovery system. }\end{array}$ \\
\hline
\end{tabular}


TABLE 3.11 Boiler Repowering

\begin{tabular}{|c|c|}
\hline Issue & Impact on $\mathrm{SO}_{2}$ Control Strategy \\
\hline Sulfur dioxide & $\begin{array}{l}\text { The various options for repowering existing units yield efficiencies for } \\
\mathrm{SO}_{2} \text { removal that exceed } 90 \% \text {. }\end{array}$ \\
\hline Nitrogen dioxide & $\begin{array}{l}\text { These options also have good potential for control of } \mathrm{NO}_{2} \text {. Reported } \\
\text { values indicate } \mathrm{NO}_{\mathrm{x}} \text { emissions from fluidized-bed combustion (FBC) } \\
\text { furnaces are } 20-30 \% \text { the magnitude of emissions from conventional } \\
\text { furnaces. }\end{array}$ \\
\hline Particulate matter & $\begin{array}{l}\text { Repowering options will require particulate control equipment to } \\
\text { capture a portion of the sorbent. This may require modifications to } \\
\text { PM collection systems to operate properly and to avoid increasing PM } \\
\text { emissions. }\end{array}$ \\
\hline $\begin{array}{l}\text { Hazardous air } \\
\text { pollutants }\end{array}$ & $\begin{array}{l}\text { There may be some control of acid gases and metals due to the nature } \\
\text { of the combined } \mathrm{SO}_{2} \text { and PM control processes. }\end{array}$ \\
\hline Carbon dioxide & $\begin{array}{l}\text { Greater conversion efficiencies will lead to less } \mathrm{CO}_{2} \text { per unit of } \\
\text { electricity produced. }\end{array}$ \\
\hline Copollutants & $\begin{array}{l}\text { There will be an increase in solids requiring disposal unless this } \\
\text { option replaces an existing FGD system. Unreacted sorbent (lime) in } \\
\text { the spent solids stream could complicate disposal. }\end{array}$ \\
\hline Cost & $\begin{array}{l}\text { These repowering options are more costly to install and operate than } \\
\text { their older technology counterparts, assuming the units to be replaced } \\
\text { are not already using FGD. Capital costs rise as } \mathrm{SO}_{2} \text { capture } \\
\text { efficiency rises. }\end{array}$ \\
\hline $\begin{array}{l}\text { Generating } \\
\text { capacity }\end{array}$ & $\begin{array}{l}\text { Except for atmospheric } \mathrm{FBC} \text {, the common repowering options } \\
\text { generally provide increased plant capacity, since the furnace designs } \\
\text { are much improved over those they are replacing. The range is from } \\
25 \text { to } 300 \% \text {. Heat rates also increase by a small percentage for } \\
\text { several of these options. At the upper range of } \mathrm{SO}_{2} \text { control, heat rate } \\
\text { may decrease slightly. }\end{array}$ \\
\hline $\begin{array}{l}\text { Engineering } \\
\text { flexibility }\end{array}$ & $\begin{array}{l}\text { Degree of flexibility varies by methodology used. Atmospheric FBC is } \\
\text { simpler than others, and FBC allows the use of low-grade coal as fuel. } \\
\text { Integrated gasification combined-cycle (IGCC) technology is more } \\
\text { complex, since it employs a new gas turbine but provides the greatest } \\
\text { increase to plant capacity. }\end{array}$ \\
\hline Visibility & $\begin{array}{l}\text { Reduced } \mathrm{SO}_{2} \text { emissions should result in improved visibility in affected } \\
\text { areas. }\end{array}$ \\
\hline Land use & $\begin{array}{l}\text { There will be an increased requirement for land-based disposal of the } \\
\text { spent sorbent. Additional space would be required for locating the gas } \\
\text { turbine if the IGCC option is chosen. }\end{array}$ \\
\hline
\end{tabular}


Regarding pollutant generation, fuel blending may result in increased ash formation. Particulate control systems may require modification to keep emissions of particulate matter (PM) within allowable limits. In addition, different coal mineral contents may affect the types and levels of HAPs produced during combustion and possibly emitted (Szpunar 1992). An increase in ash will present disposal problems, and there may be water treatment considerations from runoff and plant water use.

In general, fuel blending is straightforward to implement. The appropriate types of coal and proportions of blend available to a utility are limited by equipment characteristics and the ease of modification needed to accommodate the blended fuel stream. There may also be increased coal-handling and preparation considerations.

Fuel Switching. The level of $\mathrm{SO}_{2}$ emissions from coal-fired boilers is directly related to the amount of sulfur in the coal. Thus, the simplest way of reducing $\mathrm{SO}_{2}$ emissions is to use coal with a lower sulfur content; however, several considerations affect this choice, including availability, cost, and engineering impacts. The engineering considerations are related to coal characteristics, handling, equipment performance, and disposal of waste products. Low-sulfur coal may present significantly increased fire and explosion risks as well. Careful planning and preparation are essential for successful coal-switching projects.

In one report of several case studies of coal conversion, capital costs (in 1990 dollars) ranged from $\$ 23$ to $\$ 102 / \mathrm{kW}$ for plants converting to eastern or western low-sulfur coals (Rupinskas and Hiller 1992). The costs resulted from required changes to PM control equipment, pulverizer changes, fire protection modifications, and dust control measures.

Depending on coal characteristics, switching may lead to increased ash formation. This depends on the coal's ash content and its higher heating value (HHV). With a lower HHV, a higher mass of coal will have to be fed into the furnace to generate the same amount of heat. Particulate control systems may require modification to keep emissions of PM within allowable limits. In addition, different coal mineral content may affect the types and levels of HAPs produced during combustion and possibly emitted. An increase in ash will present disposal problems, and there may be water treatment considerations from runoff and plant water use.

Fuel switching requires careful planning and preparation to implement. The coal selected for use must be matched to existing equipment, or modifications must be made to accommodate the low-sulfur feedstock. Plant modifications may include boiler derating resulting from limitations posed by existing PM control equipment or necessary heat rate changes. A utility's flexibility to respond to possible future changes may be hampered by physical processes and boiler modifications implemented to accommodate a new coal type.

Gas Cofiring. Natural gas is probably the cleanest and most potent of the fossil fuels available for use in power generation. Cofiring is a convenient and straightforward means of achieving $\mathrm{SO}_{2}$ reductions; however, while current natural gas availability and price 
appear favorable, it is likely that competition for supplies from utilities, industry, cogenerators, and independent power producers will push prices up. Also, gas producers are not aggressively developing new reserves and are not likely to do so until prices rise. Access to a nearby pipeline is another requirement for this option to be economic. For these reasons, cew utilities appear to be ready to resort to gas cofiring or seasonal firing to achieve compliance (Makansi 1991). Natural gas firing has generally lower capital costs, as well as lower operation and maintenance costs, but higher fuel costs than coal firing.

In addition to its extremely low $\mathrm{SO}_{2}$ emissions, lower levels of other pollutants are also characteristic of firing natural gas. It emits lower levels of $\mathrm{NO}_{\mathrm{x}}, \mathrm{CO}, \mathrm{CO}_{2}$, and $\mathrm{PM}$ and does so without auxiliary control equipment. Gas contains fewer impurities that can lead to air toxics as well.

Few coal-fired boilers today are designed to cofire natural gas; however, many could be retrofitted. This is generally done with separate burners for gas and coal. Thus, if it were desirable to stop burning gas, the boilers would not have to be modified again for coal-only firing. This option provides a great deal of flexibility for the utility but does so at a cost many may not be willing to pay.

Coal Cleaning. This technology is the physical separation of combustible organic matter in coal from the noncombustible mineral matter. Most coal is prepared in some manner before firing, even if only by gravimetric separation of the larger size fractions in a jig plant. Several advanced cleaning processes are available for further enhancement of coal, including advanced froth flotation, true heavy liquid beneficiation, electrostatic separation, fine-coal cycloning, high-gradient magnetic separation, and selective agglomerization; however, it is not likely that coal cleaning alone can economically reduce $\mathrm{SO}_{2}$ emissions enough to be a complete compliance strategy. Cleaning may change coal characteristics enough to require modifications to the ESP, if one exists.

Costs for coal cleaning are relatively low compared to FGD. They have been estimated to range from $\$ 137$ to $\$ 549 /$ metric ton of $\mathrm{SO}_{2}$ reduced, depending on the cleaning methodology used and the initial sulfur content of the coal (South et al. 1990).

Advanced cleaning processes are capable of a 35-65\% reduction of $\mathrm{SO}_{2}$ emissions and a $45-70 \%$ reduction of total ash. The cleaned coal has a higher heating value as well, which can be $25 \%$ or more above the raw coal heating value. Because the cleaned coal may be expected to burn more efficiently, an increase in $\mathrm{CO}_{2}$ emissions may be expected, but the increased conversion efficiency may offset the increase. In addition, cleaning removes many of the coal's trace elements with other mineral matter and thus reduces the production of air toxics.

Coal cleaning affords some flexibility in the selection of coal the plant will use, but different cleaning techniques are more suitable to certain coal types, so installing a cleaning process implies a commitment to a fixed range of coal types. Advanced coal-cleaning techniques are improving by virtue of interest and sponsorship by EPRI and DOE. 


\subsubsection{Flue Gas Treatment}

Flue gas desulfurization (FGD) is expected to be a common strategy selected by utility companies to comply with environmental regulations. Intense competition between system and component suppliers is currently acting to control FGD system costs. The costs per ton of $\mathrm{SO}_{2}$ removed are close among the various wet control techniques. Although dry removal techniques have lower capital costs than wet ones, they are more costly per ton of $\mathrm{SO}_{2}$ removed. Experience in the design and use of FGD strategies has shown that design simplifications can reduce the capital cost of conventional FGD by as much as $30 \%$ (Radcliffe 1992). Table 3.12 presents the comparative costs of several $\mathrm{SO}_{2}$ removal methods.

Wet Lime/Limestone FGD. Wet limestone FGD is the most popular technique of flue gas scrubbing in the United States today. These processes are generally applicable to any coal-fired boiler. The typical system uses a calcium-based sorbent, lime or limestone, and

TABLE 3.12 Comparison of $\mathrm{SO}_{2}$ Removal Methodologies

\begin{tabular}{|c|c|c|c|}
\hline $\begin{array}{c}\mathrm{SO}_{2} \text { Reduction } \\
\text { Option }\end{array}$ & $\begin{array}{c}\text { Capital } \\
\text { Cost } \\
(\$ / k W)\end{array}$ & $\begin{array}{c}\text { Levelized } \\
\text { Cost } \\
\text { (mills/kWh) }\end{array}$ & $\begin{array}{c}\text { Levelized } \\
\text { Cost } \\
\text { (\$/ton removed) }\end{array}$ \\
\hline \multicolumn{4}{|l|}{ Furnace injection } \\
\hline Limestone & 25-50 & $5-15$ & $450-800$ \\
\hline Hydrated lime & $25-50$ & $5-20$ & $600-1,200$ \\
\hline \multicolumn{4}{|l|}{ Economizer injection } \\
\hline Hydrated lime & $25-50$ & $5-20$ & $600-1,200$ \\
\hline \multicolumn{4}{|l|}{ Duct injection } \\
\hline Hydrated lime & 25-50 & $5-20$ & $600-1,500$ \\
\hline Sodium bicarbonate & $25-50$ & $10-30$ & $1,200-2,000$ \\
\hline Sodium sesquicarbonate & $25-50$ & $10-25$ & $1,000-1,800$ \\
\hline Spray drying & $150-250$ & $10-30$ & $350-600$ \\
\hline Wet FGD & $175-350$ & $12-25$ & $400-1,400$ \\
\hline Fuel switching & $25-100$ & $10-25$ & $400-900$ \\
\hline Coal blending & $25-75$ & $10-20$ & $300-700$ \\
\hline Coburning & $15-20$ & $5-10$ & $1,000-2,000$ \\
\hline Coal cleaning & $30-60$ & $2-12$ & $350-1,000$ \\
\hline
\end{tabular}

Source: Adapted from Research-Cottrell Companies, Inc., Coal \& Synfuels Technology, March 18, 1991. 
is designed for $80-95 \% \mathrm{SO}_{2}$ removal efficiency. Some limestone systems produce marketable gypsum. Various additives can be used to increase removal efficiency.

Retrofitting a wet scrubber can be a costly project, and space considerations can make it more so. In the past, a spare scrubbing module has been included to minimize downtime, but because of increased reliability, the current practice is to avoid the cost of spare modules. Operation costs of wet FGD are high also, especially as efficiency is pushed to the limit. Parasitic electrical usage can be as much as $1.5 \%$.

In addition to high $\mathrm{SO}_{2}$ removal efficiency, wet FGD will remove $\mathrm{PM}$ as well and can also control air toxics such as acid gases. The limestone process is a source of $\mathrm{CO}_{2}$ emissions, albeit a small one compared to coal combustion. Secondary considerations for retrofitting these systems are the need for waste disposal for ash, water consumption and discharge, and by-product use. Space must be made available for equipment and disposal activities.

The high $\mathrm{SO}_{2}$ removal efficiency allows use of most coal the boiler is capable of firing, although design efficiencies of $\mathrm{SO}_{2}$ and $\mathrm{PM}$ are dependent on flue gas $\mathrm{SO}_{2}$ concentration and particle size. Because of high capital costs, installation of a wet FGD system implies a strong commitment to scrubbing and limits the flexibility of the compliance strategy should future circumstances warrant consideration of changes.

Wet Regenerable FGD. Wet regenerable FGD processes, like the wet lime and limestone processes, use a wet scrubbing methodology and are capable of high $\mathrm{SO}_{2}$ removal rates; however, the wet regenerable processes are designed to recover a sulfur product such as sulfuric acid or elemental sulfur. In addition, they have a minimal wastewater discharge stream. The two most common types of wet regenerable processes in use in the United States today are the Wellman-Lord and the magnesium oxide processes. They are most often installed when a nearby market for the products already exists. This technology, in addition to having a very high $\mathrm{SO}_{2}$ removal capability, is capable of controlling $\mathrm{PM}$ emissions and HAPs such as acid gases.

Capital costs are higher because of the additional requirement for sulfur recovery equipment. Ease of retrofitting is similar to that of retrofitting a regenerable system. Operation diverts some generating capacity for use by the FGD system. Operating costs are offset by the value of the recovered sulfur product. For regenerable technologies, plant space requirements exceed those for nonregenerable ones; however, virtually no space is required for waste disposal. Retrofit decisions are strongly influenced by the existence of a by-product market and the value of the by-product. A decision to implement a wet regenerable process requires a strong, long-term commitment.

Spray Dryer. Spray drying techniques have been used by industry for many years for manufacturing powdered milk, powdered coffee, detergents, and a wide variety of other products. Such techniques start with a wet scrubbing medium but use hot gases to dry the 
scrubbed mixture by evaporating the entrained moisture. The dried stream requires subsequent treatment for particulate removal, usually with a baghouse or ESP.

Capital costs for these systems are often lower than costs for a wet FGD system, but in retrofitting a spray dryer, the additional PM loading must be taken into consideration. If the existing PM control system is not capable of handling the additional loading, it must be upgraded, or PM emissions will increase. Spray dryers typically use lime or other reagents for scrubbing that are more expensive than limestone. The process becomes uneconomic when coal sulfur content exceeds 3\% (Makansi 1991); however, a spray dryer is simpler to operate, and the by-product waste disposal requirements are also much simpler compared to wet FGD.

The $\mathrm{SO}_{2}$ removal efficiency of the process ranges from 70 to $90 \%$. As mentioned earlier, PM emissions can rise unless particular care is made in watching the PM control system to the spray dryer. The combination of spray dryer and PM control is capable of controlling acid gases and metals as well. The dry waste produced is easier to dispose of than the wet slurry waste from other FGD processes.

Sorbent Injection. The application of sorbent injection methods is generally considered to be a retrofit option, rather than a new source control strategy. A good deal of flexibility is allowed: injection can be done at several points, including the furnace, the convective pass area, and ductwork; however, the relatively low capture efficiency (40-70\%) has so far relegated the applications of this technology to a limited sector - usually plants that are nearing retirement, are small or used at low capacity, do not have a high $\mathrm{SO}_{2}$ control requirement, or are near an abundant source of reagent. Research using sodium-based reagents (instead of the more traditional calcium-based ones) shows promise of $\mathrm{SO}_{2}$ removal efficiencies up to $90 \%$.

Use of sorbent injection dictates use of a reliable PM collection system, as used sorbent is easily entrained in the flue gas stream. Like other forms of FGD, this process captures acid gases, as well as $\mathrm{SO}_{2}$. The process produces solid waste to be disposed of, and the fly ash will have some measure of unreacted so. oent in it.

Capital costs are relatively low, but operating costs can be so high as to make purchase of allowances on the open market a competitive option. One reason for high operating costs is that the dry injection process lacks a gas-liquid-oolid mass transfer interface and thus requires a higher volume of sorbent in order to achieve the same level of $\mathrm{SO}_{2}$ removal as wet systems (Farber 1992). While the process is simple to install and requires little space, the increased solids loading and potential need for flue gas humidification (when used with an ESP) are distinct disadvantages. Ductwork fouling is another concern. Solid waste quantities will increase, as will the degree of treatment necessary for the solids. 


\subsubsection{Boiler Repowering}

This option entails replacing the furnace of an existing boiler with one of the various modern technologies that are designed to minimize emission of air pollutants. The two variations of repowering most commonly considered are fluidized-bed combustion (FBC) and coal gasification with combined cycle (GCC). Current thinking is that optimum size for FBC is about $300 \mathrm{MW}$ (Smith 1991). An FBC furnace operates much like a scrubber system in that a sorbent is used to collect $\mathrm{SO}_{2}$, but the collection is done during combustion. The GCC converts coal to gas, and the gas is burned in a gas turbine. The addition of the gas turbine has the effect of increasing overall plant capacity.

As might be expected, boiler repowering options provide an opportunity to design control capability for more than one pollutant. The main opportunity here is the simultaneous control of $\mathrm{NO}_{\mathrm{x}}$. Removal efficiencies can exceed $95 \%$ for $\mathrm{SO}_{2}$ (even higher for GCC), while $\mathrm{NO}_{\mathrm{x}}$ emissions from FBC furnaces are 20-30\% of levels from conventional furnaces (South et al. 1990). Because of sorbent use, FBC furnaces require PM control systems; however, the technolugy provides some control of acid gases and metals. Solid waste from these furnaces will contain unreacted sorbent, normally in the form of lime, which will complicate disposal procedures.

Although there are few repowered units from which to draw data, GCC repowering will obviously have high capital costs, since a gas turbine will need to be provided. Operating costs will also increase. In general, the higher the $\mathrm{SO}_{2}$ removal rate designed for, the higher the capital cost and the lower the heat rate of the unit.

These technologies can also have a profound effect on plant capacities. The FBC can increase capacity by an average of $25 \%$, while GCC can provide increases as high as $300 \%$. Heat rates can improve by $5-20 \%$ or more, depending on which technology is employed. An exception to this is an FBC operated at atmospheric pressure; these furnaces are simpler and cheaper but provide less improvement.

The FBC furnaces require an increase in land disposal area for the spent sorbent. The GCC plants require space for the gas turbine and attendant equipment. 


\section{ENVIRONMENTAL POLICY INTERACTIONS AND

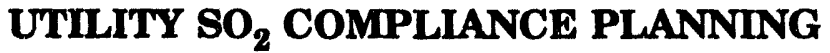

As the foregoing sections have shown, the Title $\mathrm{IV} \mathrm{SO}_{2}$ program will not operate in a vacuum. Utility compliance with the program will be a multifaceted process influenced by other environmental programs, rate regulation, compliance and allowance treatment, fuel and allowance prices, and possible cocontrols. All of these factors are making $\mathrm{SO}_{2}$ compliance planning problematic.

\subsection{COMPLIANCE PLANNING UNDER MULTIPLE REGULATIONS}

One may think of the CAAA as setting a stair-step approach to the regulation of utilities. The regulations increase the severity of controls with each successive step, adding reductions beyond those already achieved:

- Step 1. Pursuant to the 1970 and 1977 Acts, the EPA promulgated ambient air quality standards for criteria pollutants; utilities are most affected by ambient standards for particulates, $\mathrm{SO}_{2}$, and $\mathrm{NO}_{\mathbf{x}}$. In the CAAA, Title I, Congress tightens procedures for attainment of these standards, so that some states will force additional controls upon local utilities.

- Step 2. Pursuant to the CAAA, Title IV, the EPA is promulgating regulations for acid rain control (see Appendix, Table A.1); utilities have begun installing controls for Phase I compliance, and compliance planning is beginning for Phase II; proposals for $\mathrm{NO}_{x}$ emission limits have been published under Title I and Title IV. Further $\mathrm{NO}_{\mathrm{x}}$ reductions may be mandated by state implementation plans (SIPs).

- Step 3. Pursuant to the CAAA, Title III, the EPA may, given certain findings, promulgate standards for air toxics from utilities; but recognizing that some of the technologies implemented for criteria pollutants or acid rain control will cocontrol HAPs, Congress commanded the EPA to promulgate regulations for utilities only if, after examining whether the controls already installed will reduce HAP emissions to acceptable levels, the remaining risk warrants regulation (analogous to residual risk) [Section $112(\mathrm{n})(1)$ ]. Given that some of the air toxics from utilities (e.g., $\mathrm{Hg}$ ) may not be controlled by technologies in the prior steps, at least some utility regulation is possible. Retrofit requirements associated with the visibility program may also grow, depending on the ability of present programs to improve visibility in Class I areas (Loeb and Elliott, in press). Stricter requirements of utility emissions of $\mathrm{SO}_{2}$ and $\mathrm{NO}_{2}$ in 1993 may be issued by the EPA. Potentially, all of these rules will have compliance deadlines that fall between 1995 (the start 
of Phase I acid rain control, and 2000, the start of Phase II of acid rain control. In the meantime, these issues produce significant uncertainties for utility $\mathrm{SO}_{2}$ compliance planning.

- Step 4. While no environmental legislation has specifically addressed the issue of greenhouse gas (GHG) control, the scientific uncertainty surrounding the problem, along with several groups pursuing GHG control, may lead to control of utility $\mathrm{CO}_{2}$ emissions in the future. The timing of the legislation and resulting regulation is uncertain, although its impacts (if enacted) will occur in Phase II and beyond. Of all of the environmental regulation related to utilities, control of GHGs is the most uncertain.

Other issues that may arise in the stair-step CAAA approach will be the effectiveness of the $\mathrm{SO}_{2}$ program in reducing acidic deposition and the possibility of widespread use of externality adders by PUCs. The quasi-property-right nature of $\mathrm{SO}_{2}$ emission allowances allows the Congress to more easily reduce the total number of allowances and, hence, reduce the aggregate level of $\mathrm{SO}_{2}$ emission. If decreases in lake and stream acidification and in high-elevation foliage loss and improvements in visibility (due to decreased $\mathrm{SO}_{2}$ ) do not occur, the $\mathrm{SO}_{2}$ cap may be more restrictive in the future. In addition, environmental externalities are currently being considered in a number of states (Cohen et al. 1990). These programs would presumably internalize the costs of utility emissions in order to develop a "cleaner" mix of generation resources. ${ }^{100}$

As described in Section 2, the Title IV $\mathrm{SO}_{2}$ program allows significant compliance flexibility. The program requires only that $\mathrm{SO}_{2}$ emission allowances held must be greater than or equal to actual annual $\mathrm{SO}_{2}$ emissions, without specifying the means by which that may take place. Title IV provides only minimal constraints to affected units' objective of minimizing control costs; however, constraints to that objective do arise; for example, Title I limits $\mathrm{SO}_{2}$ (and other criteria pollutant) emissions at each plant, so that local ambient standards are not violated. ${ }^{101}$ Complicating the cost minimization process are fluctuations in delivered fuel prices, allowance prices, and energy demand. ${ }^{102}$ Under the $\mathrm{SO}_{2}$ program (along with pre-1990 environmental regulations), utilities have a wide variety of compliance choices available in Phase I and Phase II.

100 The environment externality adder issue within the context of utility integrated resource planning has received significant attention by the states and the DOE over the past five years. The debate over the appropriateness of the use and design of adders has been significant (see, for example, Krupnick et al. 1992).

101 We assume here that the expected penalties associated with violation of Title IV and Sections 107 and 108 of the CAA are greater than the expected costs of compliance.

102 Note that this assumes that market values are reflected in the regulatory treatment of the various compliance assumptions. Influences such as the A-J effect are assumed to be mitigated or decreased by proper rate treatment and competitive forces. 
The compliance planning process is essentially an integrated resource planning (IRP) process that, unlike the past, allows the utility significant flexibility in choosing its environwental compliance options for $\mathrm{SO}_{2}$. For utility compliance planning, only a slight alteration in the traditional IRP framework needs to be made, as illustrated in Figure 4.1. Instead of examining the universe of power generation options, the universe of $\mathrm{SO}_{2}$ compliance strategies (which may include many alternative power generation options) is examined. The screening criteria for the options are essentially similar to the screening criteria in the IRP setting. The central difference here is the associated environmental requirements.

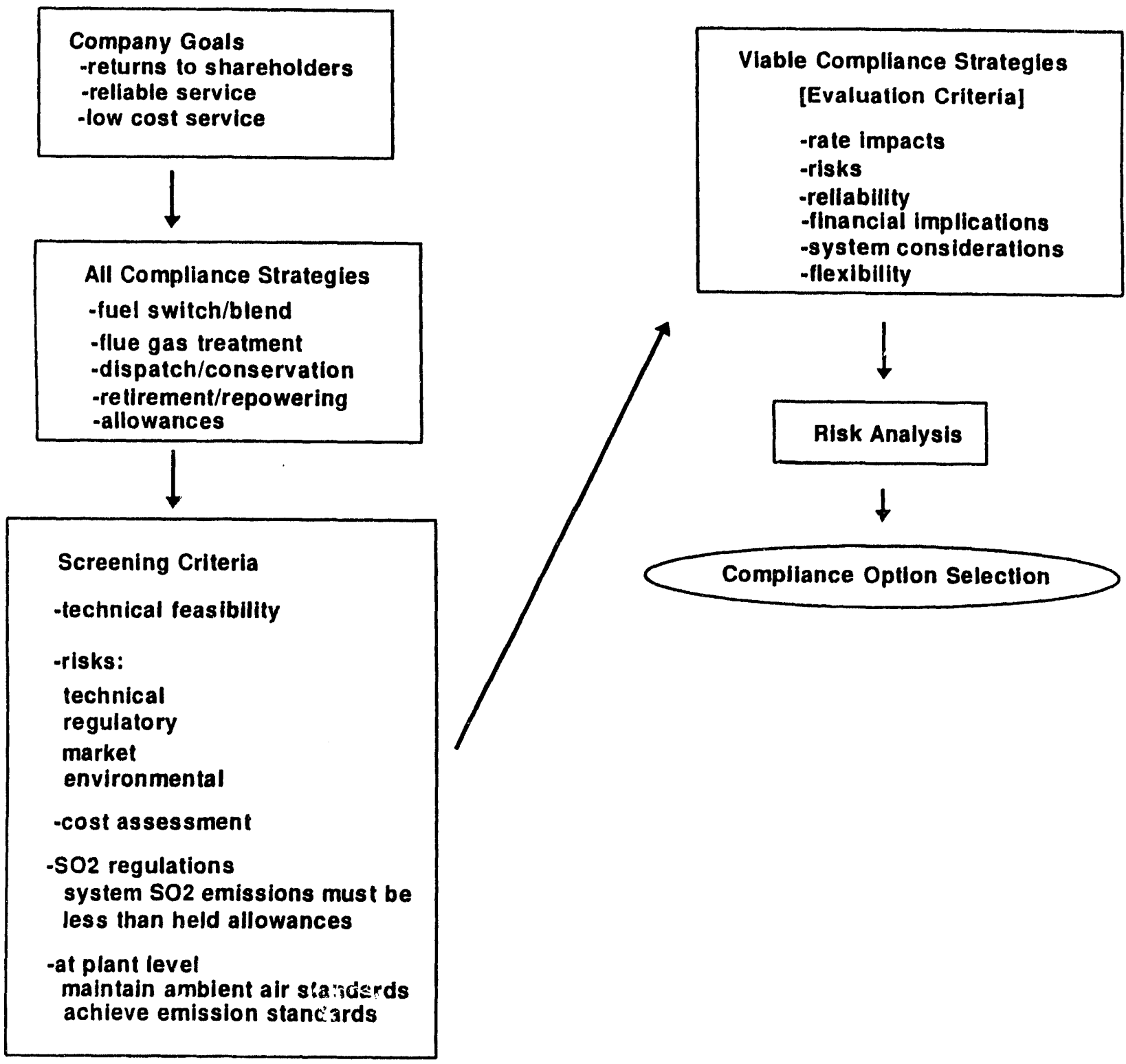

FIGURE 4.1 Utility Compliance Planning Process 
Of special note in the screening criteria is the examination of various categories of risk associated with each option. Technology risks refer to factors such as a firm's experience with a technology, lead times, retrofit ease, and, to a certain extent, flexibility of the option to alteration. Regulatory risks include those factors that may prevent full cost recovery of particular options. In addition, regulatory risk can include socioeconomic impacts of the policy on native load customers. Environmental risks address those concerns regarding compliance after the implementation of the option. These include flexibility to adapt to future regulation, permitting issues, and ability to meet current requirements. Market risks address cost and financial related impacts of compliance decisions. All risks and their subcomponents are weighted on the basis of concern to the firm. The assessment at this point is usually qualitative.

After screening, a set of viable compliance strategies emerges. For the IRP process, a set of viable supply-side and demand-side options would be indicated. At this point, the viable strategies are examined on the basis of rate impacts, flexibility, reliability, risk, financial integrity, and system considerations. Figure $\mathbf{4 . 2}$ illustrates the evaluation criteria and subcriteria. Finally, the chosen strategies undergo a quantitative risk analysis typically based on various scenarios of load growth, fuel price, and other factors. For the compliance planner, other factors could include imposition of additional environmental regulations and the like. The option or options that provide the most robust result in terms of expected benefits for lowest costs should be selected.

Existing and concurrent regulations for other criteria and multimedia pollutants (e.g., wastewater discharge and high-volume combustion waste) may both expand and limit the range of $\mathrm{SO}_{2}$ compliance options, as illustrated in Figure 4.3. Existing regulations under the CAAA for $\mathrm{NO}_{\mathrm{x}}$ and $\mathrm{PM}_{10}$ and consideration of water use and waste flows are of particular concern to the $\mathrm{SO}_{2}$ compliance planner. Compliance with existing and concurrent requirements can be thought of in several ways. First, in the case of concurrent regulations (e.g., Phase I units with wet bottom-fire boilers must be in compliance with Title IV NO and Title IV SO $\mathrm{S}_{2}$ on January 1,1995 ), the planner could choose a synergistic or cocontrol strategy. Synergistic compliance implies the use of a compliance option that reduces more than one of the regulated pollutants. If cost-effective, the synergistic option could be used to cocontrol the pollutant flow, which has been controlled separately in the past. Similar to compliance methods before the 1990 CAAA, the other strategy would be the use of separate controls for each pollutant (for example, low-sulfur coal for $\mathrm{SO}_{2}$ reduction, alternate firing arrangements for $\mathrm{NO}_{\mathrm{x}}$ reduction, and a baghouse or ESP for PM).

The choice set of compliance options is expanded by the inclusion of synergistic controls. The $\mathrm{SO}_{2}$ compliance choice set may be limited if that option results in an unacceptable emission level of another regulated pollutant or if it renders the cost-effective control strategy of the other regulated pollutant ineffective (i.e., the $\mathrm{SO}_{2}$ controls raise the costs of control for the other regulated pollutant to unacceptable levels). From the remaining set of pollution control options, the utility will choose separate or synergistic $\mathrm{SO}_{2}$ controls for each unit. 


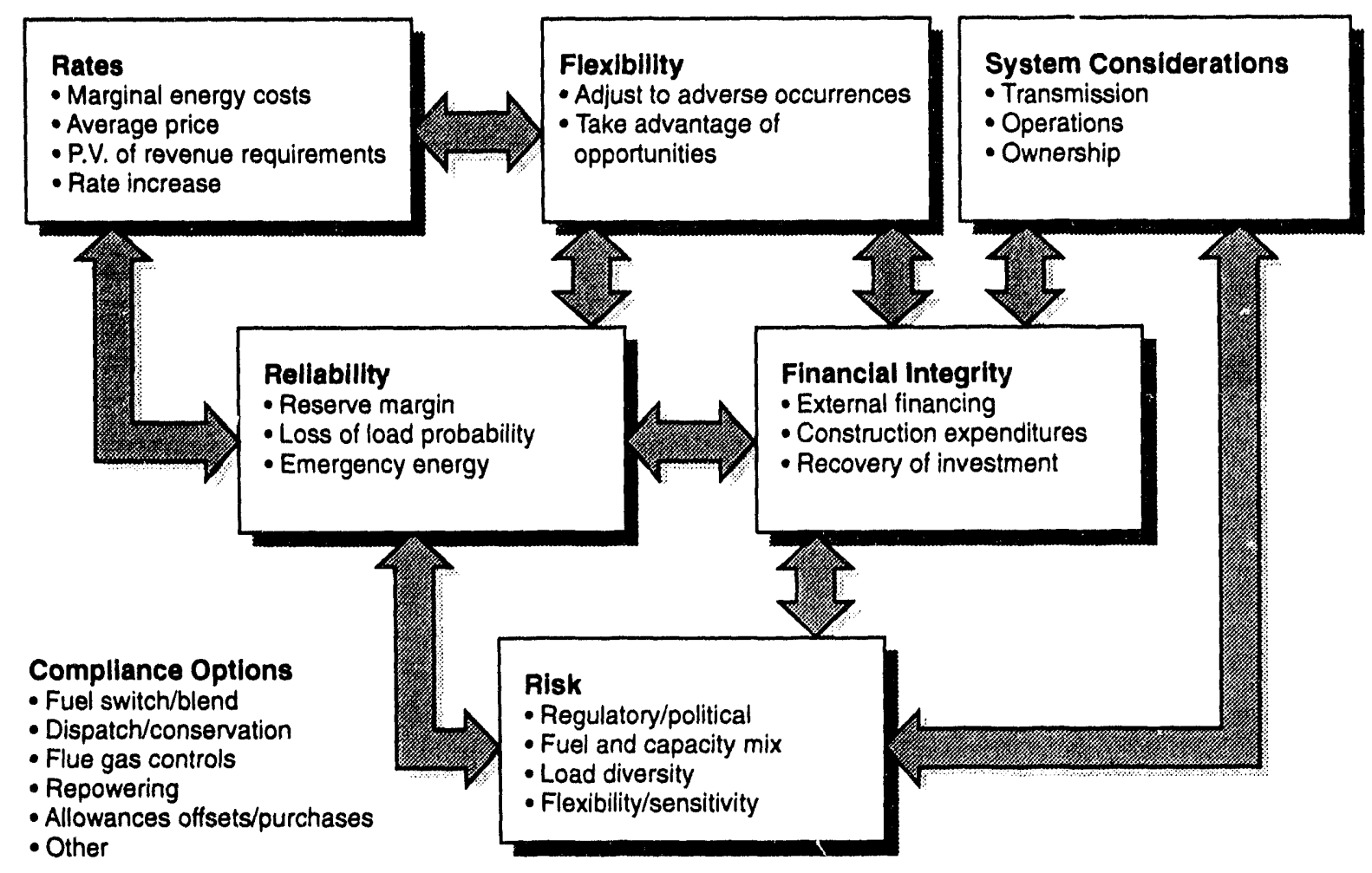

FIGURE 4.2 Set of Possible Evaluation Criteria (PV, present value). (All evaluation criteria are interlinked.)

An important issue associated with either control strategy is flexibility or the ability to alter control options under changing conditions. This concern is examined in both the screening stage and the development of the viable compliance plan stage of the compliance planning process. Understandably, the affected utility will attempt to choose the least-cost compliance plan for the present and in the future. Ideally, the firm would desire complete flexibility so the least-cost compliance option may be chosen period by period; however, some options tend to be capital-intensive or contractually limited so that month-by-month or annual changes in strategy are effectively impossible.

Price and demand fluctuations may lead to particular strategies becoming uneconomic relative to other strategies or may cause the regulatory pollution standards not to be met. Price fluctuations of fuel and allowances create both market and regulatory risks for the firm. If the firm chooses the higher cost option, its rates will tend to be greater (ceteris paribus), which may endanger its competitive position in wholesale power markets. Regulatory risk arises from the possibility of ex-post-prudence reviews denying the chosen option in rate base or cost pass-through due to other options having a relatively lower cost at present than the chosen option. Failure to meet an environmental constraint may mean fines or paying premium prices for $\mathrm{SO}_{2}$ allowances. 


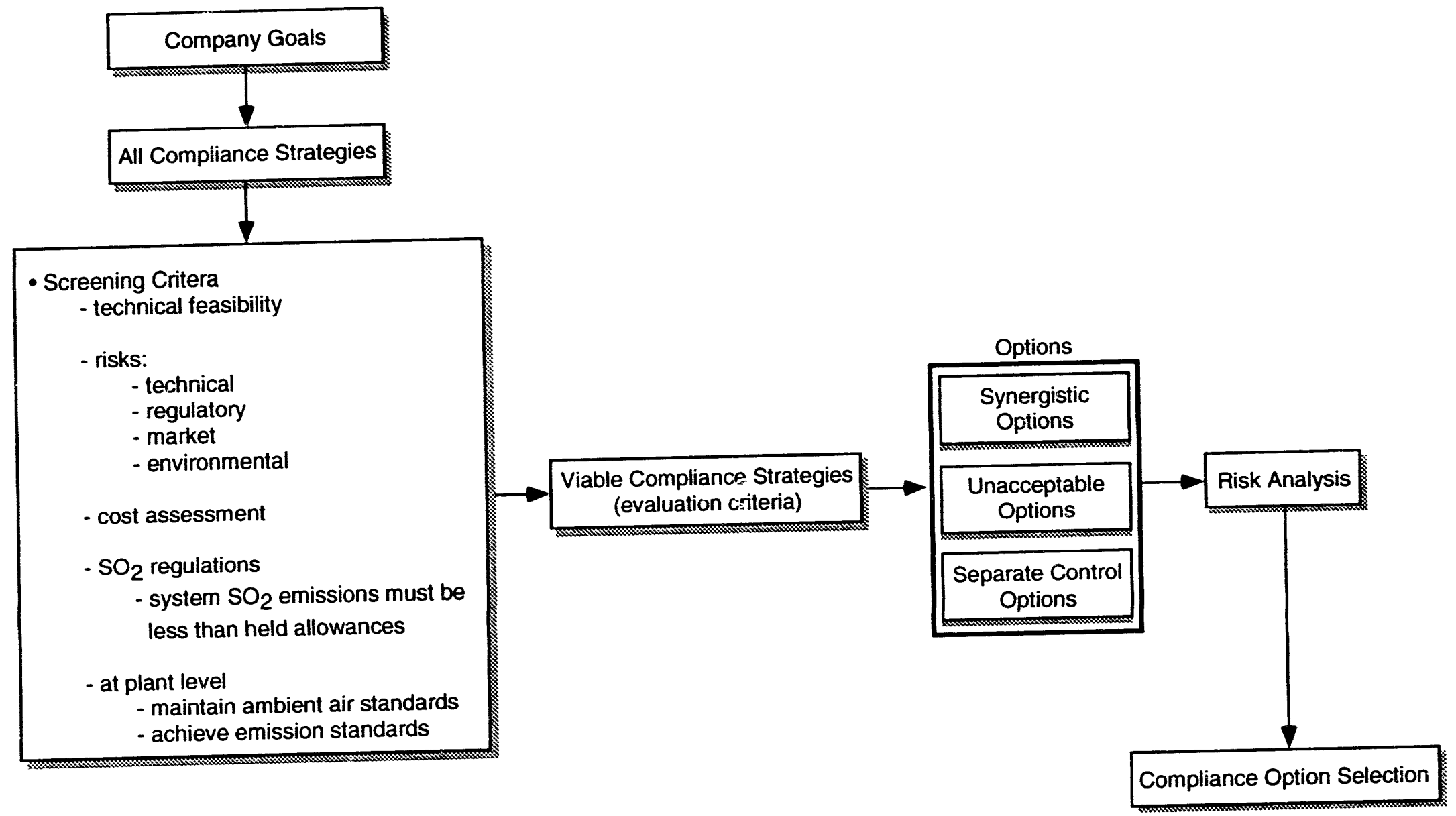

FIGURE 4.3 Compliance Planning under Concurrent or Existing Regulations 
As indicated in Section 1, specific regulation of $\mathrm{HAP}$ legislation controlling $\mathrm{CO}_{2}$ has not been issued. Environmental regulatory uncertainties have the potential to be an even greater challenge to the $\mathrm{SO}_{2}$ compliance planner. It is within a framework of price and demand uncertainty, combined with regulatory uncertainty, that the planner will operate. In this framework, the planner must still meet existing choice constraints while minimizing costs. Flexibility to alter plans from period to period is also required, although technical realties may prevent plan alterations within shorter time frames.

The set of compliance options to control $\mathrm{SO}_{2}$ will be expanded or limited based on the type, timing, and magnitude of controls for regulated pollutants. The type of pollutant regulated (or not regulated) will potentially make certain synergistic control options viable. ${ }^{103}$ Timing relates to compliance deadlines. Obviously, long compliance deadlines will allow firms to better assess both market conditions and appropriate response strategies. Timing of the regulations will also affect the cost-effectiveness of certain options. ${ }^{104}$ The magnitude of the controls will determine if the pollutant can be successfully controlled through small modifications or addicions to existing systems or if wholesale alteration of existing systems is required. With perfect foresight, the planner would be able to take advantage of cost-effective control if synergies were possible. The time line for Phase I and II planning, combined with future and potential regulatory rulings, is illustrated in Figure 4.4.

In the presence of environmental regulatory uncertainty, the planner may choose a synergistic control strategy for the unregulated pollutant or adopt an incremental or sequential compliance strategy and control pollutants as they are regulated. Both approaches have their associated costs and benefits. Figure 4.5 generally illustrates the issue of compliance option choice for a Phase I unit, given environmental regulatory uncertainties. For the Phase II unit, the environmental risks decrease dramatically. For these units, the full range of planning synergies is available because of the decrease in regulatory and environmental risks; therefore, these units can choose their compliance strategies based on least cost. ${ }^{105}$

103 If a pollutant is not regulated, no synergistic control option to cocontrol that pollutant is needed.

104 For example, a utility installs a scrubber in order to remove $\mathrm{SO}_{2}$. The scrubber decision is based on expected low-sulfur fuel prices and the like. Given the scrubber tends to be $15-25 \%$ of the cost of a new unit, this is a large and relatively inflexible investment. Even if not used, the utility and ratepayers will pay for the scrubber. Then, assume that $\mathrm{CO}_{2}$ controls are mandated after the scrubber is installed. The longer the time to plan for the $\mathrm{CO}_{2}$ emission reduction through alternative means (DSM, reduced utilization, or altered dispatch order) and proper time to depreciate the scrubber, the better off the utility will be, as radical measures do not need to be taken to dramatically reduce $\mathrm{CO}_{2}$ immediately. If the planning horizon was reduced, shareholders and ratepayers could incur higher losses.

105 Note that this assumes that no post-Phase II-issued environmental regulations pose serious risks to compliance options chosen in Phase II (in terms of market, environmental, regulatory, and technical risks). It should be stressed that Phase I affected units are also Phase II affected units, and a potentially high-cost undertaking may be required to correct for inappropriate Phase I choices in order to meet Phase II needs and other compliance requirements. 


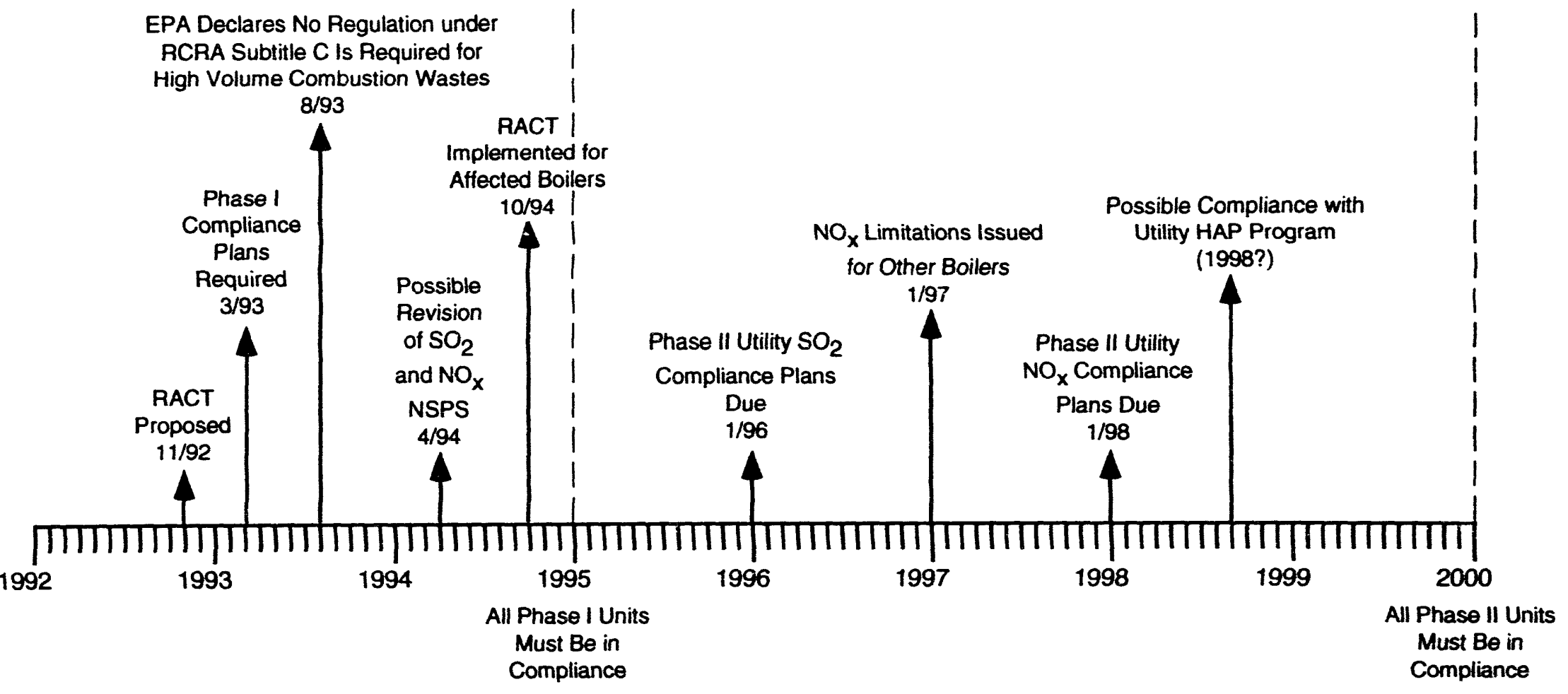

FIGURE 4.4 Synergies and Compliance Planning 


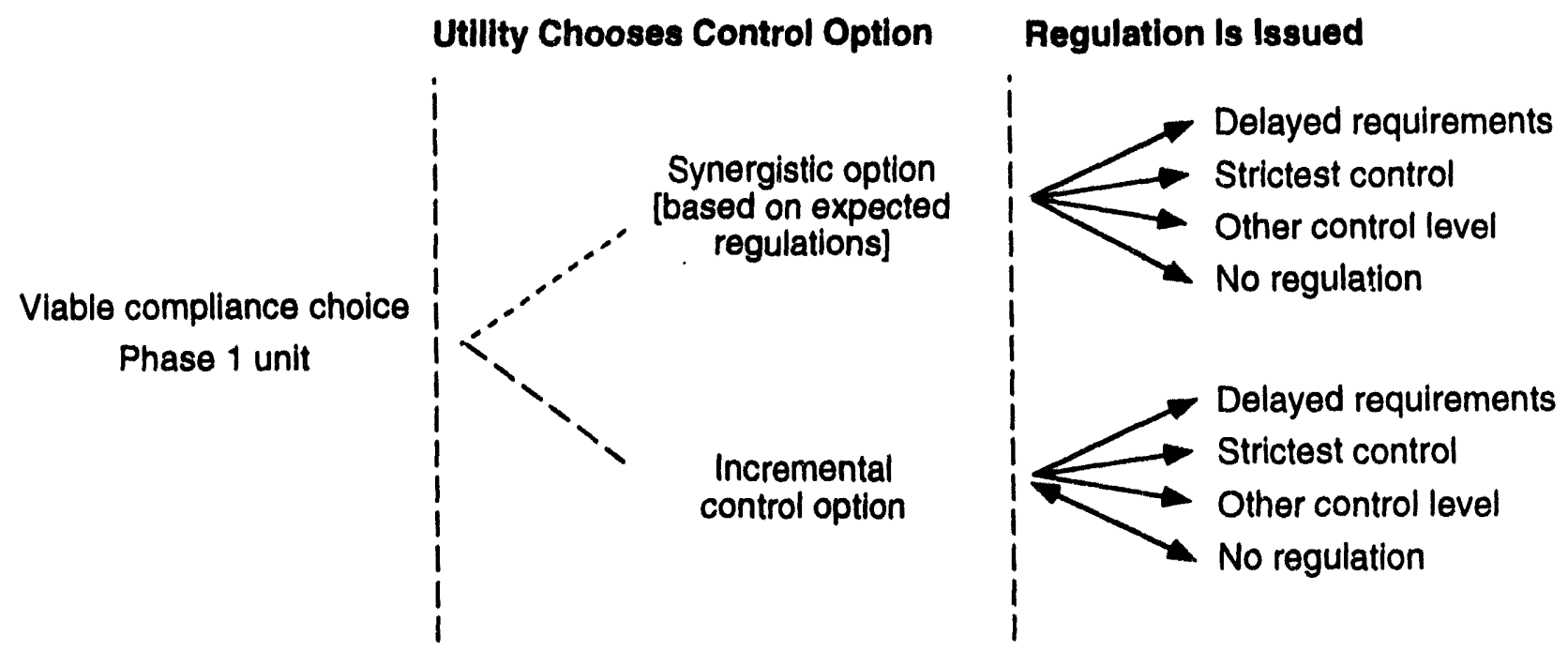

FIGURE 4.5 Phase I Compliance Selection and Ramifications

The synergistic control strategy will choose an option that cocontrols $\mathrm{SO}_{2}$ (possibly along with controlling already regulated pollutants) and pollutants expected to be regulated in the future. The benefits are cost-effective control of both pollutants, ${ }^{106}$ possible capitalization on an early reduction program's benefits, ${ }^{107}$ and lengthening the planning cycle. ${ }^{108}$ The central drawback to this approach occurs if the pollutant in question is not regulated or if an improved option is available before compliance is required. Under rate regulation, an expenditure must be judged "used and useful" before it may be entered into rate base. Two problems emerge: (1) Does precontrol justify inclusion in rate base? (2) If the pollutant is not regulated, part of the cost of control will be denied. If the synergistic option is more expensive than an alternative option - and its justification is early, cost-effective synergistic control - part of the investment may not be allowed in rate base (if a capital expenditure). The utility has a disincentive to invest in an option from which it will receive only partial benefits in the near term and may be penalized in the future.

Incremental control avoids the risks associated with cocontrolling pollutants that may not be regulated in the future. The chief benefit of the incremental control approach would be the expected cost savings in the present; however, if the pollutant is regulated in the future, the synergistic option may have been the least-cost choice, instead of applying separate controls for each pollutant.

106 Assuming the costs of the synergistic option are less than the combined cost of separately controlling each option.

107 The air toxics program includes an early reduction program, Section 112(i)(5).

108 The "bugs" in controlling the pollutant may be corrected; lower prices and greater technology options may be available. 
The issue of flexibility becomes important in each control strategy. With either strategy, copollutants of an unacceptable future level may be generated, although the synergistic option, by definition, attempts to reduce the emissions of uncertain future pollutants. The incremental option runs a greater risk of generating unacceptable copollutants, which may be difficult to control, or the initial option may be difficult to alter. Michael Shapiro of the EPA was asked at a recent EPRI conference the following question: "If utilities' efforts to reduce $\mathrm{SO}_{2}$ result in increases in utilities' emissions of air toxics, can EPA assure utilities that EPA will not come back and ask utilities to reverse their prior investments?" Shapiro gave the answer one would expect, and which is probably legally correct. He answered that the CAAA do not allow him to give those guarantees. ${ }^{109}$ If an incremental option lacks flexibility to alter or integrate with future pollutants, it will mean higher costs of compliance.

In principle, the object of utility compliance planning is to coordinate the programs so that no control investments are duplicated or wasted; however, the stair-step approach creates both inefficiency and uncertainty problems. Taken together, the stair-step method constructs a piecemeal approach to utility regulation, with partial steps being taken one at a time, preventing coordination and planning. The poor integration of the Act will likely result in incremental and isolated compliance strategies and suboptimal decisions by utilities.

Underlying these planning dilemmas is a temporal mismatch of the various titles. The Act is structured into a stair-step approach of incremental phases. It therefore places electric utilities in jeopardy of "creeping incrementalism" by regulation. What is absent from the Act is the opportunity for electric utilities to act according to their needs within rate regulation. The absence of the opportunity to coordinate the various CAAA programs, in combination with the statutory structure and the uncertainty of the utility exemption, could make Title IV far more costly than a coordinated program.

Market-based mechanisms such as the $\mathrm{SO}_{2}$ program offer some remedies to the compliance choice problem. Intraplant trading of $\mathrm{NO}_{x}$ emission taxes and other trading may offer methods of reducing the planning difficulties with lower costs, compared with having to choose technical compliance options. Allowance banking provides a means of avoiding installation of expensive options at present. The option value gained by waiting could make the difference between cost-effective compliance and ex-post-rejection of the control option in a rate case. The flexibility from market mechanisms can alsu hedge risk through mixing compliance strategies across units in a firm.

109 Remarks during question-and-answer session at EPRI air toxics conference, November 1991. 


\subsection{IMPACT OF REGULATORY CONTROLS ON $\mathrm{SO}_{2}$ COMPLIANCE}

\subsubsection{Interaction of Title IV with Title I-NO}

Two programs of the $1990 \mathrm{CAAA}$ are targeted at reducing $\mathrm{NO}_{\mathrm{x}}$ emissions. Section 407 of the Title IV program requires all coal-fired boilers that are affected under the $\mathrm{SO}_{2}$ program to reduce $\mathrm{NO}_{\mathrm{x}}$ emissions. Emission controls are mandated on a unit basis to control $\mathrm{NO}_{x}$ as a precursor to acidic deposition. The Title I program requires states to specify $\mathrm{NO}_{\mathrm{x}}$ RACT controls for utility fossil-fuel boilers as part of the revised SIP. The Title I program mandates retrofit emission controls on a unit basis to control $\mathrm{NO}_{\mathrm{x}}$ as a precursor to tropospheric $\mathrm{O}_{3}$ formation.

While the Title IV control requirements apply to all units of a certain class (i.e., coal units affected under Phases I and II), Title I requirements are site-dependent. The impacts of the RACT requirements are site-specific, depending on the $\mathrm{O}_{3}$ air quality status of the area. The RACT control levels proposed by the EPA and several states also differ. Both the severity of the $\mathrm{O}_{3}$ nonattainment problem and alternative specifications of what constitutes a reasonably available control technology (RACT) have led to the differences in emission limits.

For Title IV, proposals to define the $\mathrm{NO}_{\mathrm{x}}$ control strategy were issued; and for Title I, the EPA-proposed RACT emission standards were recently issued. ${ }^{110}$ In both cases, the late issuance has created difficulties. By February 15, 1992, utilities were required to submit Phase I compliance plans. Given the planning and capital investment required for any new pollution control option, the delay in the definition of low-NO $\mathrm{N}_{\mathrm{x}}$ burner technology may perturb the planning process. The EPA's suggested RACT standards were issued in the Federal Register of November 25, 1992; however, the states were required to submit their SIPs to the EPA by November 15, 1992. The late timing of the EPA's RACT proposal has created difficulties for states in meeting the required plan deadlines.

Section 407 mandates $\mathrm{NO}_{\mathrm{x}}$ emission limits for dry bottom wall-fired boilers and tangentially fired boilers. All Phase I units with these boiler types must be in compliance by January 1,1995 . Because of the joint compliance deadlines with $\mathrm{SO}_{2}$, utilities may plan their strategies concurrently. The EPA is to issue $\mathrm{NO}_{x}$ emission standards for wet bottom wall-fired boilers, cyclone boilers, and all units applying cell burner technology by 1997.

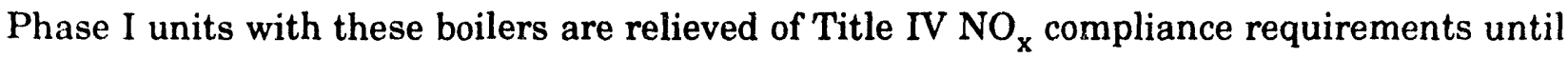
the regulations are issued. The delayed $\mathrm{NO}_{\mathrm{x}}$ compliance for these units may cause some planning difficulties. If, in 1997, the unregulated boilers receive very strict control levels and the existing regulated boilers under Phase $I$ are given stricter control levels, certain previously chosen $\mathrm{SO}_{2}$ control options may not be optimal from a synergistic control

11057 (No. 228) Fed.Reg. 55620 (Nov. 25, 1992) and 57 (No. 228) Fed.Reg. 55632 (Nov. 15, 1992). 
perspective ${ }^{111}$ If the later Title IV NO ${ }_{x}$ standards follow the strictness of the EPA's proposed RACT controls, there should be relatively few difficulties associated with $\mathrm{NO}_{\mathbf{x}}$ control conditional on already established $\mathrm{SO}_{2}$ controls.

Phase II units will be required to jointly comply with both the $\mathrm{SO}_{2}$ and $\mathrm{NO}_{\mathrm{x}}$ programs of Title IV on January 1, 2000. Because the standards for all coal-fired boilers (including revisions from previous control levels) must be in place by 1997, utilities can coplan their strategies for Phase II.

Those units in nonattainment areas and $\mathrm{O}_{3}$ transportation regions are required to meet RACT standards. The EPA's Title I RACT standards are identical to Title IV's $\mathrm{NO}_{\mathrm{x}}$ emission standard for tangentially fired and dry bottom wall-fired boilers. All units affected under Title I must be in compliance by May 31, 1995. Unlike Title IV, which separates affected units into two phases and delays regulation of wet bottom wall-fired boilers, cyclone boilers, and units applying cell burner technology until after Phase I begins, all boiler types must meet emission standards by May 31, 1995.

Phase I units affected by Title I will tend to face identical control requirements, given the EPA's proposed RACT limitations; however, those units in areas where $\mathrm{O}_{3}$ nonattainment is a severe problem may be required to control $\mathrm{NO}_{\mathrm{x}}$ to greater levels. Given the coincidence of both programs' timing, one would expect fewer difficulties. Phase II units affected under Title I will be required to implement $\mathrm{NO}_{\mathbf{x}}$ control strategies well before any $\mathrm{SO}_{2}$ reduction is needed.

In areas where $\mathrm{O}_{3}$ nonattainment is persistent, even after a first round of controls, another "phase" of stricter controls may be needed. NESCAUM has suggested that $\mathrm{NO}_{\mathrm{x}}$ emission levels equivalent to those achieved by advanced overfire air, selective catalytic, or noncatalytic reduction processes be implemented for those units in areas unlikely to meet required attainment dates. The second phase of the RACT requirements would presumably occur before 2000 (STAPPA-ALAPCO 1992). For many jointly affected units, the stricter requirements would imply altering controls installed for January 1995 compliance. Unlike the Title IV $\mathrm{NO}_{\mathrm{x}}$ control program, in which Phase I and Phase II units can comply concurrently with $\mathrm{NO}_{\mathrm{x}}$ requirements, units also affected by RACT could face retrnfit requirements and conflicts with the existing $\mathrm{SO}_{2}$ control technology.

A range of synergistic and incremental control options is available to comply with the three programs (Title IV-SO ${ }_{2}$, Title IV-NO ${ }_{x}$, and Title I-NO ${ }_{x}$ ). With the exception of possibly tightening standards in a "Phase II" of Title I for a select group of boilers, utilities may take advantage of synergistic strategies without being exposed to large regulatory and environmental risks.

111 In essence, the lower cost control option would have jointly controlled both pollutants, rather than separate controls being used for each pollutant or an $\mathrm{SO}_{2}$ option altered later to control $\mathrm{NO}_{\mathrm{x}}$ emissions. 
Only one synergistic option combines $\mathrm{SO}_{2}$ and $\mathrm{NO}_{\mathrm{x}}$ reduction through flue gas cleanup. Limestone-injection multistage burners offer $40-70 \%$ reduction of both pollutants; however, commercialization of this technology is estimated to be four to five years away, and the method is applicable to less than $3 \%$ of the coal-fired utility boiler population (South et al. 1990). Other effective synergistic options are through boiler repowering/ greenfield and reduced utilization/conservation. Fluidized-bed combustion and IGCC options are estimated to achieve greater than $90 \% \mathrm{SO}_{2}$ emission reductions and $40-95 \% \mathrm{NO}_{\mathrm{x}}$ emission reductions. These options will most likely be implemented as part of Phase II because of the precommercial status of these technologies and significant timing and capital requirements. Reduced utilization, altered dispatch order, and conservation also can reduce both pollutants through substituting cleaner generation (or nongeneration with conservation) for higher emission units. Power purchases and the transfer of generation from areas without nonattainment difficulties may provide a useful and cost-effective means of meeting regulatory requirements. Finally, fuel switching options such as switching from high-sulfur midwestern coals to low-sulfur western coals and natural gas cofiring will reduce emissions of $\mathrm{SO}_{2}$ and $\mathrm{NO}_{\mathrm{x}}$. Coal blending and switching will have some impacts on $\mathrm{NO}_{\mathrm{x}}$ emissions, as Powder River basin coal tends to produce 30\% less $\mathrm{NO}_{x}$ than high-sulfur midwestern coals (Watson 1992). Natural gas cofiring can reduce $\mathrm{NO}_{\mathrm{x}}$ emission by $50-70 \%$ (South et al. 1990).

Many of the $\mathrm{SO}_{2}$ compliance options for conventional pulverized coal boilers will not prevent or unduly restrict the application of separate $\mathrm{NO}_{x}$-reducing technologies. Incremental $\mathrm{NO}_{\mathrm{x}}$ control strategies can be divided into two categories: (1) combustion modifications, and (2) postcombusti difications. Combustion modifications entail altering the fuel and air mixes and fi perature during coal (or other fuel) combustion. These technologies include low- $\mathrm{NO}_{\mathbf{x}}$ bu . overfire air, and alternated firing arrangements. Postcombustion modifications tend to be add-ons that treat flue gas after combustion. These technologies include selective catalytic and noncatalytic reduction controls.

While many Phase I and Phase II units will be able to coplan their $\mathrm{SO}_{2}$ and $\mathrm{NO}_{\mathbf{x}}$ control strategies, the issue of dramaicically tighter RACT requirements in a "Phase II" of Title I could present some risks. The limitations for Phase II of Title I would imply the use of postcombustion modifications (which at present are considered precommercial technologies [South et al. 1990]) and/or alteration of fuel use. Technical difficulties do not seem to be the central problem, but instead added costs pose a major problem.

Some added costs and control requirements may be reduced with plantwide emission averaging. The $\mathrm{NO}_{\mathrm{x}}$ program does not offer utilities the ability to engage in portfolio compliance for $\mathrm{NO}_{\mathrm{x}}$ on a systemwide basis, but units within a plant have emission averaging options available under Title I and Title IV. ${ }^{112}$ Emissions averaging allows affected units to choose emissions controls based on the relative control costs between the units. Another program that has received discussion is the trading of $\mathrm{NO}_{\mathrm{x}}$ offsets on a regional basis. ${ }^{113}$

112 Sections 172(c)(6) and Section 5.4 of 57 Fed.Reg. No. 228 (Nov. 25, 1992).

113 Fed.Reg. supra. 
Sources reducing $\mathrm{NO}_{\mathrm{x}}$ below a predetermined level receive credits that may be sold to other sources within the region. The final ruling on the trading of $\mathrm{NO}_{\mathrm{x}}$ in the NESCAUM area has not been issued. The Texas Air Control Board has issued proposed regulations covering the trading of $\mathrm{NO}_{\mathrm{x}}$ offsets within the Houston-Galveston and Beaumont-Port Arthur areas. ${ }^{114}$

\subsubsection{Interaction of Title IV-SO ${ }_{2}$ with Title III}

Several major utilities have claimed that toxic emissions from electric utilities do not pose a problem because

1. Utilities emit only two types of air toxics - trace metals as particulates and $\mathrm{Hg}$.

2. Air toxics as particulates are cocontrolled through existing particulate (PM ${ }_{10}$ ) controls (i.e., ESPs and baghouse); and by Phase II of Title IV, $\mathrm{SO}_{2}$ control measures will be installed (i.e., FGD and boiler repowering), which also cocontrol emissions of $\mathrm{Hg}$.

Both of these claims are subject to question. First, are trace metals as particulates and $\mathrm{Hg}$ the only sources of HAP emissions from utility units? Second, will a majority of units adopt synergistic controls that reduce $\mathrm{SO}_{2}$ and $\mathrm{Hg}$ so that the residual levels are inconsequential? Third, could emissions of some air toxics actually increase because of Phase I compliance actions? The role of synergies and copollutants in the interactions of Title III and Title IV are important in examining these questions.

The Title III study of HAP emissions from electric utilities was to be completed by November 1993 but, from indications, probably will not be completed until 1995..$^{115}$ Thus, it is unlikely that the EPA will propose emission standards for electric utilities any sooner than 1995, and given the history of MACT rule-makings, the agency will not likely publish a final rule until one year hence, 1996, at the earliest.

By the time when the EPA's Title III intentions are known, Phase I affected units will be committed to (if not having already implemented) $\mathrm{SO}_{2}$ compliance strategies. Because of the lag in the issuance (or nonissuance) of utility HAP regulation, affected utilities face greater environmental, regulatory, technical, and market risks. As illustrated in Figure 4.6, the Phase I affected utility has a choice of synergistic (based on the HAP expected to be regulated) and incremental control options. If $\mathrm{Hg}$ is taken as an example, synergistic control options that would reduce $\mathrm{SO}_{2}$ and $\mathrm{Hg}$ include blending with or switching to coals with lower

114 Texas Register, June 1992.

115 As indicated earlier, the Section 112(n)(1) studies of utility HAPs and the NIEHS study of Hg thresholds were due in November 1993; the study of $\mathrm{Hg}$ emissions is not due until November 1994 but has since been delayed for issuance in 1995 . 


\begin{tabular}{|c|c|c|}
\hline Control Approach & $\begin{array}{l}\text { Possible } \\
\text { Regulatory Outcomes }\end{array}$ & Economic Consequences \\
\hline \multirow{3}{*}{$\begin{array}{l}\text { Synergistic } \\
\text { Phase I - } \mathrm{SO}_{2} \\
\text { Phase I - } \mathrm{NO}_{\mathrm{X}} \\
\text { RACT NO} \\
\text { HAP(s) }\end{array}$} & \multirow{3}{*}{$\begin{array}{l}\text { Delayed } \\
\text { Requirements } \\
\text { MACT or Other } \\
\text { Requirement } \\
\text { No Requirement }\end{array}$} & $\begin{array}{l}\text { - Delay of expenditures in rates } \\
\text { - Potential approval consequences }\end{array}$ \\
\hline & & $\begin{array}{l}\text { - Cost reducing/"win" outcome } \\
\text { - Possible over-control credit } \\
\text { - Possible partial denial }\end{array}$ \\
\hline & & - Denial of added spending in rates \\
\hline \multirow{4}{*}{$\begin{array}{l}\text { Discrete } \\
\text { Phase I - } \mathrm{SO}_{2} \\
\text { Phase I- } \mathrm{NO}_{\mathrm{X}} \\
\text { RACT NO} \\
\text { RA }\end{array}$} & \multirow{4}{*}{$\begin{array}{l}\text { Delayed } \\
\text { Requirements } \\
\text { MACT or Other } \\
\text { Requirement } \\
\text { No Requirement }\end{array}$} & $\begin{array}{l}\text { - Saved costs on early control } \\
\text { - Possible prevention of least cost choice }\end{array}$ \\
\hline & & $\begin{array}{l}\text { - Possible conflicting controls } \\
\text { - Possible greater compliance costs }\end{array}$ \\
\hline & & • "Win" strategy \\
\hline & & - No excess costs incurred \\
\hline
\end{tabular}

FIGURE 4.6 Title IV Phase I Compliance and Possible Title III Regulatory Outcomes

Hg and sulfur contents, wet FGD, reduced utilization/altered dispatch, conservation, natural gas cofiring, and boiler repowering. Incremental options (which do not address $\mathrm{Hg}$ control) include fuel switching or blending with Appalachian compliance and medium-sulfur coals, fuel switching or blending with lower sulfur midwestern coals, and the use of allowances for compliance requirements. Assume that there are four possible outcomes associated with the regulation of $\mathrm{Hg}$. These are (1) regulation of HAP is delayed until Phase II, (2) MACT is required for utility boilers before Phase II, (3) a lesser standard for $\mathrm{Hg}$ is required before Phase II, and (4) no regulation of $\mathrm{Hg}$ emissions is required.

If synergistic control was chosen, the level of $\mathrm{Hg}$ control, combined with the control costs, becomes important. Obviously, if no regulation is required, the utility may face regulatory denial of at least part of the synergistic option, and market risks rise as compliance costs increase. Note that certain options involving conservation, altered utilization, and possibly natural gas cofiring will face lower risks due to lower costs (except natural gas) and other positive rate and environmental effects. If regulation is instituted for $\mathrm{Hg}$, the synergistic option faces the risk of not controlling emissions to the standard's level (which would necessitate greater control measures), although some benefits may be gained by early reduction. The effect of delay for the synergistic option is uncertain. One factor that should be emphasized is the "used-and-useful" doctrine. If the synergistic option cannot be justified by system cost savings or integrity benefits, it may be partially denied in rate base. 
The incremental option faces the same set of possible regulatory outcomes; however, certain options in its choice set will increase $\mathrm{Hg}$ emissions (i.e., increased use of Appalachian coals). If no control of $\mathrm{Hg}$ emissions is specified, the utility has chosen the least-cost strategy (ceteris paribus). Regulation of $\mathrm{Hg}$ delayed to Phase II may also be beneficial to the incremental strategy. As the unit would be required to alter control options by the beginning of Phase II, temporary strategies that were not exceptionally costly would be optimal; ${ }^{116}$ however, if MACT or another standard for $\mathrm{Hg}$ is required in Phase I, the optimal strategy may have been (depending on the timing of the new regulations and Phase I compliance costs) to choose the synergistic option. In this case, the firm may face regulatory and potential market penalties because of its incremental strategy.

Phase II affected sources may face Title III requirements before their Title IV compliance requirements. Given that the EPA will not likely issue a final rule on electric utility MACT until 1995 at the earliest, that rule would then become effective three years hence, or 1998. A 1998 date will allow the affected units to coplan their Title IV and Title III compliance strategies; but if the Title III standard is delayed any significant time beyond 1998 or if Title IV Phase II electric utilities take early actions to comply with Phase II that would also reduce air toxics emissions sufficiently, Phase II units may face the same difficulties as their Phase I counterparts. Since Phase I units face a second round of $\mathrm{SO}_{2}$ reductions in Phase II, they also could coordinate control strategies to achieve Phase II reductions with MACT.

There is a wide range of synergistic control options available to the reduction of several HAPs. A general observation regarding available air toxics control options is that many of the options to reduce particulate or $\mathrm{SO}_{2}$ emissions also reduce many of the air toxics. Fewer control options are available at present to control HAP emissions alone.

Flue gas treatment technologies such as FGD have important $\mathrm{HAP}-\mathrm{SO}_{2}$ control synergies. With the notable exception of $\mathrm{Hg}$ emissions, which occur as a gas under high temperatures, most trace metal emissions from coal-fired utilities are either absorbed onto the fly ash or precipitate with the bottom ash. Trace metal emissions absorbed onto the fly ash can be controlled by particulate control technologies, such as baghouses and ESPs. Mercury emissions are able to be effectively removed with wet scrubber controls. Mercury emissions can also be reduced if a utility selects low- $\mathrm{NO}_{\mathrm{x}}$ burners. Combustion temperatures are lowered, and $\mathrm{Hg}$ is absorbed in the fly ash, which can be effectively controlled with particulate controls. In situations where a utility takes no steps to reduce combustion or flue gas temperatures, $\mathrm{Hg}$ could escape as a gas and require wet scrubber controls (Molburg et al. 1991).

116 In essence, a firm could choose to pay $\$ 100$ million today to meet present requirements and then pay $\$ 300$ million five years later to meet the next phase's requirements; or the firm could choose to pay $\$ 300$ million today to meet present and future requirements. Assuming no other benefits from the high-cost compliance, the least-cost choice will depend on the time value of money (or discount rate). With a higher discount rate, the first option would tend to be preferred. 
Fuel switching/blending between coals and with other fuels will have differing effects on copollutants and synergies. There is a trade-off between Title IV and Title III in coal fuel switching and blending. To the extent that utilities reduce sulfur emissions by switching from high-sulfur eastern coal to low-sulfur western coal, they increase the chlorine content of the coal. During combustion, the chlorine becomes $\mathrm{Cl}_{2}$ or $\mathrm{HCl}$, which corrodes the steel pipes of the unit and is then emitted. Hydrogen chloride is possibly already the largest single pollutant emitted from power plants. Moreover, there is some indication that other toxic particulates may result from combustion, and these particulates would be fine particles that enter deepest into the lungs (Laudal et al. 1991). In addition, coals vary by trace metal contents. Fuel switching or blending may reduce $\mathrm{SO}_{2}$ emissions, but without the presence of a wet scrubber or low- $\mathrm{NO}_{\mathbf{x}}$ burner, toxic metal emissions may grow.

In general, Title III will likely force utilities away from coal and toward other fuels that contain lower levels of trace metal air toxics. Coals like those in the Appalachian basin, which are enriched in sulfur and trace metals, especially $\mathrm{Hg}$, would be discouraged by both titles. Also, although a particular coal source may be selected for low sulfur content to meet Title IV, it may be enriched in trace metals, compared to other sources of coal, and be less acceptable for Title III purposes.

Natural gas, because of its minimal sulfur content, has a competitive advantage for Title IV compliance relative to other fuels. To the extent that totally natural gas-fired units' organic HAP emissions exceed the 25-ton/yr threshold or some lower threshold determined by the EPA, natural gas units may face the same Title III compliance requirements as units fired with other fuels. Thus, the advantage natural gas has for Title IV may be lost to Title III controls of organic HAPs. Trace metals are present in extremely small quantities with natural gas, and natural gas cofiring may be an effective strategy for the removal of these compounds.

Given the available control strategies and present regulatory environment, are utility HAP emissions a relatively small concern because of existing synergistic control strategies and the potential for even greater (perhaps unintentional) synergistic control in Phase II? To answer this question, one must first examine the HAPs of particular concern. While particulate controls reduce trace metal emissions and while wet limestone scrubbers reduce $\mathrm{Hg}$, organic HAPs and, in particular, chlorine may not be cocontrolled through these methods. Second, the expected low cost of Powder River basin coal well into the next century makes this coal an ideal compliance option for many utility units. One cannot assume that a majority of the Phase II population of units will scrub or otherwise repower to reduce HAPs to inconsequential levels.

\subsubsection{Interaction of Title $\mathrm{IV}-\mathrm{SO}_{2}$ with the Regulation of High-Volume Combustion Waste}

The problem of multimedia pollutant control has long been recognized as an environmental problem. In many processes, there exists the ability to reduce the effluent from one media (e.g., air) and transfer it into another unregulated or less strictly regulated 
medium. The uncontrolled combustion of coal produces air and solid wastes. Several $\mathrm{SO}_{2}$ control options generate significant levels of high-volume combustion wastes. The high-volume combustion wastes require disposal in the form of landfilling or sludge ponds or as a usable by-product. The final treatment of high-volume combustion wastes has both site-specific and systemwide implications. Site specificity comes from the relatively high costs of shipping wastes to faraway disposal sites and available on-site disposal areas. From a system perspective, dispatch and generation can be altered to reduce overall waste production.

Effective, large-level reduction of existing high-volume combustion waste streams through synergistic controls tends to be limited. Conservation, reduced utilization, and altered dispatch are synergistic means of reducing a unit's waste stream, but on a systemwide level, the effect is unlikely to be large. Repowering, retrofitting, or greenfield applications may be able to significantly reduce unit waste streams. Several technologies entering commercialization, including some dry FGDs, fluidized-bed boilers, and IGCC, are able to reduce nonuseful waste streams and provide useful by-products such as gypsum and elemental sulfur (South et al. 1990). Natural gas cofiring also can significantly reduce combustion wastes, depending on the level of cofiring.

Many of the flue gas treatment processes and, to a certain extent, fuel switching or blending with coals producing high bottom and fly ash contents generate greater levels of high-volume wastes. Scrubbing options will tend to be less economic because of landfill disposal costs and the need for additional sludge treatment ponds. Some types of coal fuel switching will become less economic based on the amount of ash and slag generated. In order to mitigate some disposal costs, several utilities have turned toward the commercial use of wastes as roadfill, concrete additives, and fertilizers.

\subsubsection{Interaction of Title IV-SO $\mathrm{S}_{2}$ with Greenhouse Gas Regulations}

Along with possible regulation of utility HAPs, regulation of $\mathrm{CO}_{2}$ emissions is seen as an issue that could greatly increase compliance costs; and unlike HAPs, existing and many planned acid rain controls (with the one exception of conservation) are unlikely to produce any control synergies.

Given present scientific uncertainties, along with concerns over the federal deficit and talk of energy taxes, the possibility of widespread carbon taxes or other means of $\mathrm{CO}_{2}$ reduction is uncertain in timing, type, and magnitude. Recent attendees of an EPRI acid rain conference indicated that the issue of $\mathrm{CO}_{2}$ regulation is equivalent to concerns regarding the regulation of HAPs. ${ }^{117}$ The inpact of the uncertainty on present utility $\mathrm{SO}_{2}$ compliance planning is unknown at present. Compliance planning under these conditions exposes the firm to market, financial, regulatory, and environmental risks in a manner similar to HAPs.

117 EPRI air toxics conference, 1991 (November). 
We can consider two classes of strategies when examining synergistic options and copollutants as they relate to $\mathrm{SO}_{2}$ and $\mathrm{CO}_{2}$. First, there are synergistic options that reduce both $\mathrm{SO}_{2}$ and $\mathrm{CO}_{2}$ emissions. These include fuel switching to high-Btu lower sulfur fuels, boiler repowering or greenfield, conservation, and altered dispatch. Unlike previous pollutants, the incremental control strategies for $\mathrm{SO}_{2}$ tend to result in increases in $\mathrm{CO}_{2}$, rather than neutrality, as observed with other pollutants. Options such as FGD and coal blending or fuel switching tend to result in greater levels of $\mathrm{CO}_{2}$.

Cofiring or fueling a boiler with natural gas or certain grades of foreign coal (i.e., Indonesian) that tend to have higher Btu contents than domestic coals results in lower $\mathrm{CO}_{2}$ emissions per $\mathrm{kWh}$ and lower sulfur emissions. Natural gas cofiring also has synergies of reducing trace metal HAPs and $\mathrm{NO}_{\mathrm{x}}$ emissions. Repowering or greenfield applications of clean coal technologies also provide significant control synergies with $\mathrm{SO}_{2}, \mathrm{NO}_{\mathrm{x}}, \mathrm{HAPs}$, and $\mathrm{CO}_{2}$. Table 4.1 indicates the relative efficiencies of selected clean coal technologies (CCTs) to a conventional pulyerized coal unit with an FGD unit (PC/FGD). The widespread commercial availability of these units is expected to occur after 1995 (South et al. 1990). Conservation has been frequently cited as a means of reducing $\mathrm{CO}_{2}$ emissions. Conservation can reduce generation requirements, which, in turn, reduce $\mathrm{CO}_{2}$ and $\mathrm{SO}_{2}$ emissions. In addition to utility-sponsored DSM programs, the increased prices due to carbon taxes, allowances, or standards will tend to reduce electricity demand, further reducing $\mathrm{CO}_{2}$ emissions. Finally, altered dispatch order has the potential to reduce the use of less-efficient, higher $\mathrm{CO}_{2}$ generating units in favor of more-efficient and lower emission generation.

The principal methods of Phase I compliance and Phase II compliance (NERC 1992) are FGD and switching from high-sulfur coal to blends of low-, medium-, and high-sulfur coals or wholesale switching to low-sulfur or compliance coals. Scrubbing, while effective in reducing $\mathrm{SO}_{2}$ emissions, along with certain $\mathrm{HAPs}$, requires energy from the host unit, consuming from 1-2\% of a unit's total generation. Greater energy requirements imply the burning of more coal per unit of electricity, leading to an increase in $\mathrm{CO}_{2}$ emissions. Fuel switching or blending may lower the average $r$ eating value of coal used, depending on the coal type used. Western coals tend to have lower heating values relative to eastern and midwestern coals (Watson 1992). While $\mathrm{SO}_{2}$ emissions are reduced by the use of lower sulfur coals, the lower heating value results in an increase in the amount of coal required to generate the same level of electricity. Again, the result is an increase in utility $\mathrm{CO}_{2}$ emissions.

The implications of the proposed bills to regulated GHGs and the eventual result of the NES's least-cost energy strategy (Section 1602) on utility compliance planning and growth are uncertain. The implementation of carbon taxes or increased efficiency standards on existing coal-fired power plants would certainly raise energy costs and be problematic for controls established for other pollutants (i.e., scrubbers for $\mathrm{SO}_{2}$ and overfire air for $\mathrm{NO}_{\mathrm{x}}$ ). An offsets system would alter new capacity choice and tend to encourage more lower and no-emission technologies (e.g., nuclear, renewable, natural gas, and conservation). The use 
TABLE 4.1 Percent Annual Emission Reduction from CCT Unit Compared to a PC/FGD Unit ${ }^{\text {a }}$

\begin{tabular}{cccc}
\hline CCT Type & $\begin{array}{c}\text { Atmospheric } \\
\text { Fluidized Bed }\end{array}$ & $\begin{array}{c}\text { Pressurized } \\
\text { Fluidized Bed }\end{array}$ & IGCC \\
\hline $\mathrm{CO}_{2}$ reduction & $2.3 \%$ & $10.6 \%$ & $19.9 \%$ \\
\hline
\end{tabular}

a See South et al. (1991).

of incentives for DSM and renewable technologies should encourage greater use of these technologies, although the effectiveness of these efforts to significantly reduce or stabilize $\mathrm{CO}_{2}$ emissions is uncertain, given predicted adoption rates.

\subsection{NEW UNIT SYNERGIES}

Titles I, III, and IV have been principally targeted at existing sources. New units will also be regulated under these titles and will, in addition, be regulated under NSPSs for $\mathrm{NO}_{\mathrm{x}}, \mathrm{SO}_{2}$, and $\mathrm{PM}_{10}$; nonattainment provisions for new sources; and new source standards in PSD areas (BACT and, potentially, visibility regulations). For Title IVs purposes, these units do not receive any allowance allocations and must meet Title IV's $\mathrm{NO}_{\mathrm{x}}$ performance standards.

From a compliance planning perspective, new units will either provide generation needed because of demand growth or provide replacement power for retiring units. In any case, the stricter BACT, likely to become more strict, will almost force certain control synergies. Increasing solid-waste disposal costs and possible $\mathrm{CO}_{2}$ regulation will also tend to force out those units that exhibit high levels of pollutants in any form. The effect of the new units will be twofold. First, their more efficient generation characteristics, combined with lower $\mathrm{SO}_{2}$ and $\mathrm{CO}_{2}$ emission rates, will make these units much higher in the dispatch order (relative to other older coal and oil baseload generation). Second, replacement units will serve as creators of emission offsets (in essence, allowance "generators"). Lower emission rates, combined with the same or higher generation levels, will free allowances for banking or sale.

\subsection{SUMMARY AND CONCLUSIONS}

Utility planning of Title IV compliance must consider the requirements of Title IV (holding $\mathrm{SO}_{2}$ allowances greater than or equal to utility system emissions and installing $\mathrm{NO}_{\mathrm{x}}$ control technologies to meet the requirements of the statute), market factors (fuel prices, technology costs, allowance prices, and wholesale electricity costs), regulatory treatment of 
compliance choices, and multiple and sometimes uncertain environmental regulations. Additional environmental planning considerations include the following:

- Title I NO $\mathrm{x}_{\mathrm{x}}$ planning,

- Solid and aqueous waste disposal,

- Potential control of HAPs, and

- Potential control of $\mathrm{CO}_{2}$.

Coordination will be the key to efficiency, but the Clean Air Act and state regulation provide no incentive to coordinate. Indeed, the inefficiency and uncertainty problems present planning dilemmas. Utility expenditures for controls that go beyond existing requirements may not be recoverable in rate base and may be challenged in prudence reviews, so a utility may be limited to recovering costs from only currently required emission standards. Typically, utility executives will be averse to taking the risk that control costs would be unrecoverable. Thus, so long as the possibility remains that utilities can avoid regulation, they will not plan or undertake coordination of all potential and current regulations. In consequence, utilities may be forced to commit to controls to meet near-term regulatory requirements. Such controls may be poorly suited to an integrated approach to meet all pollution control requirements.

The challenge of potential regulations and current planning requirements is further increased by technology-specific issues; for example, coal fuel-switching places utilities in a dilemma: to meet the provisions of one title may actually increase emissions of another substance, which would later become subject to regulation. For those $\mathrm{SO}_{2}$ control strategies that are adopted, but later become inappropriate due to altering regulation, utilities face several challenges. First, previous control choices may be ruled imprudent. Second, if the original strategy is costly to alter, a utility may be disadvantaged relative to its competitors. Third, the choice of the original strategy may make alterations to control a newly regulated pollutant highly difficult because of political, regulatory, economic, and technical factors.

To address the risks of choosing an inappropriate compliance plan, Phase I affected units have tended to choose flexible compliance strategies, including fuel trimming, fuel switching, and altered dispatch. Through these strategies, some risks may be mitigated. While possibly not the least-cost compliance plan to control regulated pollutants, a flexible strategy may be the loss-minimizing strategy. A loss-minimizing strategy can fail to capture control synergies, resulting in greater compliance costs and greater emission levels. The result is additional costs borne by society.

What Congress might have done for HAPs, in order to carry Section 112(n)(1) to its full intent, would have been so provide a mechanism to combine Titles I, III, and IV for planning purposes. In many cases, the most efficient way for utilities to meet Title III is to go ahead and install the level of control at the same time a unit installs controls for the other 
titles. $^{118}$ In the absence of such provisions in the Act, it is important for any regulations issued under Title III to allow utilities to integrate planning for the three titles, so the utilities may achieve the same efficiencies in Title III as are hoped to be achieved in Title IV.

For pollutants such as $\mathrm{CO}_{2}$ or stricter controls of $\mathrm{NO}_{\mathrm{x}}$ under a "Phase II" of Title I, planning is more difficult. While utility HAP emissions are under study, greenhouse gas policy and the effect of Title $\mathrm{I}$ on urban $\mathrm{O}_{3}$ are uncertain. Mechanisms to address these types of control uncertainties, while minimizing overall compliance costs, would be difficult to implement.

An early emission reduction program would allow utilities to be rewarded, rather than penalized, for early reductions of potentially regulated pollutants. $\Lambda$ program structured in this way would make it possible for utilities to make the reductions early, if that were the most cost-effective strategy. While only the contours of this idea have emerged, it has the potential to resolve the temporal mismatch and provide efficiency in control.

Assessing the control costs of one pollutant requires consideration of the direct costs associated with control of that pollutant and the indirect costs associated with controlling multiple pollutants. The central issue of cost evaluation is allocating common costs associated with the control of multiple pollutants. In some cases, a control technology will control multiple pollutants. In assessing the control costs of a particular strategy that controls multiple pollutants, one pollutant should not bear the entire cost of control. Another issue is the additional control costs incurred by a particular program increasing the control costs of other programs; for example, control of one pollutant may necessitate more expensive controls for other pollutants. In this case, the pollutant increasing the costs of compliance for other pollutants should bear the additional costs.

For purposes of benefit assessment, the synergistic control rffects of particular strategies must be examined. Several $\mathrm{SO}_{2}$ compliance options control multiple pollutants. In assessing the benefits (in terms of $\mathrm{SO}_{2}$ and $\mathrm{NO}_{\mathrm{x}}$ emission reduction), the benefits associated with reducing the emissions of other pollutarsis must also be considered.

Cost-effective utility compliance entails choosing those controls that minimize the total cost of compliance with all pollutants; however, regulatory barriers and control uncertainties make the choice of cost-effective compliance difficult. Under these conditions, flexibility is a key component of any utility compliance strategy. Assessment of the acid rain program must include the added costs imposed by a variety of control uncertainties. These added costs may be reduced by incentive mechanisms, such as early emission reduction

118 For example, in the lead phasedown program, the EPA was not sure of the level of control that was necessary and so adopted a graduated reduction program (i.e., in phases). 'This turned out to be the least efficient way of doing it, as it was not cost-effective for a refinery to add octane croacity gradually; rather, the most efficient way was to build the capacity all at once; but then, ot that point in time, there was not yet a market for the octane, so there were refineries with excess octane they could not sell and others with a shortage they could not afford to build on their own. The solution, of course, was to allow trading. 
programs; however, this incentive has not been forthcoming in the control programs for the utility industry. 


\section{REFERENCES}

Averch, H., and L. Johnson, 1962, Behavior of the Firm under Regulatory Constraint, American Economic Review 52:1052-1069.

Bailey, K.A., et al., 1993, Examination of Utility Phase I Compliance Choices and State Reactions to Title IV of the Clean Air Act Amendments of 1990, Argonne National Laboratory Technical Memo ANL/DIS/TM-2 (December).

Baron, D.P., and R.A. Taggart, 1977, A Model of Regulation under Uncertainty and a Test of Regulatory Bias, Bell Journal of Economics and Management Science (spring):151-167.

Bohi, D., and D. Burtraw, 1991, Avoiding Regulatory Gridlock in the Acid Rain Program, Journal of Policy Analysis and Management 10:676-684.

Bohi, D., and D. Burtraw, 1992, Utility Investment Behavior and the Emission Trading Market, Resources and Energy 14:129-153.

Cohen, S.D., et al., 1990, A Survey of State PUC Activities To Incorporate Environmental Externalities into Electric Utility Planning and Regulation, Lawrence Berkeley Laboratory Report LBL-28616 (May).

DOE, 1991, Limiting Net Greenhouse Gas Emissions in the United States, Department of Energy Report DOE/PE-0101 (September).

Dudeck, D., et al., 1990, $\mathrm{CO}_{2}$ and $\mathrm{SO}_{2}:$ Consistent Policy Making in a Greenhouse, Environmental Defense Fund, New York (December).

Electric Power Research Institute Journal, 1992, Comanagement of Low-and High-Volume Utility Wastes (September).

EPA: See U.S. Environmental Protection Agency.

EPRI: See Electric Power Research Institute Journal.

Farber, P.S., 1992, Selecting Systems To Control Emissions, Environmental Protection 3(10):10-11, 27-32.

Fish, A.L., and T.J. Elliott, 1992, A Comparison of Global Climate Change Legislation in the 102nd Congress, Argonne National Laboratory Internal Report (November).

Fish, A.L., and D.W. South, 1993, Global Climate Change: Actions and Policies of National Governments, Argonne National Laboratory Internal Report (June).

Geddes, R., 1992, A Historical Perspective on Electric Utility Regulation, Regulation (winter):75-82. 
Hahn, R., and G. Noll, 1983, Barriers to Implementing Tradeable Air Pollution Permits: Problems of Regulatory Institutions, Yale Journal of Regulation 1:63-91.

Hirst, E., and M. Schweitzer, 1989, Uncertainty: A Critical Element of Integrated Resource Planning, The Electricity Journal 2:16-27.

Kahn, A.E., 1988, The Economics of Regulation, MIT Press, Cambridge, Mass.

Krupnick, A.J., et al., 1992, The Social Costing Debate: Issues and Resolutions, Proceedings of the 2nd International Conference on the External Cost of Electric Power (September).

Laudal, D.L., et al., 1991, Enhanced Fine Particulate Control for Reduced Air-Toxic Emissions, remarks at the EPRI conference, Managing Hazardous Air Pollutants: State of the Art (November).

Loeb, A.P., and T.J. Elliott, in press, PSD Constraints on Utility Planning: A Review of Recent Visibility Litigation, Natural Resources Journal.

Makansi, J., 1991, Clean Air Act Amendments: The Engineering Response, Power Engineering 135(6):11-66.

McDermott, K.A., and D.W. South, 1990, Alternative Emission Cost Control Strateries for Electric Utilities: A Review, Argonne National Laboratory Internal Report (Decemiver).

McDermott, K.A., et al., 1993, Examination of Incentive Mechanisms for Innovative Technologies Applicable to Utility and Nonutility Power Generators, Argonne National Laboratory Report ANL/EAIS/TM-i02 (January).

Metzroth, L.F., and K.S. Knutson, 1991, Phase I and Phase II Acid Compliance Approaches: Compliance Planning Workshop, Kansas City (November).

Molburg, J., et al., 1991, Analysis of the Clean Air Act Amendments of 1990: A Forecast of the Electric Utility Industry Response to Title IV, Acid Deposi ‘ion Control, Argonne National Laboratory Report ANL/EAIS/TM-81 (October).

NAPAP, 1993, 1992 Report to Congress, National Acid Precipitation Assessment Program Report (June).

National Academy of Sciences, 1991, Policy Implications of Greenhouse Warming, National Academy of Sciences Report.

NERC, 1992, Reliability Assessment: 1992-2001, North American Electric Reliability Council (September).

Ottinger, R., et al., 1990, Environmental Costs of Electricity, Oceana Publications, New York, N.Y.

Radcliffe, P., 1992, FGD Economics, EPRI Journal 17(6):44-47. 
Ramaswamy, V., et al., 1992, Radiative Forcing of Climate from Halocarbon-Induced Global Stratospheric Ozone Loss, Nature 355:810-812.

Rittenhouse, R.C., 1992, Coal Wastes and Dates and More on Fly Ash, Power Engineering 96:10-15.

Rose, K., et al., 1992, Public Utility Commission Implementation of the Clean Air Act's Allowance Trading Program, National Regulatory Research Institute Report NRRI 92-6 (May).

Rupinskas, R.L., and P.A. Hiller, 1992, Switching to Low Sulfur Coal: Case Histories, Power Engineering 96(1):22-26.

Smith, D.J., 1991, Fluidized-bed Technology Probes Unit Size Limits, Power Engineering 95(12):18-23.

South, D.W., et al., 1990, Technologies and Other Measures for Controlling Emissions: Performance, Cost and Applicability, NAPAP SOS/T-25, in National Acid Precipitation Assessment Program, Acidic Deposition: State of Science and Technology, Volume IV, Washington D.C. (December).

South, D.W., et al., 1991, Coal Utilization and $\mathrm{CO}_{2}$ Emissions: What Are the Control Options?, in P.R. Dugan, D.R. Quigley, Y.A. Attia (eds.), Processing and Utilization of High Sulfur Coals IV: Proceedings of the Fourth International Conference on Processing and Utilization of High Sulfur Coals, Idaho Falls, Id., sponsored by the U.S. Department of Energy, et al., Elsevier Science Publishing Co. Inc., New York, N.Y.

South, D.W., et al., 1992a, Emissions Trading and Compliance: Regulatory Incentives and Barriers, Proceedings of the 1992 Air Emissions and Waste Management Conference, Lake Michigan States Section of the AWMA, Chicago, Ill. (January).

South, D.W., et al., 1992b, Synopsis and Preliminary Examination of State and Local Greenhouse Gas Programs and Proposals, Argonne National Laboratory Internal Report (April).

STAPPA/ALAPCO, 1992, Controlling Emissions of Nitrogen Oxides from Existing Utility Boilers under Title I of the Clean Air Act: Options and Recommendations, Report of the State and Territorial Air Pollution Program Administrators and the Association of Local Air Pollution Control Officials (April).

Szpunar, C.B., 1992, Air Toxic Emissions from the Combustion of Coal: Identifying and Quantifying Hazardous Air Pollutants from U.S. Coals, Argonne National Laboratory Report ANL/EAIS/TM-83 (Septe'^ber).

Taxon, T., et al., 1993, unpublished information, Argonne National Laboratory, Argonne, Ill. 

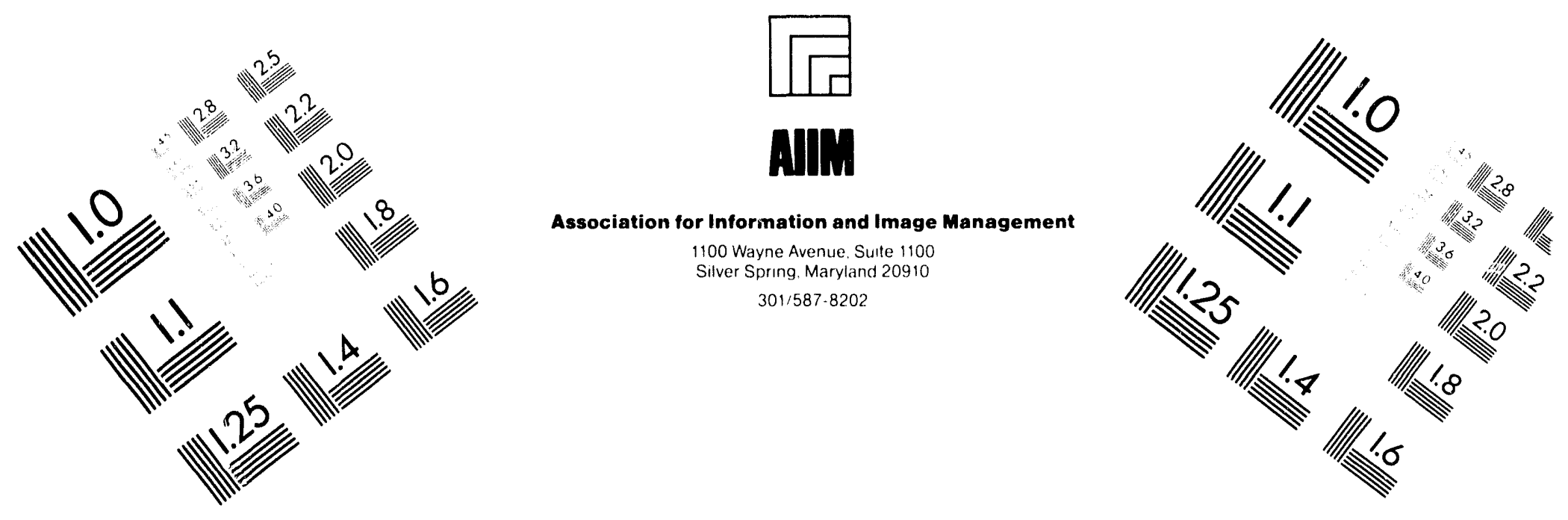

\section{Centimeter}

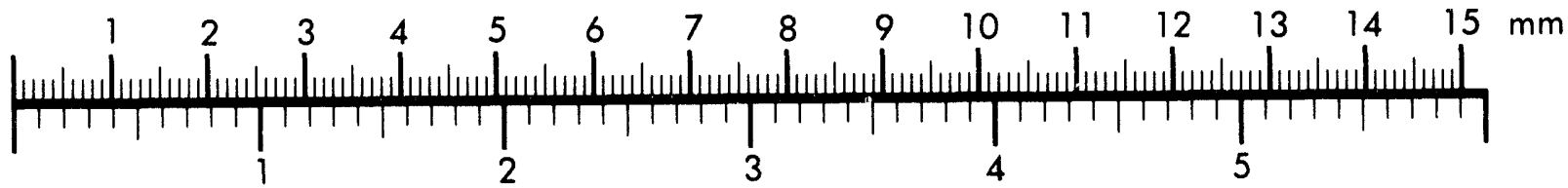
Inches
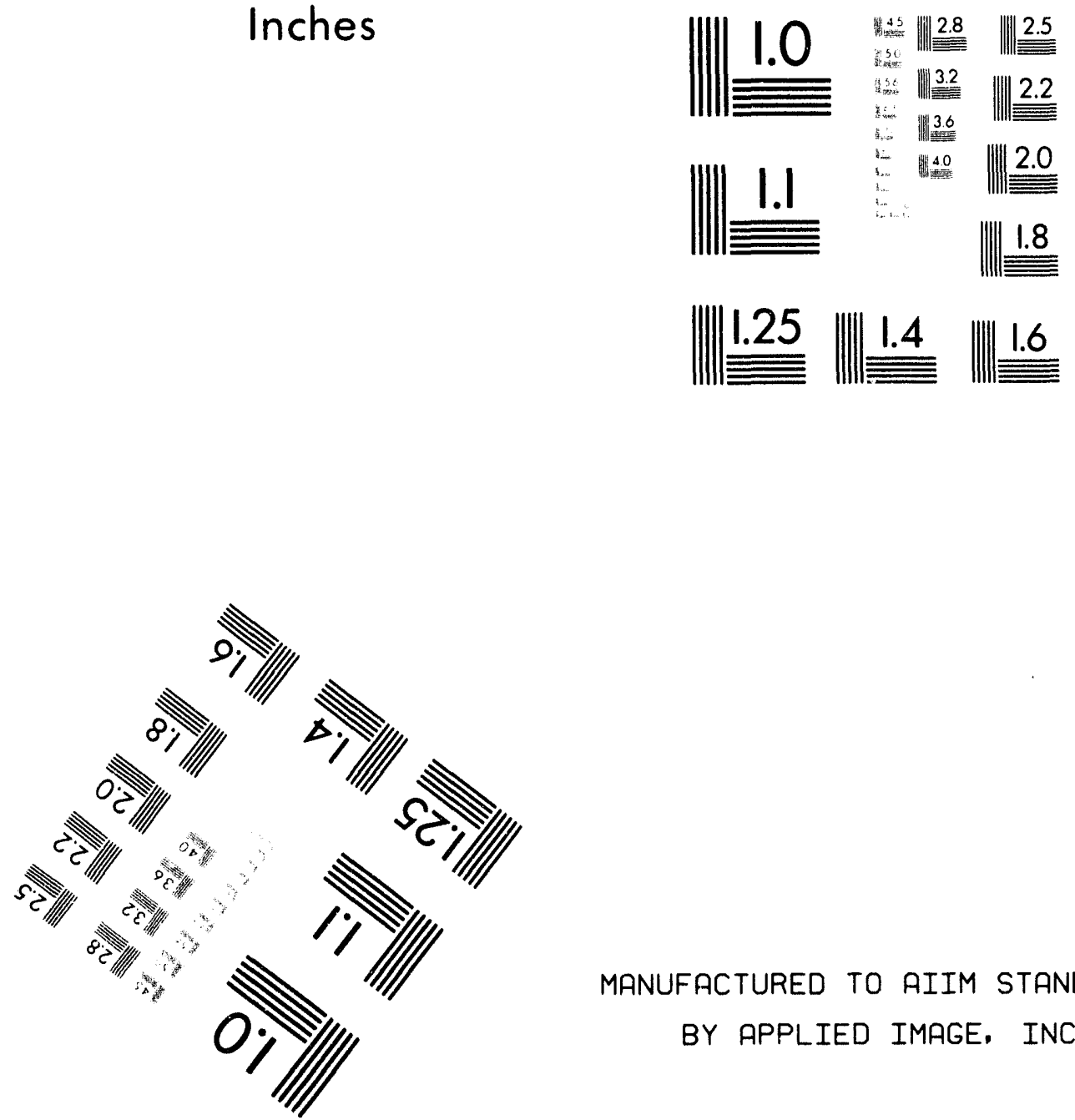

MANUFACTURED TO AIIM STANDARDS

BY APPLIED IMAGE, INC.

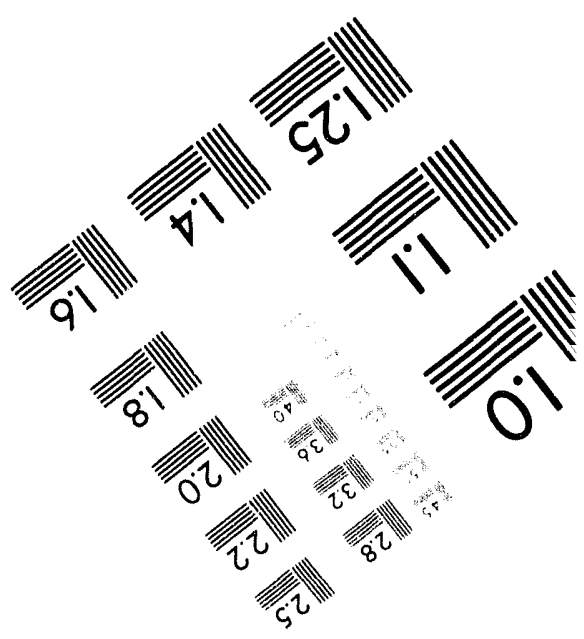



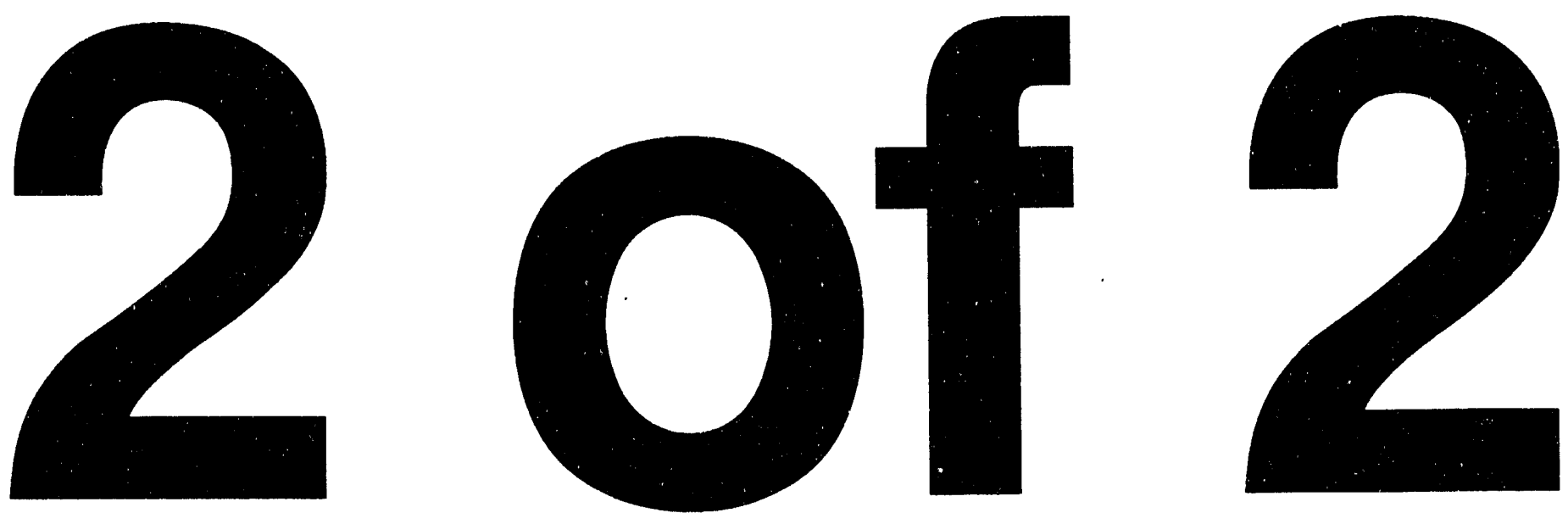
Taylor, A.S., 1992, Regulatory Accounting in Acid Rain Compliance Planning, Proceedings of the Electric Power Research Institute Clean Air Response: Emission Allowance Markets Workshop, St. Louis, Mo. (November).

Tietenberg, T.H., 1985, Emissions Trading: An Exercise in Reforming Pollution Policy, Resources for the Future, Washington, D.C.

U.S. Environmental Protection Agency, 1988, Wastes from the Combustion of Coal by Electric Utility Power Plants, EPA/530-SW-88-002 (February).

U.S. Environmental Protection Agency, 1991, National Air Quality and Emission Trends Report, 1990 (November), at 4-7.

Utility Environment Reporter, 1992, EPA Must Issue New Coal Ash Rules by 1994 under Court Approved Pact (July 10).

Utility Environment Reporter, 1993, Industry Pleased with EPA's Decision Regulating Coal Ash as Non-Hazardous (August 6).

van Horn, A., and T.A. Hewson, 1993, Integrated Analysis of Fuel, Technology and Emission Allowance Markets: Electric Utility Response to the Clean Air Act Amendments of 1990, Electric Power Research Institute Report TR-102510 (November).

Watson, J.F., 1992, Potential Impact of Compliance Systeriss on Electric Reliability, Proceedings of the Operating and Maintaining Systems for Clean Air Act Compliance Conference, Cincinnati, Ohio (June):

White, J.P., 1991, Utility Compliance Decisions: Assessing Risks and Uncertainty, presented to the Compliance and Emission Trading Strategies Facing the Acid Rain Trade-Offs Conference, Chicago, Ill. (June). 


\section{APPENDIX:}

SIGNIFICANT FEDERAL REGISTER NOTICES AFFECTING UTILITY EMISSIONS 


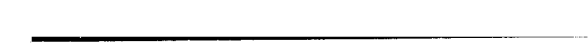


TABLE A.1 Significant Federal Register Notices Affecting Utility Emissions - Title IV $\mathrm{SO}_{2}$ and $\mathrm{NO}_{\mathrm{x}}$

Citation $\quad$ Type Subject $^{\mathrm{a}}$

56 Fed.Reg. 12529 (March 26, Notice 1991)

56 Fed.Reg. 21348 (May 8, 1991) Notice

56 Fed.Reg. 23744 (May 23, 1991)

56 Fed.Reg. 28891 (June 25, 1991)

Notice

Notice

56 Fed.Reg. 33278 (July 19, 1991)

56 Fed.Reg. 63002 (Dec. 3, 1991)

56 Fed.Reg. 65592 (Dec. 17, 1991)

56 Fed.Reg. 65608 (Dec. 17, 1991)

Notice

Proposed rule

Proposed rule

Proposed rule

Final rule

57 Fed.Reg. 29940 (July 7, 1992)
Guidance and form available for notification required under $\S 403(a)(1)$

(repowering extensions)

EPA intent to establish advisory committee on $\mathrm{NO}_{\mathrm{x}}$ from existing coal-fired boilers at utility plants under $\S 407$; request for comments

Regulations for conducting sales and auctions under $\S 416$; regulations allowing IPPs to obtain written guarantees of availability of allowances and direct sale

Guidance and form available for elections under $\S 406$ (bonus allowances for fossil-fuel-fired units in clean states)

National Allowance Data Base (version 2.0) available, allocating Phase II allowances

Regulations for permits, allowance system, continuous emissions monitoring, and excess emissions penalties

Regulations for conducting sales and auctions under $\S 416$; regulations allowing IPPs to obtain written guarantees of availability of allowances and direct sale

Notice of EPA intent to request proposals for delegation of the administration of auctions and direct sale under $\S 416$; request for proposals and public comment
List of initial allocations of allowances for Phase I and Phase II; regulations regarding three allowance reserves (extensions, conservation, and renewable energy) and reserve for auctions and sales; set-aside for additional allowances under $\S 409$; procedures for small diesel refineries under $\S 410(h)$; revision of permits rule; and criteria for exempting QFs and IPPs from Title IV 
TABLE A.1 (Cont.)

\begin{tabular}{|c|c|c|}
\hline Citation & Type & Subject $^{\mathrm{a}}$ \\
\hline 57 Fed.Reg. 30034 (July 7, 1992) & Notice & $\begin{array}{l}\text { Final National Allowance Data Base } \\
\text { (version 2.1) available, allocating } \\
\text { Phase II allowances; other data files } \\
\text { available }\end{array}$ \\
\hline 57 Fed.Reg. 46167 (Oct. 7, 1992) & Notice & $\begin{array}{l}\text { Delegation of authority for auctions and } \\
\text { sales to CBOT pursuant to } \S 416(f)\end{array}$ \\
\hline 57 Fed.Reg. 55632 (Nov. 25, 1992) & Proposed rule & $\begin{array}{l}\text { Regulations establishing } \mathrm{NO}_{\mathrm{x}} \text { emission } \\
\text { limitations under } \S 407\end{array}$ \\
\hline 57 Fed.Reg. 61489 (Dec. 24, 1992) & Corrections & $\begin{array}{l}\text { Regulations establishing } \mathrm{NO}_{\mathrm{x}} \text { emission } \\
\text { limitations under } \S 407\end{array}$ \\
\hline 58 Fed.Reg. 3590 (Jan. 11, 1993) & Final rule & $\begin{array}{l}\text { General provisions and permits, } \\
\text { allowance system, continuous emissions } \\
\text { monitoring, excess emissions, and } \\
\text { administrative appeals }\end{array}$ \\
\hline
\end{tabular}

a CBOT, Chicago Board of Trade; IPP, independent power producer; and QF, qualifying facility. 
TABLE A.2 Significant Federal Register Notices Affecting Utility Emissions - Title $\mathrm{I} \mathrm{SO}_{2}$ and $\mathrm{NO}_{\mathrm{x}}$

\begin{tabular}{|c|c|c|}
\hline Citation & Type & Subject $^{\mathrm{a}}$ \\
\hline $\begin{array}{l}56 \text { Fed.Reg. } 27257 \\
\text { (June 13, 1991) }\end{array}$ & Notice & $\begin{array}{l}\text { Availability of working draft of General } \\
\text { Preamble for Title I }\end{array}$ \\
\hline $\begin{array}{l}56 \text { Fed.Reg. } 27630 \\
\text { (June } 14,1991 \text { ) }\end{array}$ & Proposed rule & $\begin{array}{l}\text { Regulations adopting NSR exclusion for utility } \\
\text { pollution control projects (the WEPCO issue) }\end{array}$ \\
\hline $\begin{array}{l}56 \text { Fed.Reg. } 56694 \\
\text { (Nov. } 6,1991 \text { ) }\end{array}$ & Final rule & $\begin{array}{l}\text { Designation of attainment status and } \\
\text { classifications for selected areas for NAAQSs }\end{array}$ \\
\hline $\begin{array}{l}57 \text { Fed.Reg. } 8120 \\
\text { (March 6, 1992) }\end{array}$ & Notice & $\begin{array}{l}\text { Extension of public comment period for } \mathrm{NO}_{\mathrm{x}} \\
\text { criteria document }\end{array}$ \\
\hline $\begin{array}{l}57 \text { Fed.Reg. } 13498 \\
\text { (April 16, 1992) }\end{array}$ & Proposed rule & General Preamble for Title I \\
\hline $\begin{array}{l}57 \text { Fed.Reg. } 18070 \\
\text { (April 28, 1992) }\end{array}$ & Proposed rule & Appendixes to the General Preamble \\
\hline $\begin{array}{l}57 \text { Fed.Reg. } 32314 \\
\text { (July 21, 1992) }\end{array}$ & Final rule & $\begin{array}{l}\text { Regulations adopting NSR exclusion for utility } \\
\text { pollution control projects (the WEPCO issue) }\end{array}$ \\
\hline $\begin{array}{l}57 \text { Fed.Reg. } 35542 \\
\text { (Aug. 10, 1992) }\end{array}$ & $\begin{array}{l}\text { Proposed } \\
\text { decision }\end{array}$ & $\begin{array}{l}\text { EPA decision that revisions of the primary } \\
\text { and secondary standards for } \mathrm{O}_{3} \text { are not } \\
\text { appropriate at this time }\end{array}$ \\
\hline $\begin{array}{l}57 \text { Fed.Reg. } 44375 \\
\text { (Sept. 25, 1992) }\end{array}$ & Notice & $\begin{array}{l}\text { Proposed consent decree for settlement of citizen } \\
\text { suit brought by EDF to compel EPA to review } \\
\text { and revise NAAQS for } \mathrm{SO}_{2} \text {; decree would } \\
\text { require EPA to take final action by } 4 / 15 / 93 \text { on } \\
\text { pending secondary standards }\end{array}$ \\
\hline $\begin{array}{l}57 \text { Fed.Reg. } 55620 \\
\text { (Nov. 25, 1992) }\end{array}$ & Guidance & $\begin{array}{l}\text { Supplement to General Preamble regarding } \mathrm{NO}_{\mathrm{x}} \\
\mathrm{RACT} \text {, NSR, interaction of Titles } \mathrm{I} \text { and } \mathrm{IV}, \mathrm{O}_{3} \\
\text { transport, and } \S \S 185 \mathrm{~B} \text { and } 182(\mathrm{f})\end{array}$ \\
\hline
\end{tabular}

a NSR, New source review. 
TABLE A.3 Significant Federal Register Notices Affecting Utility Air Emissions - Title III

\begin{tabular}{|c|c|c|}
\hline Citation & Type & Subject \\
\hline $\begin{array}{l}56 \text { Fed.Reg. 28548 } \\
\text { (June 21, 1991) }\end{array}$ & Notice & $\begin{array}{l}\text { Availability of preliminary draft of the list of } \\
\text { categories and subcategories required under } \\
\S 112 \text { (c) }\end{array}$ \\
\hline $\begin{array}{l}56 \text { Fed.Reg. } 63798 \\
\text { (Dec. } 5,1991)\end{array}$ & Notice & $\begin{array}{l}\text { Issuance of final amended guidelines for } \\
\text { assessing the risks for developmental toxicity } \\
\text { from exposure to environmental agents and } \\
\text { the scientific basis }\end{array}$ \\
\hline $\begin{array}{l}57 \text { Fed.Reg. 22888 } \\
\text { (May 29, 1992) }\end{array}$ & Notice & $\begin{array}{l}\text { Issuance of final "Guidelines for Exposure } \\
\text { Assessment," superseding "Guidelines for } \\
\text { Estimating Exposures" published Sept. 24, } \\
1986\end{array}$ \\
\hline $\begin{array}{l}\text { 57 Fed.Reg. 24152 } \\
\text { (June 5, 1992) }\end{array}$ & Notice & $\begin{array}{l}\text { Request for comments on draft report, "A } \\
\text { Cross-Species Scaling Factor for Carcinogen } \\
\text { Risk Assessment" }\end{array}$ \\
\hline $\begin{array}{l}57 \text { Fed.Reg. } 31576 \\
\text { (July 16, 1992) }\end{array}$ & Notice & $\begin{array}{l}\text { Initial list of categories of major and area } \\
\text { sources of HAPs as required by } \S 112(c)(1)\end{array}$ \\
\hline $\begin{array}{l}57 \text { Fed.Reg. } 44147 \\
\text { (Sept. 24, 1992) }\end{array}$ & Notice & $\begin{array}{l}\text { Draft schedule for the promulgation of } \\
\text { emission standards required under } \S 112(e)\end{array}$ \\
\hline
\end{tabular}



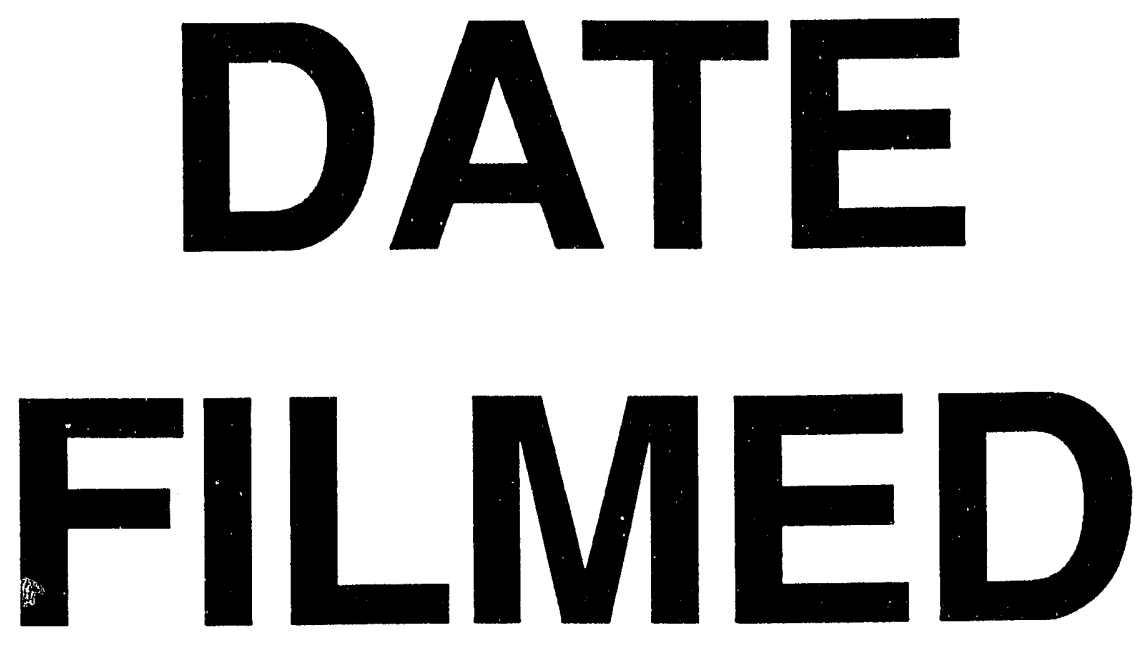

$6 / 17 / 94$
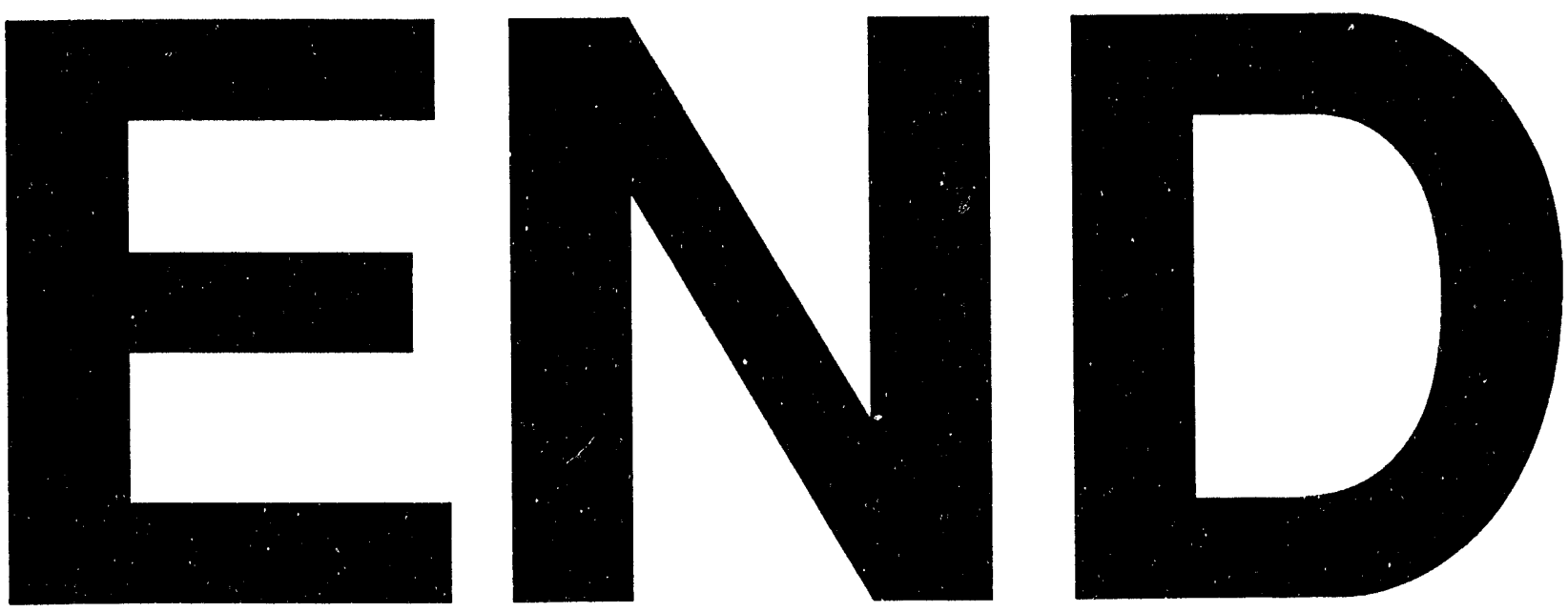
